\title{
CORRELAÇÕES GENÉTICAS E FENOTÍPICAS ENTRE PRODUÇÃO DE GRÃOS, TEOR DE PROTEINA E TEOR DE ÓLEO EM SOJA, EM VÁRIOS AMBIENTES
}

RUBENS MARSCHALEK

Engenheiro Agrônomo

Orientador: Prof. Dr. ISAÍAS OLÍVIO GERALDI

Dissertação apresentada à Escola Superior de Agricultura " Luiz de Queiroz ", da Universidade de São Paulo, para obtenção do título de Mestre em Agronomia, Área de concentração: Genética e Melhoramento de Plantas.

PIRACICABA

Estado de São Paulo - Brasil

Janeiro - 1995 
Fichá catalografica freparada pela Fegar de livros da

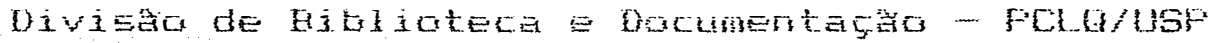

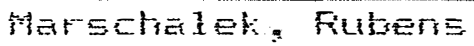

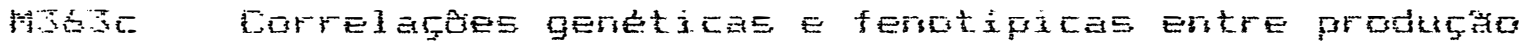

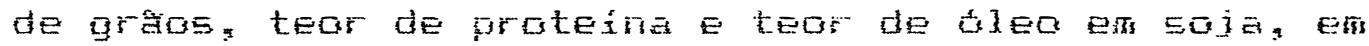

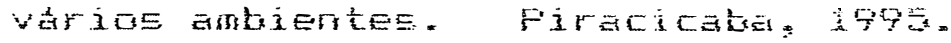
1630 .

Dise- (WEStFE\} - EGALQ

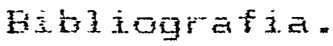

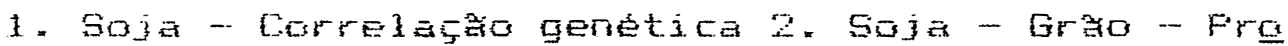

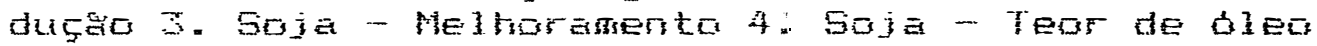

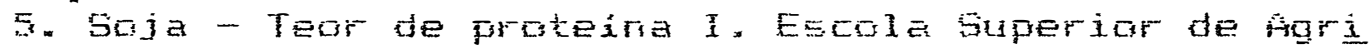

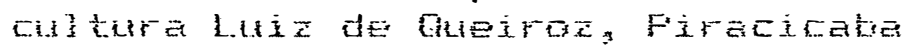

CDD $\quad 63 \times 34$ 


\section{CORRELAÇÕES GENÉTICAS E FENOTÍPICAS ENTRE PRODUÇÃO DE GRÃOS, TEOR DE PROTEINA E TEOR DE ÓLEO EM SOJA, EM VÁRIOS AMBIENTES}

RUBENS MARSCHALEK

Aprovada em: 06.03.1995

Comissão julgadora:

Prof. Dr. Isaias Olivio Geraldi ESALQ/USP

Prof. Dr. Claudio Lopes de Souza Júnior ESALQ/USP

Dr. Luciano Lourenço Nass EMBRAPA

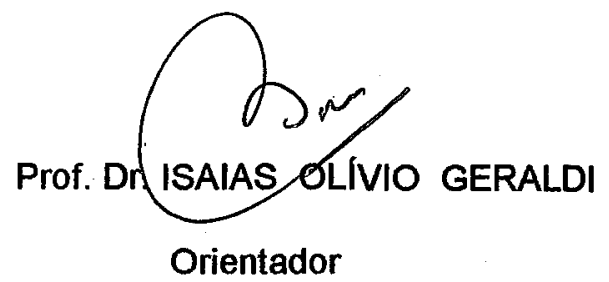




\section{AGRADECIMENTOS}

O autor agradece a todas as pessoas que colaboraram na realização desta pesquisa, em especial:

- Ao Prof. Dr. Isaias Olívio Geraldi, pela orientação, conhecimentos transmitidos, apoio, estímulo e amizade durante o curso e na elaboração deste trabalho.

- Ao Prof. Dr. Claudio Lopes de Souza Júnior, pelos conhecimentos transmitidos e pela atenção dispensada durante a ausência do orientador.

- Aos docentes do Departamento de Genética da ESALQ/USP, pelos ensinamentos recebidos durante 0 curso.

- À Coordenação de Aperfeiçoamento de Pessoal de Nivel Superior ( CAPES ), pela concessão da bolsa de estudos.

- Ao amigo Nelson da Silva Fonseca Júnior, pelo grande apoio na análise estatística dos dados, amizade e conhecimentos transmitidos.

- À Empresa de Pesquisa Agropecuária e Extensão Rural de Santa Catarina S.A. (EPAGRI S.A.) pela concessão de licença para cursar o mestrado.

- Ao Prof. Dr. Natal Antônio Vello e equipe, pelo apoio à este programa de pesquisa durante o afastamento do orientador. 
- Aos colegas Regina Lúcia Ferreira Gomes, Paulo Sérgio Koch, Raimundo Nonato Vieira da Cunha, e Luis Claudio Prado, pela amizade, estímulo e troca de conhecimentos.

- Ao Prof. M.Sc. Egon José Schramm, Vice-Reitor da Universidade Regional de Blumenau ( FURB ), meu primeiro mestre na ciência da genética, durante o curso técnico de agropecuária.

- Ao Prof. João Joaquim Fronza ( in memorian ), ex-reitor da Universidade Regional de Blumenau, pelo exemplo, conhecimentos e lições de vida transmitidos.

- Ao Prof. Juarez Gabardo, da Universidade Federal do Paraná, que durante o curso de agronomia, através de suas brilhantes aulas de genética vegetal, concretizaram em mim a certeza de que meus caminhos haveriam de trilhar os campos da genética e melhoramento vegetal.

- Aos funcionários da Divisão de Biblioteca e Documentação, em especial às bibliotecárias Silvana Marchizelli Gregório, Eliana Maria Garcia Sabino, Kátia Maria Andrade Ferraz e à funcionária Aparecida Elizabeth dos Santos da Silva, pelo profissionalismo e amizade durante o curso.

- À secretária da pós-graduação do Departamento de Genética da ESALQ, Candida Vanderléia de Oliveira, pelo tratamento cordial e atenção dispensada durante todo o curso.

- Aos funcionários do Setor de Genética Aplicada às Espécies Autógamas da ESALQ, pela colaboração na condução dos trabalhos experimentais. 
- Aos funcionários do Laboratório de Genética Fisiológica da ESALQ, pela realização das análises químicas das parcelas experimentais.

- À todos os meus familiares; em especial à meus avós maternos, Gustav Ausgust Isleb ( in memorian ) e Herta Isleb; e paternos, Erich Marschalek e Ema Marschalek, dos quais aprendi o amor à Deus, à vida, e à natureza. 
À meus pais Heinz e Edeltraud

e minhas irmãs Ruth e Irene

OFEREÇO

A glória dos filhos são seus pais.

Provérbios 17:6b

No Princípio criou Deus os céus e a terra.

Gênesis 1:1

À Julia, minha esposa

DEDICO

Deixa-me ver tua face, deixa-me ouvir tua voz, pois tua face é tão formosa e tão doce a tua voz ! 


\section{SUMÁRIO}

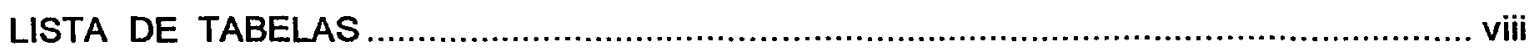

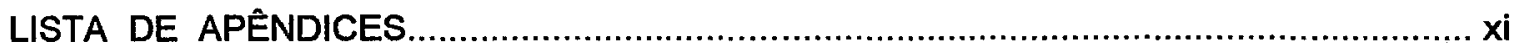

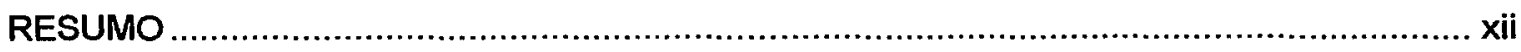

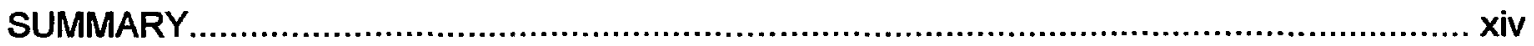

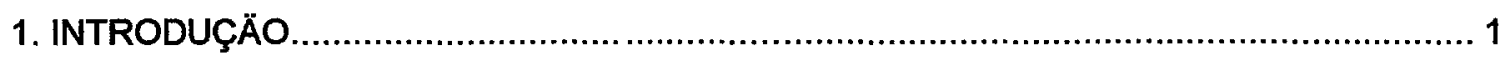

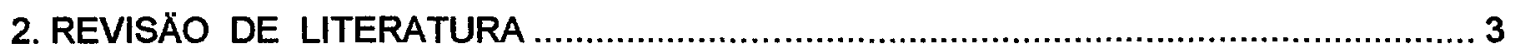

2.1 Taxonomia, Origem e Domesticaçäo da Soja e Histórico ...................................... 3

2.2 Produçäo Mundial de Soja ( óleo e farelo ) e sua Importância Econômica ................... 8

2.3 Variaçöes no Teor de Óleo e Proteína ................................................................... 11

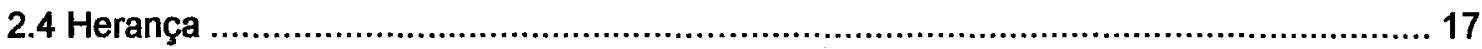

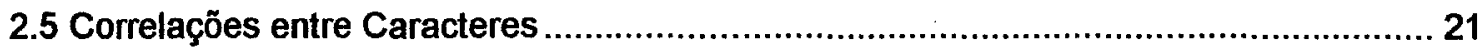

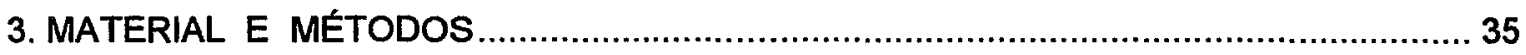

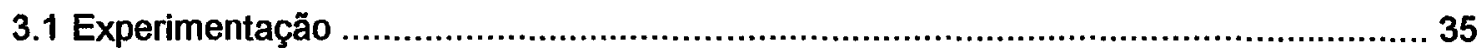

3.2 Análises da Variância e Estimativas de seus Componentes................................... 37

3.3 Estimativas das Variâncias e Covariâncias Genéticas ..................................... 43

3.4 Estimativas dos Coeficientes de Determinação Genotípicos (b ), das Correlações

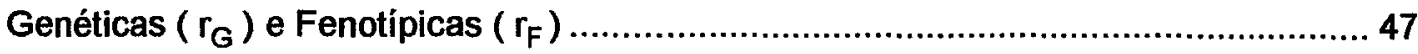

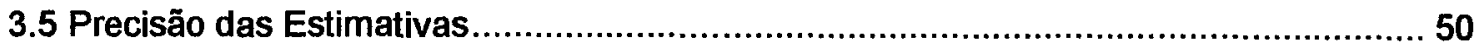


4. RESULTADOS E DISCUSSÃO

4.1 Análise geral dos dados: Produção de Grãos (PG ), Teor de Óeo ( TO ) e Teor de Proteina ( TP ) 52

4.2 Análises de Variância 54

4.3 Caracterização dos Ambientes 59

4.4 As Estimativas das Variâncias 62

4.5 Coeficiente de Determinação Genotípico. 64

4.6 Associação entre Caracteres 68

5. CONSIDERAÇÕES FINAIS

6. CONCLUSÕES 77

7. REFERÊNCIAS BIBLIOGRÁFICAS 79

TABELAS 91

APENNDICES 100 


\section{LISTA DE TABELAS}

Tabela 1 Distribuição das espécies do gênero Glycine Willd, número básico de cromossomos das espécies, símbolo genômico e centro de origem de cada espécie, segundo KENWORTHY (1989).

Tabela 2 Produção mundial de soja nas safras 1992/93 e 1993/94 (em milhões de toneladas)

Tabela 3 Esquema de análise de variância individual para cada ambiente

Tabela 4 Esquema de análise de variância conjunta para os vários ambientes, considerando-se genótipos como efeito fixo e ambientes como efeito aleatório ( modelo misto)

Tabela 5 Esquema de análise de variância conjunta para combinações envolvendo o ambiente 2, onde considera-se genótipos e ambientes como efeitos fixos ( modelo fixo ) 
Tabela 6 Médias de duas repetições de 30 genótipos avaliados em 4 ambientes para os caracteres produção de grãos ( PG; gramas/parcela ), teor de óleo ( TO; \% ), teor de proteína ( TP; \% ), e produção de proteína ( PP; Kg/ha ).

Tabela 7 Análises de variância individuais com quadrados médios, médias e coeficientes de variação nos 4 ambientes para o caráter produção de grãos ( $P G$ ).

Tabela 8 Análises de variância individuais com quadrados médios, médias e coeficientes de variação nos 4 ambientes para o caráter teor de óleo ( TO ) e teor de proteína (TP).

Tabela 9 Graus de liberdade e quadrados médios das ANAVAS individuais e conjuntas para os 3 caracteres nos 4 ambientes.

Tabela 10 Variância genética $\left(V_{t}\right)$ e ambiental $\left(V_{e}\right)$, respectivos desvios e coeficientes de variação.

Tabela 11 Coeficiente de determinação genotípico (b), e seu respectivo desvio, em valor absoluto e em porcentagem ( CV ). 
Tabela 12 Covariâncias genéticas entre ambientes envolvendo teor de óleo ( \% ) 84/85 produção de grãos ( g/parcela ) 86/87 .

98

Tabela 13 Covariâncias e correlações genéticas entre ambientes envolvendo teor de óleo (\% ) $84 / 85$ e teor de proteína ( $\%$ ) 86/87.

Tabela 14 Covariâncias e correlações genéticas entre ambientes envolvendo produção de grãos ( g/parcela ) 84/85 e teor de proteína ( \% ) 86/87. 


\section{LISTA DE APÊNDICES}

Apêndice 1 Variância da interação tratamentos $x$ ambientes nas análises de variância conjuntas.

Apêndice 2 Correlações genéticas entre ambientes para o mesmo caráter produção de grãos ( ao nivel de médias de tratamentos ) ( diagonal superior), e para o caráter teor de óleo ( diagonal inferior ).

Apêndice 3 Médias de 2 repetições de $30^{\circ}$ genótipos avaliados em quatro ambientes para os caracteres produção de grãos ( PG; Kg/ha ), teor de óleo ( TO; \% ), teor de proteina ( TP; \% ), e produção de proteina ( PP; Kg/ha ).

Apêndice 4 Correlações encontradas na literatura entre produção de grãos, teor de óleo e teor de proteina em soja. 


\section{CORRELAÇõES GENÉticAs E FENOTÍPICAS ENTRE PRODUÇÃo DE GRÃOS, TEOR DE PROTEINA E TEOR DE ÓLEO EM SOJA, EM VÁRIOS AMBIENTES}

Autor: RUBENS MARSCHALEK

Orientador: Prof. Dr. ISAIAS OLIVIO GERALDI

\section{RESUMO}

Para o melhoramento conjunto de vários caracteres torna-se importante o conhecimento das correlações genéticas e fenotípicas entre eles, no sentido de se direcionar o programa de forma mais eficiente para a seleção de genótipos superiores. Normalmente as correlações são estimadas a partir de experimentos em somente um ambiente. Tais estimativas são frequentemente muito discrepantes, devido muitas vezes à influência de componentes da interação genótipo por ambiente nas estimativas de variâncias e covariâncias.

O objetivo deste trabalho foi a estimação das correlações genéticas e fenotípicas entre os caracteres produção de grãos, teor de proteína e teor de óleo em soja [ Glycine max ( L. ) Merrill ], a partir da avaliação experimental de 30 genótipos em quatro ambientes, correspondentes a diferentes locais e anos. Para a avaliação experimental foram 
utilizados delineamentos em blocos ao acaso com duas repetições por experimento. A parcela foi constituida de 4 linhas de $5,00 \mathrm{~m}$ de comprimento espaçadas de 0,60 m. Para a tomada de dados utilizou-se apenas as duas linhas centrais, eliminando-se $0,50 \mathrm{~m}$ em cada extremidade, de modo que a parcela útil ficou constituída de duas linhas de 4,00 m.

O coeficiente de determinação genotípico ( b ) foi relativamente alto para a produção de grãos ( da ordem de $60 \%$ ), bem como para o teor de proteina ( $67 \%$ ) e bastante alto para o teor de óleo ( da ordem de $90 \%$ ). Estes valores são mais altos do que aqueles normalmente encontrados na literatura e devem-se provavelmente à maior discrepância entre os tratamentos, causada pela sua origem, isto é, variedades e linhagens experimentais, que não correspondem à genótipos extraídos ao acaso de uma população.

As estimativas das correlações genéticas indicam que produção de grãos e teor de óleo são positivamente correlacionados $\left(\vec{r}_{G}=+0,33\right)$, enquanto que produção de grãos e teor de proteína são negativamente correlacionados $\left(\bar{r}_{G}=-0,47\right)$, assim como teor de óleo e teor de proteína ( $\bar{r}_{G}=-0,31$ ). Estes resultados são concordantes com a maioria da literatura, e indicam que a seleção baseada somente no teor de proteína irá acarretar reduções na produção de grãos e teor de óleo. Verificou-se também que as estimativas acima, obtidas a partir de análises conjuntas de vários experimentos foram mais consistentes, o que reflete a importância da estimação de variâncias e covariâncias genéticas isentas dos componentes de interação com ambientes. 


\title{
GENETIC AND PHENOTYPIC CORRELATIONS AMONG SEED YIELD, PROTEIN CONTENT AND OIL CONTENT IN SOYBEANS, IN SEVERAL ENVIRONMENTS
}

\author{
Author: RUBENS MARSCHALEK
}

Adviser : Prof. Dr. ISAIAS OLÍVIO GERALDI

\section{SUMMARY}

The success of a breeding program for several traits depends on the knowledge of the genetic and phenotypic correlations between the traits. Usually these correlations are estimated from the analysis of variance and covariance of the traits evaluated in one environment. Such estimates generally have some bias due to the genotype by environment interaction components of variance and covariance.

The objective of this work was the estimation of the genetic and phenotypic correlations, based on the evaluation of 30 soybean genotypes [ Glycine max ( L. ) Merrill ] in four environments ( differents locations or years ) for seed yield, protein content and oil content. A randomized block design with two replications was employed for all experiments. Plots 
consisted of four 5.00 meter long rows spaced 0.60 meter apart. For the evaluation, the two central lines were considered.

The coefficient of genotypic determination ( $b$ ) was relatively high for seed yield ( $60 \%$ on the average ), as well as for protein content ( $67 \%$ ), and very high for oil content ( $90 \%$ on the average ). These coefficients are higher than most reported, and are probably a result of the origin of the treatments, i. e., these are varieties and experimental lines, and do not refers to a random sample of genotypes from a population.

Estimates of genetic correlations indicated that seed yield and oil content are positively correlated $\left(\bar{r}_{G}=+0.33\right)$ while seed yield and protein content are negatively correlated $\left(\bar{r}_{G}=-0.47\right)$, as well as oil content and protein content $\left(\bar{r}_{G}=-0.31\right)$. These results are in agreement with most of those reported and indicates that selection toward the increase of protein content will decrease seed yield and oil content. General results indicated that estimates of genetic and phenotypic correlations based on evaluation in several environments are more consistent than those based on one environment only, showing the importance of the estimation of genetic variance and covariances without the components of the genotype by environment interaction. 


\section{INTRODUÇÃO :}

A soja [ Glycine $\max$ ( L. ) Merrill ] é a mais importante fonte vegetal comestivel de óleo e de proteína no mundo atualmente. É uma das culturas que sofreu maior expansão de cultivo no mundo, uma vez que apresenta uma boa produtividade de grãos, normalmente acima das 2 toneladas por hectare, e devido à composição química dos grãos, que têm em média $20 \%$ do seu peso em óleo e $40 \%$ em proteína, é a cultura que mais produz proteína por unidade de área.

Muitos esforços sempre foram feitos atravès do melhoramento genético, no sentido de aumentar a produtividade. Assim sendo, os caracteres relacionados com a produtividade sempre tiveram atenção especial, além de outros relacionados à aspectos agronômicos. No entanto, outros caracteres, relacionados com a constituição química dos grãos não foram significativamente pesquisados, de modo que, qualidade do óleo, além do teor e qualidade da proteína, têm permanecido praticamente inalterados nos cultivares de soja lançados nos últimos 50 anos ( WILCOX, 1989 ), embora tenham ocorrido certos acréscimos no teor de óleo, visto que este caráter tem correlação positiva com a produção de grãos.

Hoje, estamos a ponto de ter cultivares melhorados para teor e qualidade destes dois constituintes ( WILCOX, 1989 ), mesmo porque isto já se faz necessário, uma vez que o mercado caminha rumo à realização de transações onde lotes de grãos com melhor composição química são nitidamente privilegiados, em detrimento de outros. Parece provável, 
num curto a médio prazo, que o mercado mundial venha a proporcionar preços diferenciados aos lotes de soja de acordo com a composição química do grão ( HURBURGH et alii, 1990).

A qualidade do óleo tem sido melhorada através do desenvolvimento de mutantes com composição alterada dos ácidos graxos e incorporação de genes. $O$ valor nutricional do farelo de soja tem sido melhorado por meio da eliminação dos inibidores da tripsina, e os produtos alimentíceos têm sido melhorados pela eliminação de enzimas lipoxigenases específicas. Essas mudanças, segundo WILCOX ( 1989 ), permitirão o uso cada vez mais amplo dos produtos derivados da soja.

Quanto aos teores de óleo e proteina, os melhoristas têm ciência da importância destes dois caracteres e da associação, usualmente negativa entre os dois, o que obviamente dificulta o melhoramento, principalmente para proteína, que é negativamente correlacionada à produção de grãos. Assim, os objetivos deste trabalho são:

Estudar o tipo e o grau de associação existentes entre produção de grãos, teor de óleo e teor de proteína em vários ambientes, estudando-se portanto as correlações genéticas e fenotípicas entre estes caracteres, além de estabelecer o coeficiente de determinação genotipico para os mesmos. 


\section{REVISÃo DE LITERATURA}

\section{1 - Taxonomia, Origem, Domesticação da Soja e Histórico}

A soja cultivada [ Glycine max (L.) Merrill ] é um membro da família Leguminosae, subfamília Papilionoideae, tribo Phaseoleae. Esta tribo é a mais importante, economicamente, na família. A tribo Phaseoleae contém ainda outros gêneros de importância econômica além do gênero Glycine, sendo eles : Lablab, Cajanus, Phaseolus, Psophocarpus e Vigna ( HYMOWITZ \& SINGH, 1987 ). A história taxonômica do gênero Glycine é entremeada por dúvidas e confusões. Atualmente o gênero encontra-se dividido em dois subgêneros : Glycine e Soja. KENWORTHY ( 1989 ) apresenta ( Tabela 1 ) a distribuição das espécies de cada subgênero, o número básico de cromossomos das espécies, o símbolo genômico e o centro de origem.

As espécies pertencentes ao subgênero Glycine são perenes e distribuem-se na Austrália e ilhas do sul do pacifico, Filipinas, Taiwan e sudeste da China. Nenhuma destas espécies, ao que tudo indica, teria sido extensivamente usada na agricultura ( HADLEY \& HYMOWITZ, 1973 ) mas atualmente são consideradas como importante fonte de genes ( KENWORTHY, 1989 ). 
Tabela 1 - Distribuição das espécies do gênero Glycine Willd, número básico de cromossomos das espécies, símbolo genômico e centro de origem de cada espécie, segundo KENWORTHY (1989) .

\begin{tabular}{|c|c|c|}
\hline Espécies & $\begin{array}{l}\text { No } \\
\text { crom. }\end{array}$ & $\begin{array}{l}\text { Simb. } \\
\text { Gen. }\end{array}$ \\
\hline
\end{tabular}

Subgênero Soja ( Moench ) F.J. Herm.
G. $\max ($ L.) Merr.
40
GG
Cultivada
G. soja Sieb. \& Zucc.
40
GG
China,Taiwan, Japan

\section{Subgênero Glycine}

\begin{tabular}{|c|c|c|c|}
\hline Garenaria Tind & 10 & . & \\
\hline G.arenaria Tind & 40 & (n) & E.Kimberley,Australia \\
\hline G. canescens F J.Herm & 40 & A2A2 & S.Q1d coast Australia \\
\hline G. clandestina Wendl. & 40 & A1A1 & N.E. \& S.E. Australia \\
\hline G. curvata Tind. & 40 & --- & Cape York, Australia \\
\hline G. cyrtoloba Tind. & 40 & CC & N.E. Australia \\
\hline $\begin{array}{l}\text { G. falcata Benth } \\
\text { G. latifolia } \\
\text { Newell \& }\end{array}$ & 40 & FF & N. Territory, Australia \\
\hline Hymowitz & 40 & B1B1 & N.E. Australia \\
\hline G. latrobeana (Meissn.) & & & \\
\hline $\begin{array}{ll} & \text { Benth. } \\
\text { G. microphylla } & \text { (Benth.) }\end{array}$ & 40 & --- & S.E. Australia \\
\hline $\begin{array}{c}\text { Tind. } \\
\text { G. tabacina (Labill.) }\end{array}$ & 40 & $\mathrm{BB}$ & S.E. Australia \\
\hline Benth. & $\begin{array}{l}40 \\
80 \\
80\end{array}$ & $\begin{array}{l}\text { B2B2 } \\
\text { AAB2B2 } \\
\text { BBB2B2 }\end{array}$ & $\begin{array}{l}\text { N.E. \& S.E. Australia } \\
\text { South pacific Is., } \\
\text { Taiwan, S.China }\end{array}$ \\
\hline G. tomentella Hayate & $\begin{array}{l}38 \\
40 \\
78 \\
80\end{array}$ & $\begin{array}{l}\text { EE } \\
\text { DD } \\
\text { AAEE } \\
\text { AADD }\end{array}$ & $\begin{array}{l}\text { Australia, Papua New } \\
\text { Guinea, Philippines, } \\
\text { Taiwan, South China }\end{array}$ \\
\hline
\end{tabular}


Já o subgênero Soja, compreende as espécies mais importantes do gênero devido ou ao seu uso extensivo na agricultura, ou como fonte de genes, sendo que este subgênero inclui G. max ( L.) Merrill, e seu parente selvagem anual G. soja Sieb. \& Zucc. ( HYMOWITZ \& SINGH, 1987 ).

HYMOWITZ ( 1970 ) relata que vários pesquisadores efetuaram extensivos experimentos envolvendo cruzamentos entre Glycine max e Glycine ussuriensis no sentido de determinar a relação entre as duas. Estes experimentos revelaram que: ( a ) o número diplóide e haplóide de cromossomos dessas espécies e dos F1's era 40 e 20, respectivamente; ( b ) o tamanho dos cromossomos de ambas as espécies era similar; ( c ) a fertilidade dos F1's e das suas progênies era normal; e (d ) o modo de herança de caracteres tais como cor da haste, cor das flores, cor da vagem, cor da casca da semente, cor do hilo, cor da pubescência, altura de planta, tamanho de semente, formato da semente, debulha das vagens, dureza da semente, data de maturação, teor de óleo, teor de proteína e outros foram elucidados. A herança de caracteres qualitativos e quantitativos em cruzamentos entre G. max e G. ussuriensis foi similar à cruzamentos entre variedades de G. max. Os resultados citológicos acima citados permitiram à Karazawa', citado por HYMOWITZ ( 1970 ), concluir que a soja cultivada possivelmente tenha se originado da soja selvagem através do acúmulo de modificações qualitativas e quantitativas advindas de mutações gênicas, sem no entanto, apresentar alterações de ordem cromossômica.

HYMOWITZ \& SINGH ( 1987 ) também apontaram para o fato de que a soja cultivada tenha se originado de G. soja por acúmulo de mutações, pois cruzamentos entre

1KARASAWA, K. Crossing experiments with G. max and G. ussuriensis. Jap. J. Bot. 8: 1138. 1936. 
G. max e a espécie perene $G$. tomentella ( $2 n=78$ e 80 ) sugerem que os subgêneros Glycine e Soja sejam estreitamente relacionados, o que inclusive justifica o arranjo taxonômico dentro do gênero. O perenialismo das espécies do subgênero Glycine é apontado como um primitivismo em relação ao anualismo das espécies do subgênero Soja, que seria evolutivamente mais avançada neste aspecto.

Quanto à origem da soja, outro estudo foi efetuado por HAN et alii ( 1991 ) através da análise eletroforética de proteínas da semente. $O$ estudo, que objetivava elucidar as relações filogenéticas no gênero Glycine, demonstrou que havia considerável similaridade intraespecífica entre o padrão de bandas dos acessos de G. latifolia, G. microphylla, e G. max; enquanto que diferenças intraespecíficas marcantes foram encontradas em acessos de G. falcata, G. tabacina e G. tomentella. A comparação das bandas entre diferentes espécies revelou uma grande afinidade entre G. latifolia, G. microphylla, e G. tabacina. Os autores também sugerem que $G$. tomentella seja filogeneticamente relacionada à G. max.

Quanto à região de origem desta espécie, existem sugestões de que a mesma tenha se originado no leste da China ( até a antiga Manchúria), entretanto não se consegue estabelecer com certeza a época em que a domesticação aconteceu, sendo que as primeiras referências à cultura datam de aproximadamente 2800 a 2400 A.C. (PROBST \& JUDD, 1973).

Da China a soja seguiu para o Japão e Coréia, chegando à Europa em fins do século XVII, onde foi cultivada nos jardins botânicos da França como curiosidade (PROBST \& JUDD, 1973 ). Em 1804, nos Estados Unidos da América, foram feitas ocasionalmente algumas referências à soja em estações experimentais e literatura científica. A soja foi muito 
exaltada devido à sua alta produtividade, habilidade para crescer em diversos climas e solos, e devido ao seu valor como forrageira ( SMITH \& HUYSER , 1987 ).

A introdução da soja no Brasil foi atribuída aos imigrantes japoneses ( SIMTH \& HUYSER, 1987 ). BONETTI ( 1981 ) atribui a introdução à Gustavo Dutra, em 1882 na Bahia.

A partir de 1950 com a crescente demanda de óleos comestíveis, houve apoio governamental à cultura, estabelecida definitivamente no Brasil em meados da década de 1960, quando passou a ser utilizada no sistema de rotação de culturas do trigo ( MIYASAKA, 1982 ). De 1970 até meados da década de 1980 a cultura cresceu a taxas de 25 a $30 \%$ ao ano, chegando em 1989 a ocupar aproximadamente 12 milhões de hectares em área plantada, que produziram 24 milhões de toneladas de grãos, com produtividade média de $1971 \mathrm{~kg} / \mathrm{ha}$ (ANUÁRIO ESTATÍSTICO DO BRASIL, 1991 ).

As projeções para 1993/94 davam conta de nova expansão desta oleaginosa, em percentual superior ao de suas concorrentes pela área de cultivo. Técnicos da Companhia Nacional de Abastecimento - CONAB - consideraram possivel uma ampliação de até $12 \%$ na área semeada, que poderia atingir 11,9 milhões de hectares em todo 0 País. A Associação Brasileira de Produtores de Sementes - ABRASEM - respalda esta possibilidade com seu cálculo de maior oferta de sementes fiscalizadas, $17 \%$ acima da verificada no ano passado, correspondente à atual cifra de 977 mil toneladas. Como tem ocorrido menor utilização deste tipo de semente ( estimada em $68 \%$ do total empregado ), ainda se pode esperar por algum excedente, a partir daquela disponibilidade. $\dot{E}$ importante ressaltar que, segundo a CONAB , os agricultores têm demonstrado preferência por sementes de variedades mais resistentes à pragas e doenças. (ALMEIDA, 1993 ). 


\section{2 - Produção Mundial de Soja ( óleo e farelo ) e sua Importância Econômica}

Atualmente existem 8 culturas oleaginosas básicas no mercado mundial: soja, algodão ( Gossypium spp. ( L. ), semente ), amendoin ( Arachis hypogaea L. ), girassol ( Helianthus annuus L. ), colza ( Brassica napus L. ), linhaça ( Linum utitatissimum L.), copra ( Cocus nucifera L., ou seja, côco ) e dendê ( Elaeis guineensis L. ). A participação da soja na produção mundial de óleo aumentou de $32 \%$ em 1965 para $50 \%$ em 1980 ( SMITH \& HUYSER, 1987 ).

Os quatro maiores produtores são: E.U.A., Brasil, Argentina e China, que juntos representam de 90 a $95 \%$ da produção mundial. Antes de 1970 os E.U.A. e a China eram os únicos e grandes produtores. Segundo ALMEIDA ( 1993 ) o Brasil ocupa o segundo lugar na produção mundial de soja, seguido pela Argentina, sendo que participam com 20 e $10 \%$ do total, respectivamente ( Tabela 2 ). Em 1965 o Brasil detinha somente 1,8 \% da produção mundial ( SMITH \& HUYSER, 1987 ). Para a safra 94/95 BRUGNAGO NETO ( 1994 ) aponta uma produção mundial de 132,93 milhões de toneladas, sendo que os Estados Unidos da América contribuiriam com 68,67 milhões, segundo as previsões. A safra brasileira foi reestimada para 24,0 milhões de toneladas e a da Argentina continua prevista em 12,4 milhões de toneladas.

A demanda de soja deve-se principalmente ao óleo e farelo, e somente em menor grau à uma demanda de grãos na sua forma integra ( SMITH \& HUYSER, 1987 ). Os Estados Unidos da América, a Comunidade Econômica Européia ( C.E.E. ) e o Brasil são os maiores produtores do farelo de soja, enquanto os maiores consumidores são os E.U.A., C.E.E., Leste Europeu, Japão e China. O Brasil produz farelo principalmente para exportação, 
sendo que atualmente tem a mesma fatia do mercado de exportação de farelo que os E.U.A. O farelo de soja é o principal componente de rações para animais ( SMITH \& HUYSER, 1987 ).

Tabela 2 - Produção mundial de soja nas safras 1992/93 e 1993/94 (em milhöes de toneladas).

Produtor

Produção

$1992 / 93$

EUA

Brasil

59,78

51,96

Argentina

22,30

22,60

11,00

12,00

China

10,30

11,60

India

3,70

4,20

Paraguai

Canadá

Indonésia

1,80

1,39

1,80

1,58

1,85

CEI

0,66

1,63

CEE

Europa Oriental

1,16

0,80

0,32

Outros

3,36

0,72

0,28

Mundo

113,00

3,48

116,76

Fonte: USDA, Setembro de 1993. ( ALMEIDA, 1993)

O óleo de soja responde por 20 a $25 \%$ do total de óleos produzidos no mundo e 30 a $35 \%$ do total da produção de óleos comestíveis. Os outros óleos têm uma produção muito menor, porém convém lembrar os enormes e recentes aumentos na produção de óleo de dendê, cuja previsão é que venha a tornar-se um sério competidor do óleo de soja. 
Os E.U.A., C.E.E. e Brasil produzem a maioria do óleo de soja, respondendo respectivamente por 43,16 e $13 \%$ do total do óleo de soja produzido mundialmente ( SMITH \& HUYSER, 1987 ).

Historicamente o farelo de soja responde por 60 a $70 \%$ do valor da soja, sendo o restante devido ao óleo. O óleo de soja tem muitos substitutos porém o farelo de soja domina com exclusividade o mercado de proteína para alimentação animal. Isso implica em que, a soja é relativamente mais dependente do mercado de farelo do que do mercado de óleos ( SMITH \& HUYSER, 1987 ).

Quanto às tendências da produção mundial, estudos indicam uma projeção de $4 \%$ de incremento anual na produção e demanda de soja nos próximos 20 anos. Os mesmos estudos estimam um crescimento no consumo de farelo em $4,6 \%$ ao ano durante os próximos 20 anos, o que é bem menor do que o crescimento anual dos últimos 20 anos, que foi de 7,5 \% ( SMITH \& HUYSER , 1987 ).

De acordo com HURBURGH et alii ( 1990 ) os teores de proteína e óleo da soja determinam a quantidade e qualidade dos produtos finais ( farelo e óleo de soja ) que poderão ser produzidos a partir de um bushel ( unidade de volume equivalente à 35,238 litros nos E.U.A. ) de soja. Assim, quanto à importância econômica, variações geográficas destes caracteres serão importantes para compradores e vendedores caso haja diferenciação no preço baseado nos teores de proteína e de óleo.

A associação japonesa de processadores de óleos de sementes provê anualmente dados mostrando o conteúdo médio de proteina e óleo das sojas importadas dos E.U.A. [ $n^{\circ} 2$ amarela, e Indiana Ohio Michigan ( I.O.M. ) ], Brasil, Argentina e China. 
Durante os anos de 1972 a 1988 a soja $n^{\circ} 2$ dos Estados Unidos continha cerca de 1 a $1,5 \%$ a menos de óleo do que a soja brasileira. Recentemente a soja brasileira vem também apresentando um teor proteico superior a soja norte americana, inclusive superando o teor proteico da soja I.O.M. ( soja alimento de maior tamanho, que tem menos de 2.000 sementes/bushel ; bushel = 35,238 litros E.U.A. ). Assim, a participação da soja dos E.U.A. nas importações japonesas caiu de 95 \% em 1984 para 75 \% em 1988 ( HURBURGH et alii, 1990 ).

Visto que a soja brasileira tem consistentes e crescentes vantagens econômicas sobre a soja dos Estados Unidos, no que se refere à proteína e óleo, HURBURGH et alii ( 1990 ) sugerem que os Estados Unidos usem suas vantagens logísticas, crediticias e de disponibilidade, a fim de compensarem a flagrante desvantagem da qualidade de sua soja, em relação à brasileira.

\section{3 - Variações no Teor de Óleo e Proteína}

Sabe-se que os teores de óleo e proteína são determinados geneticamente porém com certa influência ambiental.

GUODONG \& JINLING ( 1989 ) verificaram a variação nos teores de óleo e proteína em soja de acordo com o período ( década) e de acordo com a geografia. Verificaram que as variedades lançadas na década de 50 eram as mais ricas em proteína, comparadas com as da década de 60,70 e 80 . O teor de proteína varia também conforme 0 local de plantio, havendo variações de 1,48 \% para proteina, e 0,81\% para teor de óleo. 
LAM-SÁNCHEZ et alii ( 1989 ) estudaram o retardamento da colheita em 36 linhagens de soja, e o efeito deste fator sobre os teores de proteina e óleo. Verificou-se em ambos os caracteres um efeito significativo de genótipos e do retardamento da colheita ( estágio $R_{8}+7$ dias; $R_{8}+14$ dias ), entretanto para teor de óleo também houve significância para a interação destas duas fontes de variação, o que não ocorreu para teor de proteína. 0 teor de óleo comportou-se do seguinte modo: $R 8=18,10 \%$; $R 8+7$ dias $=18,64 \% ; R 8+14$ dias $=19,72 \%$. O teor de proteína comportou-se de modo semelhante: $R 8=40,59 \% ; R 8+7$ dias $=40,89 \% ; R 8+14$ dias $=41,38 \%$.

Dados dos Estados Unidos da América de 1986 a 1988 mostraram diferenças consistentes entre estados e regiões quanto ao teor proteico e teor de óleo. Grãos de soja provenientes dos estados do norte e oeste ( North Dakota, South Dakota, Minnesota, lowa, Wisconsin ), região mais fria e com verão mais ameno, contém 1,5 a 2 \% menos proteina que as sojas do sudoeste ( Texas, Arkansas, Louisiana, Mississipi, Tenessee, Kentuchy, Alabama, Georgia, South Carolina, North Carolina ), região mais quente. Diferenças estaduais e regionais na composição representam US\$ 0,014 ( centavos de dólar) por litro ( unidade de volume ) no Valor de Processamento Estimado ( Estimated Processed Value ) dos preços do farelo e óleo de soja. Os desvios padrão encontrados na composição da soja de 1986 a 1988 , considerando-se uma umidade de $13 \%$, foram: $1,5 \%$ para proteina dentro de ano; $0,75 \%$ para óleo dentro de ano; $1,35 \%$ para proteína dentro de região; $0,70 \%$ para óleo dentro de região; $1,15 \%$ para proteína dentro de estado; $0,60 \%$ para óleo dentro de estado. A variação na altitude do local de plantio pode atingir aproximadamente $4 \%$ (isto é, dois desvios padrão ) para teor de proteina e $2 \%$ para óleo, sugerindo ser a altitude um fator muito importante. Quanto à latitude, os dados de uma empresa que efetua plantios do norte ao sul dos Estados Unidos da América demonstraram que existia uma correlação de $-0,77$ entre o teor proteico e a latitude norte ( HURBURGH et alii, 1990 ). 
WATANABE \& NAGASAWA (1990) analisaram, através de espectroscopia infravermelha, uma coleção de germoplasma do Japão ( com 4.400 entradas, das quais $18 \%$ coletadas no Japão ). Nesta coleção, oriunda principalmente da Ásia, a percentagem de proteina aumentou e os lipidios decresceram à medida que a latitude do sítio de coleta e o tamanho da semente diminuiam.

KILEN ( 1990 ), trabalhando com a cultivar Tracy - M e com 3 isolinhas que diferiam da original devido aos genes sb ( brachytic stem = braquiticas ), In ( narrow leaflet $=$ folíolos próximos ) e sbln ( combinação dos dois ) observou que o teor médio de proteína foi alto e o de óleo baixo para os grupos braquítico ( sb ) e braquítico de folhas próximas ( sbln ), porém no grupo com folhas próximas ( In ) o teor de proteína era menor e não havia significativa diferença para o teor de óleo quando comparado com Tracy-M. O autor sugere que essa aparente associação entre caule braquítico e teor de proteina deveria ser melhor estudada usando-se outras cultivares.

JUNZHENG \& ZHIHONG ( 1991 ) estudaram 148 variedades de soja que foram desenvolvidas na província de Heilongjiang ( China ) desde 1949. Para o estudo, as variedades foram divididas em 3 grupos de maturação. Uma análise química da composição de 12 variedades lançadas nos anos 50 revelou um conteúdo médio de proteina de $43,3 \%$, conteúdo de óleo de 19,5\%; carboidratos $32,4 \%$, e cinzas $4,9 \%$. Nos últimos 40 anos verificou-se que o conteúdo de proteina caiu, o de óleo subiu pouco, juntamente com o conteúdo de carboidratos, e houve certo acréscimo no teor de cinza. Houve acréscimo no teor de óleo visto que este caráter é correlacionado positivamente com produção de grãos.

O teor de proteína diminuiu linearmente dos anos 50 aos 70 , e o conteúdo nos anos 80 era $1,4 \%$ menor do que nos anos 50 . A mudança no teor de proteina variou 
conforme o grupo de maturação, sendo que diminuiu $3,2 \%$ para 0 grupo I ( $<105$ dias ), e $1,1 \%$ para o grupo III ( $>121$ dias ). $O$ teor de proteína nas variedades lançadas nos anos 70 era $2 \%$ menor do que nos anos 50 . Houve depois certo acréscimo nos anos 80 . A variação no teor proteico entre diferentes regiões foi de $2 \%$, o que superou a maior diferença nas distintas regiões em 2 anos ( $1,2 \%)$. O efeito compreendido entre as condições climáticas e as condições geográficas foi mais forte do que o fator climático isolado. Os dados indicam que o melhoramento do teor de proteína através do uso de médias somente, não é muito fácil, se pretendemos aumentar o conteúdo de proteina de uma cultivar em particular. A variação no teor de óleo entre regiões foi de $1 \%$, e entre décadas foi de $0,5 \%$. A diferença entre 2 anos, na região com maior diferença entre anos, foi de $1 \%$; logo 0 efeito do clima e 0 efeito geográfico são parecidos para teor de óleo. A variação nas décadas foi pequena, o que segundo os autores, indica que o melhoramento é dificil e demorado.

ISHIGE ( 1984 ) verificou que a variância do conteúdo de proteina entre sementes de uma mesma planta variou de 1,81 a 5,64 , com uma média de 3,70 em sementes $F 1$, enquanto que a variância em sementes $F 2$ não foi maior do que as linhas parentais e as sementes F1. Assim, o autor concluiu que a seleção baseada no conteúdo proteico de uma única semente em F1 não é eficiente. Concomitantemente examinou também o teor de proteína das sementes de 20 plantas em cada uma das 22 variedades. A variação no teor proteico entre plantas dentro de uma variedade variou de $0,86 \%$ a $2,66 \%$. A variação no teor de proteina nas 22 variedades foi de $33,5 \%$ a $45 \%$.

WILCOX ( 1986 ) cita que alguns acessos da coleção de germoplasma dos Estados Unidos da América têm um teor proteico de $52 \%$, mas são agronomicamente pobres e propriciam baixas produções de grãos. Já CHMELEVA \& KORSAKOV ( 1981 ) caracterizaram uma coleção de soja quanto ao teor de proteina e qualidade das sementes na 
Rússia. Uma variação no teor proteico de $28,5 \%$ a $56 \%$ foi encontrada nos 2000 acessos estudados, 90 dos quais detinham elevado teor de proteina ( $\geq 50 \%$ ).

Além disso, variações nos constituintes químicos das sementes de soja podem ser induzidas, por exemplo, através de mutações, podendo esta metodologia eventualmente ser útil no melhoramento. É o caso de PROKUDIN ( 1987 ), que realizou um estudo da composição química das sementes de soja mutantes, e não mutantes ( acessos originais ). Dos 127 mutantes produzidos pela Universidade de Voronezh (URSS) através de mutagênicos químicos e físicos aplicados sobre quatro variedades de soja, verificou-se que a variação do conteúdo proteico das sementes dependia do genótipo da planta original, sendo que a variação foi de $29,9 \%$ a $50 \%$, nas plantas mutantes, enquanto essa variação foi da ordem de $40,8 \%$ a $43,4 \%$ nas variedades originais. O conteúdo de proteína era de $42,1 \%$ a $44 \%$ na maioria dos mutantes, mas um certo número deles apresentava teor de proteína superior à $48 \%$. Também é digno de nota o fato de terem aparecido, entre os mutantes, 31 genótipos ricos em óleo, 5 mutantes combinando alto teor proteico e óleo, e 18 mutantes combinando alto teor proteico e elevada produção de grãos.

KIM et alii ( 1993 ) examinaram os componentes das sementes de 1081 genótipos de soja ( 972 de cor preta e 109 de outras cores ) e verificaram que o teor proteico variava de $34,1 \%$ a $48 \%$, enquanto os lipídios variavam de $14,1 \%$ a $23,8 \%$.

De acordo com revisão feita por ESCALANTE \& WILCOX ( 1993a ), as cultivares de soja nos E.U.A. variam de $39 \%$ a $42 \%$ de proteína na semente, embora existam acessos com mais de $50 \%$. 
Quanto à variações dos constituintes das sementes dentro de plantas COLLINS

\& CARTTER ( 1956 ) reportaram que sementes do quarto inferior da cultivar "Lincoln" possuiam em média $1,2 \%$ a menos de proteína do que sementes do topo. KOCHEGURA (1982) também verificou que sementes oriundas de posições mais altas em dois cultivares de soja apresentavam maior teor proteico do que sementes em posições inferiores. A variação no conteúdo proteico foi de $3,8 \%$ em um cultivar e $2 \%$ no outro. TAKAGI et alii ( 1982 ) encontraram teores de $39,1 \%$ no quarto basal e $40,6 \%$ no quarto superior em plantas de soja. HUSKEY et alii ( 1990 ) avaliaram o teor proteico de 241 sementes de diferentes posiçőes na cultivar "Forrest". No terço superior verificou-se teor proteico de $41,5 \%$, e no terço inferior $41,0 \%$, sendo que esta diferença não foi significativa estatisticamente. No terço intermediário o teor foi de $39,2 \%$.

ESCALANTE \& WILCOX ( 1993a ) verificaram que o teor proteico crescia linearmente do sexto nó ( a contar de baixo ) até o décimo sétimo nó ( nó produtivo distal ) em linhagens normais e linhagens de alto teor proteico. A variação entre nós alcançou $34,4 \%$ a $43,2 \%$ para linhas de teor proteico normal e de $42 \%$ a $50,9 \%$ para genótipos de alto teor proteico. Nenhuma diferença foi detectada quanto ao teor proteico dentro de vagens em ambos os tipos de linhagens.

Sementes de soja provenientes de posições mais altas nas plantas tendem a ter um menor teor de óleo e um maior teor de proteína ( ESCALANTE \& WILCOX, 1993b). COLLINS \& CARTTER ( 1956 ) identificaram que, nas cultivares indeterminadas "Earlyana e Lincoln", as sementes dos nós basais detinham maior teor de óleo, enquanto que as sementes dos nós superiores e terminais eram $2 \%$ a $6 \%$ mais pobres em óleo. Porém estes mesmos autores estudando a cultivar determinada "Jogun", verificaram que o teor de óleo decrescia marcadamente do topo para a base, contrariando a observação anterior. Também HUSKEY et 
alii ( 1990 ), trabalhando com a cultivar determinada "Forrest", verificaram que as sementes da porção mediana da planta eram as mais ricas em óleo, e, consequentemente, as mais baixas em proteína. ESCALANTE \& WILCOX (1993b) estudaram a variação no teor proteico de sementes entre os nós de isolinhas determinadas e indeterminadas. A variação foi muito semelhante, sendo que pode-se sintetizar que ocorreu um acréscimo linear, no teor proteico, da base para o ápice tanto nos genótipos determinados como nos indeterminados.

Quanto as diferentes posições das sementes dentro das vagens, nota-se que os dados da literatura são conflitantes quanto a variação no teor proteico. Os dados de COLLINS \& CARTTER ( 1956 ) revelaram que as sementes nas posições apicais das vagens da cultivar "Lincoln" são ligeiramente inferiores no teor proteico das sementes da região basal e intermediária. Contrastando, HUSKEY et alii ( 1990 ) não encontraram diferenças significativas no teor proteico entre sementes de diferentes posições dentro das vagens da cultivar "Forrest".

\section{4 - Herança}

BRIM ( 1973 ) argumenta que o conteúdo de óleo é determinado primariamente pelo genótipo do parental maternal. Logo, seleção para percentagem de óleo entre sementes individuais na mesma planta é ineficiente.

ISHIGE ( 1984 ), concluiu através do estudo de sementes $F 1$, que existem diferenças significativas nos efeitos maternos, mas não em efeitos paternos. Isso sugere, segundo o autor, que o teor proteico em sementes de soja é determinado pelos genótipos das plantas mäes e não pelo genótipo das próprias sementes após a fertilização. Entretanto, teor proteico das sementes em plantas F1 não mostrou efeitos maternais diferentes. $O$ efeito 
genético aditivo para esse caráter em plantas F1 foi estatisticamente significativo, mas a dominância, efeitos citoplasmáticos, e efeitos de interação não foram significativos. A estimativa do número de genes ficou entre dois ou três.

CHAUHAN \& SINGH ( 1983 ), que estudaram os parentais e $15 \mathrm{~F}$ 's num dialelo com seis parentais ( sem recíprocos ), encontraram variâncias da capacidade geral e específica de combinação altamente significativas para teor proteico e teor de óleo. Consequentemente, concluem que, a ação gênica aditiva e a não aditiva estão envolvidas. A análise dos componentes genéticos indicou dominância parcial para ambos os caracteres. 0 alto teor proteico foi influenciado por genes dominantes enquanto genes recessivos e dominantes regiam o teor de óleo.

A herança do teor de proteína, teor de óleo, e a soma de ambos, foi estudada por McKENDRY et alii ( 1985 ) em dois cruzamentos entre sojas precoces, em dois anos em um só local. Concluiram os pesquisadores que, o teor de proteína era de herança primariamente aditiva, com dominância parcial para baixo teor de proteína. $O$ teor de óleo também foi condicionado primariamente por genes de ação aditiva. Dominância parcial não foi consistentemente detectada durante os anos. A soma de óleo e proteína foi condicionada somente por genes de ação aditiva. A análise de variância indicou uma predominância da variância aditiva para todos os três caracteres. A variância de dominância também foi detectada para proteína e proteína + óleo. A herdabilidade no sentido amplo para a geração $F_{2}$ variou de $76 \%$ a $83 \%$ para proteina e $68 \%$ a $86 \%$ para a soma proteína e óleo, enquanto a herdabilidade no sentido restrito variou de $34 \%$ a $72 \%$ para proteína e de $39 \%$ a $65 \%$ para a soma. Para óleo a herdabilidade nos dois sentidos se igualou, variando de $58 \%$ a $68 \%$. Os autores concluem que a seleção para a soma da porcentagem de proteína e porcentagem de óleo poderia ser um índice eficiente para melhorar o teor de ambos 
concomitantemente, uma vez que a expressão dessa soma parece ser controlada somente por genes de ação aditiva e a proporção da variação que pode ser fixada hereditariamente é moderadamente alta. Seleção para a soma proteina e óleo é importante economicamente, uma vez que um aumento num deles não necessariamente seria acompanhado por uma queda no outro, como usualmente ocorre em caracteres negativamente correlacionados, quando a seleção é limitada à cada caráter independentemente.

WANBIN \& JINLING ( 1986 ) compararam a herança de vários caracteres de interesse agronômico entre Glycine $\max x$ Glycine soja ; Glycine max $x$ G. gracilis ; e G. $\max \times$ G. max. Individuos mais prolificos em vagens, e com maior teor proteico ocorrem mais frequentemente nas progênies de G. $\max \times$ G. soja . Os autores também concluiram que os efeitos genéticos aditivos são os efeitos predominantes para teor de proteína, e são maiores nos cruzamentos $G . \max \times$ G. soja e G. $\max \times$ G. gracilis . Expectativas de ganho genético no teor de proteinas, peso de sementes, e número de sementes por planta são maiores nos cruzamentos G. $\max \times$ G. soja e G. $\max \times$ G. gracilis . Isso demonstra, segundo os autores, que tais combinações prometem muito no que tange à seleção de progênies com alto teor proteico e alta produção.

GHASSEMI et alii ( 1987 ) verificaram, através da análise dos dados de um dialelo $6 \times 6$, que a herança do teor de proteína era do tipo sobredominância, e para teor de óleo era do tipo dominância parcial. Já outros autores citam que os modelos genéticos usados nos seus estudos indicaram ausência de dominância e efeito epistático na maioria dos cruzamentos estudados para teor de proteina e em todos os cruzamentos onde o teor de óleo foi estudado ( YU \& GAI, 1991 ). Outro estudo demonstra que os caracteres teor de óleo, teor de proteína e proteína+óleo são de herança predominantemente aditiva ( SONG et alii, $1991)$. 
PULCINELLI ( 1992 ), estudando a herança do teor de proteína em soja, chegou a conclusão de que o teor de proteína das sementes em soja é determinado pelo genótipo materno, não havendo evidências do efeito do genótipo do embrião e do citoplasma. Assim sendo, a seleção dentro de plantas segregantes é inoperante. $O$ autor também concluiu que o teor de proteína em soja está sob o controle de genes com ação aditiva somente. Já a produção de grãos em soja está sob o controle de genes com ação aditiva e dominante porém, efeitos epistáticos não podem ser desconsiderados segundo o autor.

Quanto à herdabilidade, vários autores obtiveram estimativas aproximadamente concordantes. OPENSHAW \& HADLEY ( 1981 ) obtiveram estimativas de herdabilidade que variaram de $57 \%$ a $90 \%$ para proteína, e $51 \%$ a $89 \%$ para óleo. Para o caráter produção de grãos os autores encontraram herdabilidades variando de $3 \%$ a $58 \%$.

Também BAYS ( 1975 ) trabalhando com gerações F3 e F4 de dois cruzamentos obteve valores de herdabilidade para PG variando de $18 \%$ ( F4) a $55 \%$ ( F3 ) no cruzamento 1 ( Hill X Bragg); e de $24 \%$ ( F3 ) a $44 \%$ ( F4) no cruzamento 2 ( Hood X Bragg ).

MONTEVERDE ( 1984 ) estudando correlações fenotípicas e genotípicas em soja, obteve estimativas de herdabilidade para produção de grãos em três populações da ordem de $54 \%, 34 \%$, e $11 \%$; para teor proteico as estimativas foram de $56 \%$, $50 \%$ e $28 \%$; e para teor de óleo a herdabilidade média foi de $57 \%$. OPENSHAW \& HADLEY ( 1984 ) obtiveram herdabilidades de 0,90 ( $\pm 0,02)$ para proteína, e 0,93 ( $\pm 0,01)$ para teor de óleo numa das populações trabalhadas, enquanto que em outra obtiveram $0,75( \pm 0,03)$ e 0,71 ( $\pm 0,03)$, respectivamente. Também SHARMA et alii ( 1986 ), estudando 45 genótipos e 15 caracteres em sojas de grãos pequenos, obtiveram uma herdabilidade para porcentagem de 
proteína de $41,9 \% ; 43,9 \%$ para óleo, e $31,1 \%$ para produção de grãos por planta. Outro autor obteve estimativas de herdabilidade para óleo e proteína acima de $80 \%$ (CHEN, 1987).

SURLAN-MOMIROVIC ( 1987b) obteve altos coeficientes de herdabilidade para teor proteico ( $83.1 \%$ ) e para conteúdo de ácido linoleico ( $92,7 \%$ ) quando estudou 12 variedades de soja. Para o caráter produção de grãos, KAMIKOGA ( 1989 ) obteve herdabilidades, para o caráter produção de grãos, no sentido amplo, oscilando de $44 \%$ a $75 \%$ em quatro populações segregantes de soja obtidas de cruzamentos de materiais cultivados com uma introdução exótica ( parental masculino ) suscetível ao acamamento.

Portanto, teor de óleo e teor de proteína são caracteres de mais elevada herdabilidade do que produção de grãos em soja.

\subsection{Correlacões entre Caracteres}

JOHNSON et alii ( 1955 ) lembram que estimativas das correlações genotipicas e fenotipicas entre caracteres são úteis no planejamento e avaliação de programas de melhoramento. O conhecimento sobre correlaçöes que existam entre caracteres importantes pode facilitar a interpretação dos resultados já obtidos e provê maior base para o planejamento de eficientes programas no futuro. Também as correlações entre caracteres importantes e não importantes pode revelar que alguns dos últimos poderiam ser úteis como indicadores de um ou mais caracteres econômicos ( importantes ). Isso é muito útil no processo de seleção. É conhecido que a ligação gênica pode ser a causa das diferenças nas correlações entre caracteres em populações segregantes de soja, mas neste caso, o estudo demonstrou que não havia suficiente evidência para isto. A ligação entretanto, não pode ser eliminada 
como fonte de algumas correlações observadas no estudo de JOHNSON et alii ( 1955 ), mas aparentemente não é a fonte das correlações mais fortes observadas, que devem ter se originado do fato de que certos caracteres são afetados por algumas vias metabólicas comuns na planta.

Segundo BURTON ( 1987 ), no melhoramento genético é útil saber como os caracteres estão correlacionados geneticamente isto é, quando a seleção é praticada em um caráter particular, é importante saber de que maneira isso afetará outros caracteres. Isto pode ser exemplificado através do trabalho de BRIM \& BURTON ( 1979 ), que fizeram seleção recorrente para aumentar o teor de proteina em sementes de duas populações de soja, o que afetou outros caracteres. A população I era derivada de um cruzamento de duas linhagens altamente adaptadas. A população II foi gerada a partir de retrocruzamentos de nove introduções não adaptadas ( mas de alto teor proteico ) para um parental recorrente ( linhagem ) altamente adaptado. Cada população foi subdividida em uma população A e B, onde o tamanho efetivo das populações IA e IIA era aproximadamente três vezes superior ao das populações IB e IIB. O teor de proteina das sementes ( \% ) aumentou significativa e linearmente em todas as populações. $O$ teor de proteína cresceu de $46,3 \%$ a $48,4 \%$ em seis ciclos de seleção na população IA, e de 46,4 \% a 47,6 \% em quatro ciclos na população IB. Porém, na população IA observou-se um decréscimo linear no teor de óleo de 0,21 \% por ciclo, enquanto que a produção de grãos cresceu. Na população IB a resposta à seleção foi semelhante. O teor proteico cresceu em 0,29\% por ciclo, enquanto o teor de óleo decrescia $0,17 \%$ no mesmo periodo, valores estes significativamente diferentes de zero. A produção de grãos apresentou um decréscimo não significativo estatísticamente. Na população IIA o teor proteico elevou-se de $42,8 \%$ para 46,1 \% em cinco ciclos de seleção, o que em média significa 0,67 \% por ciclo. Em compensação, o teor de óleo declinou 0,42 \% por ciclo, e a produtividade 
apresentou uma queda total de $13 \%$. A população IIB apresentou comportamento muito similar à IIA.

Correlações genotípicas também são úteis para seleção simultânea de mais de um caráter, ou por indice de seleção ou seleção indireta, mas geralmente, a seleção direta é mais eficiente do que a indireta ( BURTON, 1987 ), embora esta possa ser mais eficiente quanto ao tempo requerido para completar um ciclo de seleção.

Especificamente no caso da soja, JOHNSON et alii ( 1955 ) obtiveram estimativas das correlações genotipicas e fenotípicas para as combinações entre 24 caracteres. O estudo envolveu duas populações segregantes obtidas de cruzamentos biparentais avaliadas em F4, em dois e três locais, respectivamente. Os autores encontraram correlações genéticas e fenotípicas entre percentagem de óleo e proteína da ordem de $-0,70$ e $-0,69$ para uma das populações, e de $-0,48$ e $-0,48$ para a outra. As correlações entre percentagem de proteína e produção de grãos ficaram em -0,12 e $-0,08$ para a primeira e $-0,64$ e - - 0,33 para a segunda população. Os autores obtiveram também, nas duas populações, uma correlação genética negativa da ordem de $-0,63$ e $-0,39$, entre porcentagem de proteína e resistência à debulha. Já a correlação genética entre a produção e debulha foi positiva $+0,47$ e +0,87 ). Seleção para resistência à debulha já pode ser realizada em F2 e F3, e seleção para proteína de F4 em diante. A seleção de plantas resistentes à debulha eliminaria genótipos com alto teor de proteína. É importante lembrar que as correlações entre resistência à debulha e produção ou entre susceptibilidade à debulha e proteína não foram causados pela perda de grãos devido à debulha, pois os dados de debulha foram tomados 2 semanas após a colheita, sendo que na colheita havia pouca ou nenhuma debulha. 
Em resumo, JOHNSON et alii ( 1955 ) encontraram correlações de magnitude apreciável e de valor prático entre: alta produção com longo periodo de frutificação $(+0,52)$, ciclo tardio $(+0,26 \mathrm{a}+0,75)$, sementes pesadas $(+0,45 \mathrm{a}+0,66)$, resistência à debulha $(+0,23$ a $+0,37$ ) e ao acamamento $(-0,05$ a $-0,13)$; baixa proteína com alto óleo $(-0,48$ a $-0,70)$ e resistência à debulha $(-0,34$ a $-0,63)$. A percentagem de óleo esteve mais fortemente correlacionada com florescimento precoce $(-0,24$ a $-0,27$ ), longo período de frutificação ( fase reprodutiva ) $(-0,14$ a $-0,23)$, e maturação precoce $(-0,16$ a $-0,22)$, entretanto, as correlações envolvendo teor de óleo geralmente foram de baixa magnitude.

SHANNON et alii ( 1972 ) estudaram 78 linhas F4 derivadas de F2 oriundas de seis populações provenientes de seis tipos de cruzamentos. Os autores observaram correlações genéticas altamente significativas e negativas entre proteina e óleo nas seis populações $(r=-0,46$ a $r=-0,92)$. Correlações entre produção e óleo foram positivas, mas significativas só em duas populações. Coeficientes de correlação foram significativos entre produção e percentagem de proteína em três populações, sendo estes de: $-0,28 ;-0,55 ;$ e $+0,61$.

SHORTER et alii ( 1977 ) estudaram três cruzamentos nas gerações F3 e F4 em dois locais. As correlações genotípicas entre porcentagem de proteína e produção de grãos variaram de $-0,50 \mathrm{a}+0,16$ entre cruzamentos, e foram opostas em sinal àquelas correlações entre teor de óleo e produção. Correlações fenotipicas e genotípicas entre porcentagem de proteína e óleo foram altamente negativas em dois cruzamentos $(-0,62$ a $-0,96)$ e bastante menores no terceiro $(-0,24$ a $-0,35)$. Para proteina, óleo, e proteína + óleo a variância da interação linhas $X$ locais geralmente foi menor do que a variância de linhas em dois cruzamentos. A interação linhas $X$ locais talvez seja devido a certos casos onde houve 
baixa porcentagem de proteína e porcentagem de óleo em linhas tardias nos locais onde prevaleceram condições ambientais com temperaturas mais baixas na estação de cultivo.

HOWELL \& CALDWELL ( 1978 ) relacionaram as seguintes correlações fenotípicas e genotípicas:

$$
\begin{array}{ll}
r_{G} \text { PGXTO }=+0,107 & r_{F} \text { PGXTO }=+0,069 \\
r_{G} \text { PGXTP }=-0,226 & r_{F} \text { PG } \times \text { TP }=-0,139 \\
r_{G} \text { TPXTO }=-0,560 & r_{F} \text { TPXTO }=-0,545
\end{array}
$$

Quanto à composição das sementes, OPENSHAW \& HADLEY ( 1981 ) verificaram que a correlação entre porcentagem de óleo e porcentagem de açúcar em sementes era positiva e significativa, e que a correlação entre porcentagem de proteína e porcentagem de açúcar foi significativa e negativa. Correlações entre teor de açúcares e produção foram não significativos.

RANA et alii ( 1982 ) estimaram coeficientes de correlação com base em valores médios observados a partir de 250 culturas testes ( test cultures ).

$$
\begin{array}{lr}
\text { \% proteina X produção por planta }(\mathrm{mg}) & r=-0,06 \\
\text { \% proteina X porcentagem de germinação } & r=+0,05 \\
\text { \% proteina X resistência ao esmagamento }(\mathrm{Kg}) & r=+0,13
\end{array}
$$

Tomando dados referentes à produção de sementes, porcentagem de proteína, porcentagem de óleo e outras características agronômicas em 412 progênies de soja resultantes de quatro cruzamentos entre duas linhas pouco adaptadas, mas de alto teor proteico, e duas linhagens adaptadas, de médio teor proteico, SIMPSON \& WILCOX ( 1983 ) 
obtiveram estimativas de correlações genéticas avaliadas nas gerações $F_{6}$ e $F_{7}$. A correlação genética entre produção de grãos e porcentagem de proteína variou de $-0,75$ a $+0,54$; entre produção e porcentagem de óleo de $-0,27$ a $+0,25$; entre porcentagem de proteina e porcentagem de óleo, de $-0,96$ a $-0,15$. Alto teor proteico também foi correlacionado significativamente com maturidade tardia, variando de $r=+0,19$ a $+0,44$. Em dois cruzamentos o alto teor proteico esteve correlacionado com altura de planta $(r=+0,43$ e $r=+0,33$ ), e em todos os cruzamentos o alto teor proteico correlacionou-se significativamente com sementes manchadas ( seed mottling), com $r=+0,35$ a $r=+0,27$. O número de " nós " também estava positivamente correlacionado ao teor de proteína $(r=+0,50)$, igualmente 0 número de ramos $(r=+0,57)$, o total de nós por ramo $(r=+0,52), 0$ total de vagens por ramo $(r=+0,52)$, e o número de sementes por ramo $(r=+0,48)$.

No estudo realizado por SEBERN \& LAMBERT ( 1984 ) os coeficientes de correlação para porcentagem de proteina e produção de grãos variaram de $-0,23$ a $-0,58$ e foram altamente significativos para as linhas $F_{6}$ nas duas populações avaliadas. Já as correlações entre a porcentagem de proteina e a porcentagem de óleo variaram de $-0,11$ a $-0,44$. Somente um dos coeficientes foi significativo. Os coeficientes de produção de grãos versus teor de óleo foram positivos, mas somente um deles foi significativo. Concluiram os autores que seu estudo mostrava, assim como vários outros, a dificuldade de se obter cultivares altamente produtivos e também com alto teor de proteína e óleo. $O$ estudo foi realizado com duas populações de soja , Glycine max ( L. ) Merrill, cada uma tendo no mínimo um parental com alto teor de proteina. A finalidade era determinar os efeitos da

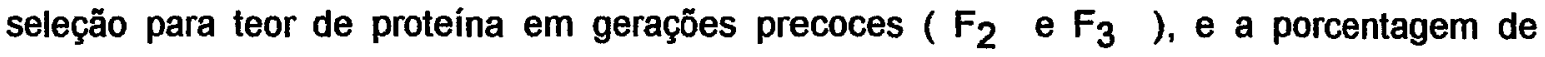
proteina nas sementes, porcentagem de óleo e produção de grãos em gerações avançadas $\left(\begin{array}{lll}F_{4} & \text { e } F_{6}\end{array}\right)$. Apesar da correlação negativa entre porcentagem de proteina e produção de 
grãos, e entre porcentagem de proteina e porcentagem de óleo foram identificadas linhas $F_{6}$ com combinações desejáveis de óleo, proteína e produção.

MONTEVERDE ( 1984 ) estudou as correlações fenotípicas e genotípicas entre produtividade, proteína, óleo e outras características em soja. Para tanto, usou as progênies obtidas em cruzamentos onde estavam envolvidos sempre um parental com alto teor de proteína e elevada produtividade com outro parental de baixo teor proteico e baixa produtividade. Foram escolhidas ao acaso 30 linhas $F_{3}$ de cada uma das três populações derivadas do cruzamento de pais altamente produtivos e com alto teor proteico ( Hutton, F66-698 e F66-216 ) com Roanoke, cujas características eram opostas. As linhas foram avaliadas na Flórida em 1976. As correlações fenotípicas entre produção de grãos e porcentagem de proteína foram de $+0,07,-0,05$ e $-0,25$ para as populações 1,2 e 3 respectivamente, o que se assemelha à dados já reportados na literatura. Entretanto, as correlações genéticas entre estes dois caracteres foram positivas e altas, apresentando valores bem maiores do que os citados na literatura, isto é: $+0,49,+0,33, e+0,58$. Isso sugere que a direção e a magnitude das correlações genéticas entre produção e proteina são influenciadas pela maneira como esses caracteres estão associados nos pais. Entretanto, MONTEVERDE ( 1984 ) chama a atenção para o fato de que no seu estudo, as variâncias e covariâncias genéticas possam estar inflacionadas, visto que contém as interações de genótipos x locais ( $G \times L)$, genótipos $\times$ anos $(G \times A)$ e genótipos $\times$ locais $\times$ anos $(G \times L \times A)$. Esses resultados, segundo o autor, enfatizam a necessidade de remover os componentes de variância associados com locais e anos em populações similares para identificar mais precisamente a natureza das correlações genéticas entre produção e proteína.

Já OPENSHAW \& HADLEY ( 1984 ), que trabalharam com duas populações oriundas de dois cruzamentos, acreditam que as interações genótipos $X$ ambientes não sejam 
importantes. As herdabilidades, correlações genotípicas e fenotipicas foram calculadas com base nas análises de variância e covariância da geração $F_{3}$. Os autores obtiveram numa das populações, uma correlação fenotípica entre teor de proteina e teor de óleo de $-0,80$. A correlação genotípica entre estes dois caracteres para essa população $\left(n^{\circ} 1\right)$ foi de $-0,83$, enquanto que para outra população $\left(n^{\circ} 2\right)$ foi da ordem de $-0,68$. Visto que os ensaios foram feitos em um só ambiente, essas estimativas podem estar inflacionadas pelas interações genótipo $X$ ambiente, que geralmente não são importantes para esses caracteres, segundo os autores.

MAYOR \& BAYÓN ( 1985 ) estudaram três variedades de soja, e obtiveram uma correlação positiva e altamente significativa para o caráter "dias até a floração" e porcentagem de proteína $(+0,71)$, " dias até a maturação " e porcentagem de proteína ( $+0,88$ ); e período de frutificação e porcentagem de proteínas ( $+0,48)$; e nenhuma significância para porcentagem de proteinas e tamanho da semente $(+0,29)$.

MAYOR \& SOTO ( 1985 ) calcularam todas as correlaçōes possiveis entre nove caracteres em seis cultivares de soja em duas épocas de semeadura em Cuba. Obtiveram uma correlação de $+0,10$ entre teor de proteina e teor de óleo no verão, e $+0,43$ no inverno. Entre porcentagem de proteína e produtividade de grãos obtiveram correlação de $+0,12$ no verão e $+0,02$ no inverno; já entre porcentagem de óleo e rendimento a correlação foi de $+0,12$ no verão e $+0,49$ no inverno. Os autores concluíram que a correlação positiva e significativa a $1 \%$ entre teor de óleo e proteina no inverno demonstra que existe a possibilidade, nas condições citadas, de encontrarem-se linhas que reúnam bom conteúdo de óleo e proteina. Em outro estudo, desenvolvido por MAYOR \& SOTO ( 1986 ) com variedades de soja, encontrou-se uma correlação entre porcentagem de óleo e proteina de $+0,14$. 
SHARMA et alii ( 1986 ) estudaram a variabilidade genética de 15 caracteres em 45 genótipos de soja de grãos pequenos coletados em diferentes partes da Índia, e obtiveram uma correlação entre óleo e proteína de -0,271.

SURLAN-MOMIROVIC ( 1987b) estudando 12 variedades de soja quanto à produção de grãos, teor proteico , teor de óleo e conteúdo de ácidos graxos, encontrou uma significativa correlação negativa entre produção de grãos e teor de proteína $(r=-0,52)$. Correlações negativas também foram observadas entre produção e teor de óleo $(r=-0,50)$, e entre óleo e proteína $(r=-0,32)$.

Em outro trabalho de SURLAN-MOMIROVIC ( 1987a ), também desenvolvido com 12 variedades de soja, verificou-se que as correlações genotípicas entre produção de grãos e caracteres morforlógicos foram maiores do que as correlações fenotípicas, indicando que o ambiente desempenhou um papel significativo nesses casos, enquanto que em algumas correlações entre produção de grãos e os constituintes químicos, a influência do ambiente foi mínima. Correlações negativas significativas ocorreram entre produção de grãos e teor de proteina $(r=-0,516)$.

BURTON ( 1987 ) apresenta diversas correlações entre produção de grãos e outros caracteres, oriundas de diversos trabalhos de outros autores. As correlações genéticas entre produção e proteína variaram de $-0,74$ a $+0,35$, e as correlações entre produção e teor de óleo variaram de $+0,45$ a $-0,27$. O autor menciona que torna-se evidente, através das diferenças entre os coeficientes de correlação de quaisquer dois caracteres, que a significância assim como a direção das correlações depende da população nos quais os caracteres são mensurados. 
MAYOR et alii ( 1988 ) estudaram as correlações em 13 variedades de soja em duas estações em dois anos, e em geral, as correlações genéticas foram superiores as fenotípicas, sendo que a correlação ambiental foi alta somente entre produção de sementes e produção de proteína. $O$ melhor caráter a ser considerado num índice de seleção para produção de proteína foi a fase de floração-maturação ( $r_{G}=-0,759$ ), juntamente com a seleção para florescimento tardio. Outras correlações genéticas observadas foram ( no verão):

$\begin{array}{lc}\text { Peso de } 100 \text { sementes X\% Proteína } & r=+0,663 \\ \text { Dias até maturação técnica X\% Proteína } & r=-0,513 \\ \text { Dias até maturação técnica X produção de proteína } / m^{2} & r=+0,959\end{array}$

VASHCHENKO et alii ( 1989 ) estudaram 380 genótipos de soja de diferentes origens geográficas, pertencentes a cinco grupos de maturidade na área de Primorie ( maritima ) do leste soviético. Verificou-se que existia uma correlação negativa entre proteína e teor de óleo, que variou de $-0,26$ no grupo semi-precoce ( 171 genótipos ) a -0,72 no grupo tardio ( 17 genótipos ). O coeficiente de correlação diminuia à medida que o número de acessos, por grupo de maturação, crescia. Esses resultados foram confirmados usando-se dados de testes feitos no período 1977 - 1986 , estudando-se 44 a 61 acessos por ano. Os coeficientes de correlação não foram mais altos do que $-0,40$ nos 520 acessos estudados.

Apesar de toda a literatura citada até o momento mostrar que usualmente a produção de grãos está negativamente associada com teor proteico, algumas vezes encontramos casos onde esta barreira foi transposta, obtendo-se com sucesso genótipos interessantes sob o aspecto de ambos os caracteres, como no caso de WEHRMANN et alii ( 1987 ), que conseguiram transferir a característica de alto teor de proteína para uma cultivar de elevada produção de grãos e baixo teor proteico. O estudo foi feito com " Pando ", uma introdução de soja caracterizada pela sua baixa produção de grãos e elevado teor proteico 
( $48 \%$ ). Esta foi cruzada com três linhagens de alta produção de grãos e com conteúdo médio de proteina de $40 \%$. A seleção para teor de proteína foi feita através de duas gerações de retrocruzamento para o parental de alta produção de grãos. Após dois retrocruzamentos, 95 linhas derivadas $\mathrm{BC}_{2} \mathrm{~F}_{2}$ de cada uma das populações foi avaliada. Nenhuma das linhas $\mathrm{BC}_{2} \mathrm{~F}_{2}$ igualou Pando no conteúdo de proteina, mas uma média de $72 \%$ das linhas das três populações tinha significativamente maior teor de proteina do que o pai recorrente.

No entanto, com WENBIN \& JINLING ( 1988 ) ocorreu o que normalmente é citado pela literatura. Eles estudaram através de um dialelo, a possibilidade de combinar o alto teor proteico das sojas selvagens ou semi-selvagens, com o grande tamanho de grãos das variedades cultivadas. Os resultados mostraram que à medida que houve aumento do peso de 100 sementes na população selecionada, houve também aumento do conteúdo de óleo e da produção de sementes por planta, enquanto que o teor de proteína era reduzido concomitantemente.

Quanto à associação dos caracteres, como vimos até o momento, o teor de proteína tem sido correlacionado negativamente com o teor de óleo. Entretanto, HUANG \& TONG (1990), analisando 352 acessos de soja selvagem [ Glycine soja ] e 16 acessos de soja semi-selvagem coletadas em Fujian ( 1986 ), verificaram que o teor de proteína era positivamente correlacionado com teor de óleo em ambos os tipos, selvagem $(r=+0,14)$ e semi-selvagem $(r=+0,62$ ). Concluiram que a seleção para altos teores de proteína e óleo seria mais fácil de ser obtida em genótipos semi-selvagens do que em selvagens.

Também HARTWIG \& KILEN ( 1991 ) reconheciam que a produção de grãos geralmente está associada negativamente com teor proteico da semente. Assim, realizaram um estudo com a finalidade de determinar se esta associação poderia ser minimizada através 
de cruzamento entre uma linhagem com alto teor proteico e uma com teor normal, ambas com idêntica produção de grãos. Os resultados demonstraram que havia potencial para se desenvolver linhagens de alto teor proteico atingindo patamares de produtividade tão altos quanto os cultivares de alto teor de óleo.

Também BHATNAGAR et alii ( 1992 ) irradiaram sementes das cultivares de soja PK 472 , Bragg e Gaurav com 15, 20 ou 25 kR raios gama com e sem uma exposição adicional de radiação ultravioleta ( 2 horas à $260 \mathrm{~nm}$ ). Após terem sido descartados os mutantes agronomicamente indesejáveis verificou-se que os mutantes apresentavam uma correlação negativa não significativa entre teor de óleo e teor de proteína, ou positiva e significativa, ao contrário dos progenitores, cujos valores de correlação eram negativos e significativos.

Ainda como referenciais para esta revisão a respeito da relação óleo-proteína, verifica-se que MOHAMED \& RANGAPPA ( 1992 ) encontraram significativa correlação entre estes dois constituintes em sementes de soja da ordem de $-0,52$ a $-0,62$.

XU \& WILCOX (1992) observaram coeficientes de correlação entre teor de proteina e produção de grãos variando de $+0,18$ a $-0,21$ em quatro ciclos de seleção recorrente, indicando que plantas com combinações favoráveis de produção e teor de proteína poderiam ser identificadas. A correlação entre produção e teor de óleo variou de $-0,26$ a $+0,27$, e entre teor de proteína e óleo variou de $-0,88$ a $-0,61$. Segundo os autores, a seleção recorrente, usada para aumentar a produção, tem sido menos eficiente do que para aumentar o teor proteico em soja. A seleção aumentou o teor médio de proteína significativamente em $+0,8 \pm 0,15 \%$ por ciclo e decresceu o percentual de óleo da semente ( não significativo ) em $+0,5 \pm 0,17 \%$ por ciclo. Segundo XU \& WILCOX (1992), verifica-se que os coeficientes de 
correlação entre proteína e maturidade foram significativos nos ciclos 0,1 e 4 , ( respectivamente $+0,30 ;+0,29$ e $+0,26$ ) indicando uma tendência de que plantas com alto teor de proteína alcancem a maturidade mais tarde do que as que têm teor proteico menor na semente. Já a correlação entre teor de óleo e maturidade foi geralmente negativa ou praticamente nula $(r=-0,36$ a 0,01$)$. A forte correlação negativa $(r=-0,61$ a $-0,88$ ) entre proteína e óleo foi consistente com numerosos trabalhos prévios registrados na literatura. Essa relação inversa refletiu-se também na relação do teor de óleo com maturidade e produção, comparado com a relação do teor de proteína com estes mesmos dois caracteres.

Obviamente os três caracteres, ora objetos de revisão, também estão correlacionados com diversos caracteres morfológicos, como já citado em parágrafos anteriores, sendo que REDDY et alii ( 1989 ), avaliando cinco variedades de soja quanto à classificação em três tamanhos, notaram que o tamanho da semente não teve qualquer influência sobre os caracteres estudados, exceto sobre proteina e óleo. O tamanho da semente esteve negativamente associado à teor de proteína e positivamente com o teor de óleo das sementes.

Portanto, como conclusão geral desta revisão, sumarizada através do Apêndice 4, nota-se que normalmente o teor de proteína está correlacionado negativamente com o teor de óleo e produção de grãos, podendo haver proveitosas exceções. O teor de óleo em geral é positivamente correlacionado com produção de grãos. 
Apêndice 04 - Correlações encontradas na literatura entre produção de grãos, teor de óleo e teor de proteína em soja.

\begin{tabular}{|c|c|c|c|}
\hline FONTE & $r_{\text {TO.PG }}$ & r TO.TP & r TP.PG \\
\hline \multirow[t]{2}{*}{ JOHNSON et alii ( 1955 ) } & & $r G=-0,70 \quad r F=-0,69$ & $r G=-0,12 \quad r F=-0,08$ \\
\hline & & $\mathrm{rG}=-0,48 \quad \mathrm{rF}=-0,48$ & $r G=-0,64 \quad r F=-0,33$ \\
\hline SHANNON et alii ( 1972 ) & & $r G=-0,46 a-0,92$ & $\mathrm{rF}=-0,55 \mathrm{a}+0,61$ \\
\hline \multirow[t]{2}{*}{ SHORTER et alii ( 1977) } & & $r F=-0,62 a-0,96$ & $r F=-0,50 a+0,16$ \\
\hline & & $r F=-0,24 a-0,35$ & \\
\hline \multirow[t]{2}{*}{ HOWELL \& CALDWELL ( 1976 ) } & $r G=+0,107$ & $r G=-0,560$ & $r G=-0,226$ \\
\hline & $\mathrm{rF}=+0,069$ & $r F=-0,545$ & $\mathrm{rF}=-0,139$ \\
\hline SIMPSON \& WILCOX ( 1983 ) & $r G=-0,27 a+0,25$ & $r G=-0,96 a-0,15$ & $r G=-0,75 a+0,54$ \\
\hline SEBERN \& LAMBERT ( 1984) & & $r=-0,11$ a $-0,44$ & $r=-0,23 a-0,58$ \\
\hline \multirow[t]{2}{*}{ MONTEVERDE ( 1984) } & & & $\mathrm{rF}=+0,07 ;-0,05 \mathrm{e}-0,25$ \\
\hline & & & $r G=+0,49 ;+0,33 e+0,58$ \\
\hline \multirow[t]{2}{*}{ OPENSHAW \& HADLEY ( 1984) } & & $r F=-0,80$ a $-0,68$ & \\
\hline & & $\mathrm{rG}=-0,83$ & \\
\hline \multirow[t]{2}{*}{ MAYOR \& SOTO ( 1985 ) } & $\mathrm{rF}=+0,12($ verăo $)$ & $\mathrm{rF}=+0,10($ verăo $)$ & $\mathrm{rF}=+0,12($ verăo $)$ \\
\hline & $\mathrm{rF}=+0,49($ inverno $)$ & $\mathrm{rF}=+0,43($ inverno $)$ & $\mathrm{rF}=+0,02($ inverno $)$ \\
\hline MAYOR \& SOTO (1986) & & $r F=+0,14$ & \\
\hline SHARMA et alii ( 1986 ) & & $\mathrm{rF}=-0,271$ & \\
\hline SURLAN-MOMIROVIC ( 1987b) & $r F=-0,50$ & $r F=-0,32$ & $\mathrm{rF}=-0,52$ \\
\hline SURLAN-MOMIROVIC ( 1987a) & & & $\mathrm{rF}=-0,516$ \\
\hline BURTON ( 1987 ) & $r G=+0,45 a-0,27$ & & $r G=-0,74 a+0,35$ \\
\hline VASCHENKO et alii ( 1989 ) & & $r G=-0,26 a-0,72$ & \\
\hline \multirow[t]{2}{*}{ HUANG \& TONG ( 1990$)$} & & $\mathrm{rF}=+0,14$ selvagem & \\
\hline & & $\mathrm{rF}=+0,62$ semi-selvagem & \\
\hline MOHAMED \& RANGAPPA ( 1992 ) & & $r F=-0,52 a-0,62$ & \\
\hline XU \& WILCOX ( 1992 ) & $r F=-0,26 a+0,27$ & $\mathrm{rF}=-0,88 \mathrm{a}-0,61$ & $\mathrm{rF}=+0,18 \mathrm{a}-0,21$ \\
\hline
\end{tabular}




\section{MATERIAL E MÉTODOS :}

\section{1 - Experimentação:}

Os experimentos foram realizados no município de Piracicaba localizado no interior do estado de São Paulo, a $22^{\circ} 42^{\prime}$ de latitude sul; $47^{\circ} 38^{\prime}$ de longitude oeste, e a 540 metros acima do nível do mar ( altitude média ).

No ano agrícola 1984/85 foram avaliados 141 genótipos de soja quanto à produção de grãos e porcentagem de óleo, entre outros caracteres. Entre estes genótipos estavam incluidos cultivares e linhagens experimentais correspondentes à três grupos de maturação (GM): precoce ( GMP), intermediário ( $G M I$ ), e tardio ( GMT ). Estes três grupos continham respectivamente 68, 51 e 22 genótipos da coleção de germoplasma do Setor de Genética aplicada às Espécies Autógamas do Instituto de Genética da Escola Superior de Agricultura " Luiz de Queiroz ", da Universidade de São Paulo ( USP ), município de Piracicaba ( SP ) ( SOLDINI, 1993 ).

A avaliação dos genótipos foi feita em nove experimentos distribuidos em três locais: ANHEMBI ( $L_{A}$ ) [ ambiente 1] caracterizado por solo arenoso de baixa fertilidade, semelhante aos solos encontrados nos cerrados; o uso de calcário neutralizou parcialmente a acidez do solo em anos anteriores; SERTÃOZINHO ( $L_{S}$ ) [ ambiente 2 ], com solo tipo Latossol Vermelho-Amarelo, de fertilidade intermediária, e ESALQ ( $L_{E}$ ) [ ambiente 3 ], com 
solo tipo terra roxa estruturada de alta fertilidade. Os três locais situam-se no Estado de São Paulo, município de Piracicaba.

O local $L_{A}$ está situado na Estação Experimental de Anhembi, pertencente ao Departamento de Genética/ESALQ/USP, distante aproximadamente $60 \mathrm{~km}$ de $\mathrm{L}_{E}$. $O$ local $\mathrm{L}_{S}$ situa-se numa área da empresa Caterpillar Brasil S.A., distante cerca de 5 km de LE. Em cada local foram avaliados os grupos de maturação, usando-se o delineamento de blocos ao acaso com tratamentos estratificados em conjuntos experimentais. Três testemunhas comuns participaram de todos os conjuntos do mesmo GM. Em cada local foram utilizadas duas repetições. A avaliação completa destes genótipos com ênfase em teor de óleo e produção de grãos está relatada na dissertação de mestrado de SOLDINI ( 1993 ).

Outro ensaio foi realizado no ano agrícola 1986/87, envolvendo 89 genótipos ( cultivares e linhagens ), também pertencentes a três GM diferentes. Este experimento foi delineado em blocos ao acaso com tratamentos estratificados em conjuntos, com duas repetições no local $L_{E}[$ ambiente 4 ], envolvendo também testemunhas comuns aos demais experimentos. Estes genótipos foram avaliados quanto à produção de grãos e teor de proteína, além de outros caracteres de importância agronômica.

As parcelas experimentais de todos os ensaios foram representadas por quatro fileiras de 5,0 metros de comprimento, espaçadas de 0,60 metros, constituindo uma área útil de colheita de 4,8 metros quadrados em todos os ensaios ( $84 / 85$ e $86 / 87$ ).

Dos genótipos avaliados nos experimentos, 30 eram comuns a todos, sendo portanto, considerados para os estudos de correlação entre alguns caracteres neste trabalho, 
a saber: teor de óleo ( experimentos de 1984/85 ), teor de proteína (experimento de 1986/87) e produção de grãos (experimentos de 1984/85 e 1986/87 ).

Dentre os caracteres envolvidos, a produção de grãos ( PG ) compreendeu o peso das sementes ( gramas ) de todas as plantas localizadas na área útil de cada parcela ( 4,8 metros quadrados ). Já o teor de óleo ( $\%$; TO ), avaliado somente no ano $1984 / 85$, foi determinado a partir de uma amostra de 20 sementes ( com $6 \%$ de umidade ) no espectômetro de ressonância nuclear magnética ( NMR ), no laboratório de Física da UNICAMP ( convênio FINEP/UNICAMP/USP/IAC ).

O Teor de proteína ( $\%$; TP ) foi determinado com base em amostras de sementes no setor de Genética Fisiológica do Departamento de Genética da ESALQ/USP pelo método de Kjeldhal ( $N \times 6,25)$.

\section{2 - Análises da Variância e Estimativas de Seus Componentes}

Os modelos matemáticos usados para as análises de variância foram:

A) Para as análises de variância individuais ( para cada local):

$$
Y_{i j}=\mu+t_{i}+r_{j}+e_{i j}
$$


Sendo:

$$
\begin{aligned}
Y_{i j} & : \text { observação do genótipo " } \mathrm{i} \text { ", na repetição " } \mathbf{j} \text { " } \\
\mu & : \text { média geral } \\
\mathbf{t}_{\mathrm{i}} & : \text { efeito fixo de tratamentos ( genótipos ); } \mathrm{i}=1,2, \ldots \mathrm{T} \\
\mathbf{r}_{\mathrm{j}} & : \text { efeito aleatório de repetições; } \mathrm{j}=1,2, \ldots \mathrm{R} \\
\mathbf{e}_{\mathrm{ij}} & : \text { erro experimental associado à parcela " ij ". }
\end{aligned}
$$

De acordo com este modelo a análise de variância individual foi feita de segundo o esquema apresentado na Tabela 3.

Tabela 3 - Esquema de análise de variância individual para cada ambiente.

\begin{tabular}{lllll}
\hline F.V & G.L. & Q.M. & $E(Q M)$ & teste $F$ \\
\hline & & & & \\
Repetições (R) & $R-1$ & $Q_{1}$ & $\sigma_{e}^{2}+T \sigma_{r}^{2}$ & $Q_{1} / Q_{3}$ \\
Genótipos (T) & $T-1$ & $Q_{2}$ & $\sigma_{e}^{2}+R V_{t}$ & $Q_{2} / Q_{3}$ \\
Residuo & $(T-1)(R-1)$ & $Q_{3}$ & $\sigma_{e}^{2}$ & \\
\hline
\end{tabular}

Total TR-1

Onde:

$V_{t}$ : variância do efeito fixo de tratamentos ( genótipos );

$\sigma_{r}^{2}$ : variância entre repetições ( efeito aleatório );

$\sigma_{e}^{2}$ : variância do erro experimental entre parcelas ( efeito aleatório ); 
B) Para as análises de variância conjuntas:

$$
Y_{i j k}=\mu+t_{i}+r_{j(k)}+a_{k}+t_{(i k)}+e_{i j k}
$$

Sendo:

$Y_{\text {ijk }}$ : observação do genótipo " i ", na repetição " j ", no ambiente " $k$ ".

$\mu \quad$ : média geral

$t_{i}$ : efeito fixo de tratamento ( genótipos ) $; i=1,2, \ldots T$

$\gamma_{j(k)}$ : efeito aleatório da repetição "j" dentro do ambiente "k"

$a_{k}$ : efeito aleatório do ambiente ( local, ano, etc )(OBS: para o ambiente 2 este efeito é fixo ); $k=1,2, \ldots$ A

ta(ik): efeito da interação entre o genótipo "i" e o ambiente "k".

$\mathbf{e}_{\mathrm{ijk}}$ : erro experimental associado à parcela $\mathrm{ijk}$

O quadro da análise de variância, de acordo com este modelo está apresentado nas Tabelas 4 e 5, para os modelos misto e fixo, respectivamente. 
Tabela 4 - Esquema de análise de variância conjunta para os vários ambientes, considerando-se genótipos como efeito fixo e ambientes como efeito aleatório ( modelo misto ).

\begin{tabular}{lllll} 
F.V. & G.L. & QM & $E(Q M)$ & teste $F$ \\
\hline Repetições/A & $\mathrm{A}(\mathrm{R}-1)$ & $\mathrm{Q}_{1}$ & $\sigma_{\mathrm{e}}^{2}+\mathrm{T} \sigma_{\mathrm{r}}^{2}$ & $\mathrm{Q}_{1} / \mathrm{Q}_{5}$ \\
Genótipos (T) & $\mathrm{T}-1$ & $\mathrm{Q}_{2}$ & $\sigma_{\mathrm{e}}^{2}+\mathrm{R} \sigma_{\mathrm{ta}}+\mathrm{RA} \mathrm{V}_{\mathrm{t}}$ & $\mathrm{Q}_{2} / \mathrm{Q}_{4}$ \\
Ambientes (A) & $\mathrm{A}-1$ & $\mathrm{Q}_{3}$ & $\sigma_{\mathrm{e}}^{2}+\mathrm{T} \sigma_{\mathrm{r}}^{2}+\mathrm{RT} \sigma_{\mathrm{a}}^{2}$ & $\mathrm{Q}_{3} / \mathrm{Q}_{1}$ \\
TXA & $(\mathrm{T}-1)(\mathrm{A}-1)$ & $\mathrm{Q}_{4}$ & $\sigma_{\mathrm{e}}^{2}+\mathrm{R} \sigma_{\mathrm{ta}}^{2}$ & $\mathrm{Q}_{4} / \mathrm{Q}_{5}$ \\
Residuo médio & $\mathrm{A}(\mathrm{T}-1)(\mathrm{A}-1)$ & $\mathrm{Q}_{5}$ & $\sigma_{e}^{2}$ & \\
& & & & \\
\hline
\end{tabular}

\begin{tabular}{ll}
\hline Total & TRA-1
\end{tabular}

Onde:

$V_{t}$ : variância do efeito fixo de tratamentos (genótipos );

$\sigma_{\mathrm{a}}^{2}$ : variância entre ambientes ( locais e anos ); ( efeito aleatório );

$\sigma_{r}^{2}$ : variância entre repetições; ( efeito aleatório );

$\sigma_{\text {ta }}^{2}$ : variância da interação entre genótipos e ambientes; ( efeito aleatório );

$\sigma_{e}^{2}$ : variância do erro experimental; ( efeito aleatório ); 
Tabela 5 - Esquema de análise de variância conjunta para combinações envolvendo o ambiente 2, onde considera-se genótipos e ambientes como efeitos fixos ( modelo fixo).

F.V

G.L.

QM

$E(Q M)$

teste $\mathbf{F}$

Repetições/A

Genótipos (T)

Ambientes (A)

$T \times A$

Residuo Médio

$A(R-1)$

$\mathrm{T}-1$

A -1

$(T-1)(A-1)$

$A(T-1)(R-1)$

$Q_{1}$
$Q_{2}$
$Q_{3}$
$Q_{4}$
$Q_{5}$

$\sigma_{e}^{2}+T \sigma_{r}^{2}$

$\sigma_{e}^{2}+R A V_{t}$

$Q_{1} / Q_{5}$

$\sigma^{2}+T \sigma_{r}^{2}+R T V_{a}$

$Q_{3} / Q_{1}$

$\sigma_{e}^{2}+R V_{t a}$

$Q_{4} / Q_{5}$

Total

TRA - 1

Onde:

$V_{t}$ : variância do efeito fixo de tratamentos ( genótipos );

$V_{a}:$ variância do efeito fixo de ambientes;

$\sigma_{\mathrm{r}}^{2}$ : variância entre repetiçöes; ( efeito aleatório );

$V_{\text {ta }}$ : variância da interação genótipos e ambientes; ( efeito fixo );

$\sigma_{\mathrm{e}}^{2}$ : variância do erro experimental; ( efeito aleatório ); 
De acordo com o esquema das análises de variância [ Tabelas 3,4 , e 5 ( STEEL \& TORRIE, 1960 ) ] foram estimadas as variâncias genéticas entre tratamentos ( $\sigma^{2} t$ ou $\left.V_{t}\right)$, entre ambientes $\left(\sigma_{a}^{2}\right.$ ou $\left.V_{a}\right)$, da interação entre tratamentos e ambientes $\left(\sigma^{2}\right.$ ta ou $V_{\text {ta }}$ ) e do erro experimental entre parcelas $\left(\sigma_{e}^{2}\right)$, de acordo com as seguintes expressões ( itens a, b, c), operando com os quadrados médios.

a) Anava individual ( um ambiente ):

Genótipos: $\hat{V}_{t}=\frac{Q_{2}-Q_{3}}{R}$ $\hat{\sigma}_{\mathrm{e}}^{2}=\mathrm{Q}_{3}$

b) Estimativas das Anava conjunta (modelo misto ):

Genótipos: $\quad \hat{V}_{t}=\frac{Q_{2}-Q_{4}}{\text { R.A }}$

Ambientes: $\quad \hat{\sigma}_{a}^{2}=\frac{Q_{3}-Q_{1}}{T \cdot R}$

Interação: $\quad \hat{\sigma}_{\text {ta }}^{2}=\frac{Q_{4}-Q_{5}}{R}$

$\hat{\sigma}_{\mathrm{e}}^{2}=Q_{5}$ 
c) Anava Conjunta ( modelo fixo ):

Genótipos: $\quad \hat{V}_{t}=\frac{Q_{2}-Q_{5}}{R \cdot A}$

Ambientes: $\hat{V}_{\mathrm{a}}=\frac{\mathrm{Q}_{3}-\mathrm{Q}_{1}}{\text { T.R }}$

Interação: $\quad \hat{\mathrm{V}}_{\mathrm{ta}}=\frac{\mathrm{Q}_{4}-\mathrm{Q}_{5}}{\mathrm{R}}$

$\hat{\sigma}_{\mathrm{e}}^{2}=Q_{5}$

3.3 - Estimativas das Variâncias e Covariâncias Genéticas

Antes de iniciar-se a discussão das correlações propriamente ditas, cabem aqui algumas considerações sobre a natureza das variâncias e covariâncias obtidas dos dados em questão. São elas:

Considerando-se que as médias de " $T$ " tratamentos, em " $R$ " repetições de um experimento em blocos ao acaso repetido em " A " ambientes, tem-se o seguinte modelo matemático:

$$
Y_{i j k}=\mu+t_{i}+r_{j(k)}+a_{k}+t_{(i k)}+e_{i j k}
$$

Onde: 
$i=1,2,3 \ldots . T$ tratamentos

$\mathrm{j}=1,2,3 \ldots \mathrm{R}$ repetições

$k=1,2,3 \ldots$ A ambientes

Com base nisso, podemos agora considerar as seguintes situações:

Caso 01) Média de tratamentos para o caráter $X$ em um local ( $k$ ):

Modelo referente à média de várias repetições.

$\bar{x}_{i . k}=\mu+t_{i}+\bar{r}_{.(k)}+a_{k}+t_{(i k)}+\bar{e}_{(i . k)}$

A média " $\mu$ " é constante, bem como os efeitos de repetições " $\bar{r}$.(k) " e ambientes " $a_{k} "$.

Caso 2) Média de tratamentos para o caráter Y em um outro local ( $k^{\prime}$ ):

Modelo referente à média de várias repetições.

$$
\bar{Y}_{i . k}=\mu+t_{i}+\bar{r}_{.\left(k^{\prime}\right)}+a_{k^{\prime}}+t_{\left(i k^{\prime}\right)}+\bar{e}_{\left(i . k^{\prime}\right)}
$$

Aqui também média " $\mu$ " é constante, o fator repetição " $\vec{r}$.(k') " é constante e o ambiente " $a_{k^{\prime}}$ " igualmente é constante.

Portanto, uma vez que nas expressões temos os mesmos fatores constantes, a covariância do tratamento " $i$ " ( do caráter $X$ ) no ambiente " $k$ " com o tratamento " $i$ " ( do caráter $Y$ ) no ambiente " $k$ ' ", é: 


$$
\begin{aligned}
& \operatorname{COV}_{\left(\bar{X}_{i . k} ; \bar{Y}_{i . k^{\prime}}\right)}=E\left(\mu+t_{i}+t_{(i k)}+\bar{e}_{i . k}-\mu\right)_{x}\left(\mu+t_{i}+t_{\left(i k^{\prime}\right)}+\bar{e}_{i . k^{\prime}}-\mu\right)_{y} \\
& \operatorname{Cov}_{\left(\bar{X}_{i . k} ; \bar{Y}_{i . k^{\prime}}\right)}=E\left(t_{i}+t_{(i k)}+\bar{e}_{i . k}\right)_{x}\left(t_{i}+t_{\left(i k^{\prime}\right)}+\bar{e}_{i . k^{\prime}}\right)_{y}
\end{aligned}
$$

Onde:

E : esperança matemática

Convém lembrar que os ambientes em questão ( $k$ e k') são independentes, logo os componentes de interação " ta $\left({ }_{(i k)} " e\right.$ " ta(ik') ", bem como os erros experimentais $\bar{e}_{i . k}$ e $\bar{e}_{i . k}$, não são correlacionados. Em outras palavras, VENCOVSKY \& BARRIGA ( 1992 ) citam que a covariância entre as médias ajustadas dos dois locais já é de natureza genética, pois não há nada em comum entre estas que seja de natureza ambiental. Isto é, não existe correlação ambiental entre estas médias, pois elas foram obtidas em parcelas totalmente diferentes.

Logo, concluimos a partir da expressão ( 3 ), que:

a) Para dois caracteres avaliados em ambientes diferentes:

$$
\operatorname{COV}_{\left(\bar{X}_{i, k} ; \bar{Y}_{i, k^{\prime}}\right)}=E\left(t_{i}\right)_{x}\left(t_{i}\right)_{y}=\operatorname{COV}_{(x, y)}=\operatorname{cov}_{G_{(x, y)}}
$$

b) Para um mesmo caracter avaliado em ambientes diferentes:

$$
\begin{aligned}
& \operatorname{cov}_{\left(\bar{x}_{i, k} ; \bar{x}_{i, k^{\prime}}\right)}=E\left(t_{i}\right)_{x}^{2} \\
& \operatorname{cov}_{t(x, x)}=\sigma_{t}^{2}=\sigma_{G(x)}^{2}
\end{aligned}
$$


c) Por outro lado, se dois caracteres forem avaliados na mesma parcela, isto é, no mesmo ambiente ( $k=k^{0}$ ), os componentes da interação (TA) e dos erros experimentais são correlacionados, isto é:

$$
\begin{aligned}
& \operatorname{cov}_{\left(\bar{X}_{i . k} ; \bar{Y}_{i . k}\right)}=E\left(\mu+t_{i}+t_{(i k)}+\bar{e}_{i . k}-\mu\right)_{x}\left(\mu+t_{i}+t_{(i k)}+\bar{e}_{i . k}-\mu\right)_{y} \\
& \operatorname{cov}_{\left(\bar{X}_{i . k} ; \bar{Y}_{i . k}\right)}=E\left(t_{i}+t_{(i k)}+\bar{e}_{i . k}\right)_{x}\left(t_{i}+t_{(i k)}+\bar{e}_{i . k}\right)_{y}
\end{aligned}
$$

Assim:

$$
\operatorname{cov}_{\left(\bar{X}_{i . k} ; \bar{Y}_{i . k}\right)}=\operatorname{cov}_{t}+\operatorname{cov}_{t a}+\frac{\operatorname{cov}_{e}}{R}
$$

Onde:

$\operatorname{COV}_{\mathrm{t}}$ : covariância genética entre tratamentos

$\operatorname{COV}_{\text {ta }}$ : covariância da interação entre tratamentos e ambientes

$\mathrm{COV}_{\mathrm{e}}:$ covariância do erro experimental

R : número de repetições

Assim, da análise de covariância de um experimento ( dois caracteres ) repetido em um só ambiente, tem-se:

$$
\mathrm{PM}_{\mathrm{t}}-\mathrm{PM}_{\mathrm{e}}=\left(\mathrm{COV}_{\mathrm{t}}+\mathrm{COV}_{\mathrm{ta}}\right)=\mathrm{COV}_{\mathrm{t}^{\prime}}
$$

O mesmo raciocínio é válido considerando-se a análise de variância para um caráter, isto é:

$$
Q M_{t}-Q M_{e}=\left(\sigma_{t}^{2}+\sigma_{t a}^{2}\right)=\sigma_{t}^{2}
$$


Em resumo, tanto para a variância de um caráter quanto para a covariância entre dois caracteres, da análise em apenas um ambiente estima-se um componente genético $\left(\operatorname{coV}_{\mathbf{t}^{\prime}}\right.$ ou $\left.\sigma^{2} \mathrm{t}^{\prime}\right)$ inflacionado pela interação genótipos por ambiente. Quando se dispõe da avaliação em mais de um ambiente pode-se estimar um componente genético $\left(\sigma_{t}^{2}\right.$ ou $\left.\operatorname{COV}_{t}\right)$ livre da interação.

Estes procedimentos foram utilizados no presente trabalho, isto é, a obtenção de estimativas de variâncias e covariâncias genéticas livres dos componentes da interação $\left(\sigma_{\text {ta }}^{2}\right.$ ou $\left.\operatorname{COV}_{\mathrm{ta}}\right)$, no sentido de obter estimativas mais realístas e extrapoláveis. Isto somente não foi possivel para o caráter teor de proteina, devido ao fato de que dispunha-se da avaliação em apenas um ambiente.

\section{4 - Estimativas dos Coeficientes de Determinação Genotípicos ( b ), das Correlações Genéticas $\left(r_{G}\right)$ e Fenotípicas $\left(r_{F}\right)$ :}

Para todos os caracteres foram estimados os coeficientes de determinação genotípicos, utilizando-se a seguinte expressão:

$$
\hat{b}=\frac{\hat{V}_{t}}{\hat{V}_{t}+\hat{\sigma}^{2} e /(R \cdot A)}
$$

Onde:

$$
\begin{aligned}
& \hat{V}_{t}=\text { estimativa da variância genética (efeito fixo) }\left[\hat{V}_{g}=\hat{V}_{t}\right] \\
& \hat{\sigma}^{2} e=\text { estimativa da variância ambiental }
\end{aligned}
$$




$$
\begin{aligned}
& \mathrm{R}=\text { número de repetições } \\
& \mathrm{A} \quad=\text { número de ambientes }
\end{aligned}
$$

Nas diversas Anavas a fórmula acima comporta-se da seguinte forma:

a) Anava individual ( um ambiente ):

$$
\hat{b}=\frac{\hat{V}_{t}}{\hat{V}_{t}+\hat{\sigma}_{e}^{2} / R} \quad \therefore \quad \hat{b}=\frac{\hat{V}_{t}}{Q_{2} / R}
$$

Onde:

$$
\mathrm{Q}_{2}=\mathrm{QM}_{\mathrm{T}}=\text { Quadrado Médio de Tratamentos ( genótipos ) }
$$

b) Anava Conjunta Modelo Misto ( G : fixo; A : aleatório ):

$$
\hat{b}=\frac{\hat{V}_{t}}{\hat{V}_{t}+\frac{\hat{\sigma}^{2} \mathrm{ta}}{A}+\frac{\hat{\sigma}^{2} \mathrm{e}}{\mathrm{R} \cdot \mathrm{A}}} \quad \therefore \quad \hat{\mathrm{b}}=\frac{\hat{\mathrm{V}}_{\mathrm{t}}}{\mathrm{Q}_{2} /(\mathrm{R} \cdot \mathrm{A})}
$$

Onde:

$$
\hat{\sigma}^{2} \text { ta }=\text { estimativa da variância da interação entre genótipos e ambientes }
$$


c) Anava Conjunta Modelo Fixo ( $G$ : fixo; A : fixo ):

$$
\hat{b}=\frac{\hat{V}_{t}}{\hat{V}_{t}+\frac{\hat{\sigma}^{2} e}{R \cdot A}} \quad \therefore \hat{b}=\frac{\hat{V}_{t}}{Q_{2} /(R \cdot A)}
$$

Os coeficientes de correlação genéticos e fenotípicos foram estimados entre os caracteres produção de grãos ( PG ), teor de óleo ( TO ) e teor de proteína ( TP ), procurandose obtê-los a partir de avaliações dos dois caracteres em questão em ambientes diferentes, no sentido de se obter estimativas livres de componentes da interação. Para tanto, as fórmulas utilizadas foram:

$$
\begin{aligned}
& r_{G}=\frac{C \hat{O O V}_{t_{(x, y)}}}{\sqrt{\hat{V}_{t_{(x)}} \cdot \hat{V}_{t_{(y)}}}} \\
& r_{\bar{F}}=\frac{C \hat{O} V_{\bar{F}_{(x, y)}}}{\sqrt{\hat{V}_{\bar{F}_{(x)}} \cdot \hat{V}_{\bar{F}_{(y)}}}}
\end{aligned}
$$

Onde:

$\operatorname{CôV}_{t(x, y)}$ : estimativa da covariância genética entre os caracteres " $x$ " e "y" $\operatorname{côV}_{g_{(x, y)}}:=\operatorname{côV}_{t_{(x, y)}}$

$\hat{V}_{t_{(x)}} \quad$ : estimativa da variância genética do caracter " $x$ "

$\hat{\mathrm{V}}_{\mathrm{t}_{(\mathrm{y})}} \quad$ : estimativa da variância genética do caracter "y"

$r \quad$ : coeficiente de correlação entre os caracteres " $x$ " e " $y$ "

$\hat{\mathrm{V}}_{\bar{F}_{(\mathrm{x})}} \quad$ : estimativa da variância fenotípica do caráter " $\mathrm{x}$ "

$\hat{\mathrm{V}}_{\bar{F}_{(y)}} \quad:$ estimativa da variância fenotípica do caráter "y"

$\operatorname{Cô}_{\bar{F}(x, y)}$ : estimativa da covariância fenotípica entre os caracteres $x$ e $y$ 


\section{5 - Precisão das Estimativas}

A precisão das estimativas dos componentes de variância e do coeficiente de determinação genotípico foram calculados segundo VENCOVSKY \& BARRIGA ( 1992 , p. 440. ) a partir dos quadrados médios e dos graus de liberdade das fontes de variação. Segundo aqueles autores, as estimativas de parâmetros, obtidas de dados experimentais, são variáveis aleatórias, tendo portanto um erro a elas inerente. Em muitos trabalhos de pesquisa as estimativas são consideradas como parâmetros exatos e definitivos, o que na verdade não acontece.

A expressão do erro ou da variância de uma estimativa é útil no planejamento de experimentos genéticos ou na definição do processo de amostragem a ser utilizado na pesquisa. Isto é, examinando-se a expressão do erro de uma dada estimativa, pode-se verificar quais os elementos ( número de tratamentos, número de repetições, tamanho da amostra, precisão experimental, etc ) que concorrem para a redução ou minimização do referido erro. Considerando isto, pode-se planejar mais eficientemente um processo de tomada de dados num projeto de pesquisa ( VENCOVSKY \& BARRIGA 1992 ).

Seguem abaixo as expressões dos erros das estimativas:

a) Erro associado à estimativa da variância genética dos tratamentos:

$$
s_{t}=\sqrt{\hat{V}\left(\hat{V}_{t}\right)} \text {, onde }
$$


$\hat{\mathrm{V}}\left(\hat{\mathrm{V}}_{\mathrm{t}}\right)=\left[2 /(\mathrm{R} . \mathrm{A})^{2}\right] \cdot\left\{\left[\left(\mathrm{QM}_{2}\right)^{2} /\left(\mathrm{GL}_{2}+2\right)\right]+\left[\left(\mathrm{QM}_{3}\right)^{2} /\left(\mathrm{GL}_{3}+2\right)\right]\right\}$

Onde:

Para ANAVA individual: $\mathrm{QM}_{2}=\mathrm{Q}_{2}$ da Tabela 3; $\mathrm{QM}_{3}=\mathrm{Q}_{3}$ da Tabela $3\left(=\mathrm{QM}_{\mathrm{e}}\right.$ )

Para ANAVA conjunta (modelo misto ): $\mathrm{QM}_{2}=\mathrm{Q}_{2}$ da Tabela4; $\mathrm{QM}_{3}=\mathrm{Q}_{4}$ da Tabela 4

Para ANAVA conjunta ( modelo fixo ): $\mathrm{QM}_{2}=\mathrm{Q}_{2}$ da Tabela $5 ; \mathrm{QM}_{3}=\mathrm{Q}_{5}$ da Tabela 5

b) Erro associado à estimativa da variância do erro ambiental:

$s_{e}=\sqrt{\hat{V}\left(\hat{V}_{e}\right)}$, onde

$\hat{\mathrm{V}}\left(\hat{\mathrm{V}}_{\mathrm{e}}\right)=2 \cdot\left[\left(\mathrm{QM}_{\mathrm{e}}\right)^{2} /\left(\mathrm{GL}_{\mathrm{e}}+2\right)\right]$

c) Erro associado à estimativa do coeficiente de determinação genotípico:

$s_{\hat{b}}=\sqrt{\hat{v}(\hat{b})}$

$\hat{V}(\hat{b})=2(1-b)^{2}\left[\left(\frac{1}{n_{2}+2}\right)+\left(\frac{1}{n_{3}+2}\right)\right]$

Onde:

$b=$ coeficiente de determinação genotípico

Para ANAVA individual ( Tabela 3 ): $n_{2}=G L_{t} ; n_{3}=G L_{e}$

Para ANAVA conjunta $($ Tabela $4=$ modelo misto $): n_{2}=G L_{t} ; n_{3}=G L_{t a}$

Para ANAVA conjunta $($ Tabela $5=$ modelo fixo $): n_{2}=G L_{t} ; n_{3}=G L_{e}$ 


\section{RESULTADOS E DISCUSSÃO}

\section{1 - Análise Geral dos Dados: Produção de Grãos ( PG ), Teor de Óleo ( TO ) e Teor de Proteina ( TP ):}

Na Tabela 6 encontram-se os 30 genótipos estudados ( tratamentos ), com suas respectivas médias de produção de grãos por parcela ( $\mathrm{g} /$ parcela ), bem como a média geral dos ensaios e dos tratamentos utilizados nos quatro ambientes. Apresentam-se também na mesma tabela as médias do caráter teor de óleo ( $\%$ ) por parcela e as médias gerais dos três ambientes do ano agrícola 1984/85, segundo dados de SOLDINI ( 1993 ), donde foram extraídos apenas os valores que dizem respeito aos $\mathbf{3 0}$ genótipos em questão de um total de 141 materiais avaliados pelo referido autor. Ainda na mesma tabela, encontram-se os dados relativos ao teor de proteína ( $\%$ ) dos 30 genótipos, porém avaliados para esse caráter somente no ambiente 4 (ESALQ 1986/87).

Constata-se que, para o caráter produção de grãos, o melhor ambiente foi SERTÃOZINHO 84/85, apresentando a melhor média ( $1211 \mathrm{~g} /$ parcela $=2523 \mathrm{Kg} / \mathrm{ha}$ ), e 0 ambiente mais desfavorável foi ESALQ 86/87, com a menor média ( $743 \mathrm{~g} /$ parcela $=$ $1547 \mathrm{Kg} / \mathrm{ha}$ ) ( Tabela 6 e Apêndice 3 ). Sertãozinho apresentou a melhor média a despeito de apresentar solo de fertilidade intermediária, porém deve-se ressaltar aqui que, neste ambiente, as condições de precipitação pluviométrica após a semeadura, e demais fatores climáticos 
foram ideais para que houvesse perfeita germinação e, consequentemente, obtenção de um bom estande, o que proporcionou ótimo rendimento de grãos.

Quanto ao caráter teor de óleo ( TO ) destaca-se o ambiente 3 (ESALQ 84/85 ) como o de melhor média e o ambiente 2 ( SERTÃOZINHO 84/85) o de pior média. Através do teste Tukey à 5\% pode-se destacar apenas que, no ambiente 3 os genótipos, La 49-10-215, Biloxi, GO 818106, Dourados, PI 322-694, Gaúcha, SOC 81105, Ax 53-55, Batavian Yellow e BR-80-14887, foram consideravelmente piores do que os outros genótipos ( Tabela 6 ). Além disso, nesse mesmo ambiente o genótipo IAC-2 foi o que apresentou o maior teor de óleo ( $25,5 \%$ ), aliado à uma produção de grãos de $2.247,9 \mathrm{Kg} / \mathrm{ha}$.

Analisando-se o caráter teor de proteína ( média $=39,62 \%$ ), dentre os genótipos, destacaram-se Biloxi, com teor proteico médio de 46,20 \% ( média de duas repetições ); Gaúcha, com média de 45,40 \%; Ax 53-55, com 44,10 \%; La 49-10-215, com 43,05\%; Hampton, com 42,80\% e FT 10 (Princesa ), com teor de proteina de 42,70\%, constituindo-se portanto em materiais promissores. Covém lembrar Biloxi possui o tegumento da semente de cor marron, o que eventualmente poderia se tornar problemático quando analisamos o mercado de soja, onde a cor desejada é o amarelo. No entanto, isto não seria fator limitante, uma vez que o caráter cor de tegumento é de herança simples. Assim sendo, isto poderia ser facilmente corrigido.

Embora através do Teste Tukey ao nível de $5 \%$ ( Tabela 8 ), considerando-se portanto uma diferença mínima significativa ( DMS ) de $9,89 \%$, nenhum dos materiais acima tenha se revelado estatisticamente diferente dos genótipos detentores de teores proteicos próximos à média ( $39,62 \%$ ), devemos neste instante aviltar a importância estatística dos números, e passar a considerar o enorme potencial que o melhoramento desse caráter teria 
através dos materiais que se destacaram. Convém relembrar que HURBURGH et alii ( 1990 ) ressaltam a importância econômica representada pela alteração de cerca de um ponto ou ponto e meio percentual no mercado mundial de soja. Portanto, reincidindo na ênfase ao assunto, mesmo pequenos aumentos no teor proteico seriam fundamentais, a despeito de numérica e estatisticamente parecerem desprezíveis.

Convém lembrar que, dos materiais promissores nominados anteriormente, dois deles, La 49-10-215 e Gaúcha, também haviam sido aproveitados por PIMENTEL ( 1991 ) como parentais em cruzamentos que objetivavam gerar maior variabilidade para o caráter teor proteico, e com isso possibilitar o surgimento de genótipos mais ricos em proteína, e conseqüentemente futura seleção de linhagens mais avantajadas quanto à este caráter.

\section{2 - Análises de Variância}

Os tratamentos, nos diversos ambientes, apresentaram diferença estatística significativa para o caráter produção de grãos, exceto no ambiente 3 ( Tabela 7 ). 0 menor quadrado médio do residuo foi obtido no experimento SERTÃOZINHO 84/85 e o maior foi o ambiente ESALQ 84/85. A relação entre ambos quadrados médios foi de 3,71 , não ultrapassando portanto a relação de 4:1 estabelecida por Box², citado por GOMES ( 1990 ), e muito menos a relação de 7:1 sugerida por BANZATTO \& KRONKA ( 1989 ) para a realização da análise conjunta. Isto é, a relação de 3,71 entre os quadrados médios extremos

${ }^{2}$ BOX, G.E.P. Some theorems on quadratic forms applied in the study of analysis of variance problems, I. Ann. Math. Stat., 25:290-302, 1954. 
nos dá uma indicação da homogeneidade dos ambientes, e portanto indica que são passiveis de serem submetidos à análises conjuntas.

Observando-se a mesma tabela, verifica-se que os coeficientes de variação estiveram abaixo de $20 \%$, valor este que pode ser considerado como aceitável para o caráter produção de grãos em soja. Cabe salientar que, os ambientes 2 e 4, citados anteriormente como sendo respectivamente os ambientes de maior e menor produção de grãos, detêm também respectivamente o menor $(9,54 \%)$ e o maior $(18,92 \%)$ coeficiente de variação. Valores semelhantes foram obtidos por SOLDINI ( 1993$)(12,44 \%$ à $22,37 \%$ ) trabalhando com três grupos de maturação e uma quantidade maior de genótipos, dos quais apenas 30 participaram do presente estudo. Também PULCINELLI ( 1992 ) e PIMENTEL ( 1991 ) obtiveram coeficientes de variação semelhantes para produção de grãos nesta espécie: 21,6 à 25,3 , e $20,95 \%$, respectivamente, sendo que o primeiro apresentou coeficiente maior por ter utilizado germoplasma exótico, não adaptado às condições de cultivo dos ensaios, sendo mais sensivel às variações ambientais.

Para o caráter teor de óleo ( TO ), verifica-se que nas análises de variância individuais os genótipos diferem estatisticamente a $1 \%$ nos três ambientes do ano agrícola 1984/ 85 ( Tabela 8 ). Observa-se, que os experimentos apresentaram coeficientes de variação de $2,45 \%$ à $3,74 \%$ ( Tabela 8 ), valores estes podendo ser considerados como normais e condizentes com os dados reportados pela literatura, uma vez que se trata de um caráter de alta herdabilidade, logo, pouco sujeito às influências ambientais e portanto pouco sujeito à variações que poderiam estimular a elevação do C.V.. SOLDINI ( 1993 ) trabalhando com 141 genótipos, incluindo os $\mathbf{3 0}$ materiais usados neste estudo, obteve coeficientes de variação oscilando de 2,49 \% a 3,39 \% nos grupos de maturação precoce e intermediário. 
O teor de proteína ( $\%$ ) foi estudado no ambiente 4 ( ESALQ 86/87) sendo que houve diferença significativa à $1 \%$ entre os genótipos ( Tabela 8 ), obtendo-se uma média de $39,62 \%$ de proteína nos grãos, com um coeficiente de variação experimental de $6,04 \%$. Diante desta magnitude atribuida ao C.V. pode-se considerar este experimento como estando dentro do que se esperaria como normal, uma vez que, do mesmo modo que TO, trata-se de um caráter pouco influenciado pelo ambiente. Resultados semelhantes foram obtidos por PULCINELLI ( 1992 ), que chegou a magnitudes de $3,8 \%$ e $4,4 \%$ para o $\mathrm{CV}$.

Na Tabela 9 encontram-se os quadrados médios para os ambientes individualmente ( ANAVAS individuais ) e para várias combinações destes ( ANAVAS conjuntas ), para os três caracteres em estudo. Observando-se os ambientes um a um, verificase que para o caráter produção de grãos há diferença significativa entre tratamentos em todos os ambientes, exceto no ambiente 3, como já citado anteriormente.

Considerando-se as análises conjuntas, todas as combinações de ambientes para PG apresentam significância quanto à diferença estatística entre tratamentos, exceto as análises conjuntas dos ambientes $1 \times 3$ e $2 \times 3$, que não foram significativas. Nas análises conjuntas, os ambientes que demonstraram ser estatisticamente diferentes foram: $1 \times 2,1 \times 3$, $2 \times 4,3 \times 4$ e $1 \times 3 \times 4$. Já a interação entre tratamentos (genótipos ) e ambientes, para 0 caráter PG, foi significativa ao nível de $1 \%$ ou $5 \%$, exceto para as análises $1 \times 3$ e $3 \times 4$. Percebe-se que a significância para interação ocorreu em todas as oportunidades em que o ambiente 2 ( SERTÃOZINHO 84/85 ) teve participação nas análises, ocorrendo também para as análises $1 \times 4$ e $1 \times 3 \times 4$. Esta significância quando da participação do ambiente 2 será discutida no ítem caracterização dos ambientes. 
Para o caráter teor de óleo ( TO ), do mesmo modo que nas análises de variância individuais, nas análises conjuntas também verifica-se que os genótipos diferem estatisticamente a $1 \%$ nos três ambientes do ano agrícola 1984/85 (Tabela 9 ). Visto que, nas análises conjuntas os ambientes também diferiram entre si estatisticamente, decorre daí que o ambiente afetou o teor de óleo dos genótipos sobremaneira. $O$ ambiente não somente afeta 0 caráter TO mas inclusive demonstra interagir significativamente com os genótipos ( interação genótipo $\times$ ambiente $=T \times A$ ) em todas as análises conjuntas ( Tabela 9 ), exceto na análise $2 \times 3$; ou seja, exceto considerando-se $2 \times 3$, as outras combinações proporcionaram significativas alterações no grau de superioridade ou na ordem de classificação dos genótipos quanto ao teor de óleo das sementes.

Entretanto, a importância da existência de significância estatística para a interação Tratamentos $\times$ Ambientes ( $T$ × A ) não deve ser supervalorizada pois VENCOVSKY \& BARRIGA ( 1992, p. 239 ) consideram que a significância na fonte de variação da interação é importante no melhoramento mas " não nos diz muito ". Para entenderse este aspecto, vejam-se os seguintes desdobramentos feitos pelos autores a partir das esperanças matemáticas de experimentos conduzidos em blocos ao acaso. Ressalta-se que os tratamentos genéticos eram comuns aos dois experimentos. Das análises de variância ( ANAVAS ) individuais, ou seja, por experimento, obtem-se, através da esperança matemática dos quadrados médios dos dois experimentos, $\sigma^{2} \mathrm{t}_{1}$ e $\sigma_{\mathrm{t} 2}^{2}$, sendo respectivamente, variância de tratamentos ( genética ) no experimento 1 ( ambiente 1 ), e variância de tratamentos ( genética ) no experimento 2 ( ambiente 2 ). Já a partir da ANAVA conjunta obtem-se uma variância genética que abrange os dois ambientes simultaneamente $\left(\sigma_{t}^{2}\right)$.

Assim sendo, as variâncias citadas relacionam-se como segue: 


$$
\begin{aligned}
& \sigma^{2}+\sigma^{2} \mathrm{ta}=\left(\frac{1}{2}\right)\left(\sigma^{2} \mathrm{t}_{1}+\sigma^{2} \mathrm{t}_{2}\right)=\overline{\sigma^{2}} \mathrm{t} \\
& \sigma_{\mathrm{t}}^{2}=\overline{\sigma^{2} \mathrm{t}-\sigma_{\mathrm{ta}}^{2}}
\end{aligned}
$$

A partir da expressão ( 4 ), os autores esclarecem que $\sigma^{2}$ representa a variância genética que permite um melhoramento abrangendo todos os ambientes simultaneamente. Além disso, comentam que a variância de tratamentos pode ser nula, mesmo que detecte-se variâncias genéticas dentro dos ambientes, cuja média é $\overline{\sigma^{2}} \mathrm{t}$. Tudo dependerá da magnitude da variância de interação, $\sigma^{2}$ ta .

Também:

$$
\sigma_{\mathrm{ta}}^{2}=\frac{1}{2}\left(\sigma_{\mathrm{t}_{1}}-\sigma_{\mathrm{t}_{2}}\right)^{2}+\left(1-\rho_{12}\right) \sigma_{\mathrm{t}_{1}} \cdot \sigma_{\mathrm{t}_{2}} \quad[\mathrm{5}]
$$

Para I ambientes:

$$
\sigma^{2}{ }_{t a}=\frac{1}{2} \sum_{j<j^{\prime}}^{I}\left[\left(\sigma T_{j}-\sigma T_{j}^{\prime}\right)^{2}+\left(I-\rho_{j j^{\prime}}\right) \sigma T_{j} \sigma T_{j^{\prime}}\right]
$$

Onde:

$\rho_{i j^{\prime}}=$ correlação dos tratamentos entre os ambientes j e j'.

Logo, as expressões ( 5 ) e ( 6 ) mostram que a variância da interação ( $\sigma^{2}$ ta $)$ é composta de duas partes, quais sejam : a) Uma devida às diferenças na variabilidade genética dentro de ambientes, como representado por $\left(\sigma_{\mathrm{t} 1}-\sigma_{\mathrm{t} 2}\right)$ b) Outra advinda da falta de uma 
correlação linear perfeita entre os tratamentos genéticos, de um ambiente para outro $\left(\sigma_{\mathrm{t} 1} \sigma_{\mathfrak{t} 2}\left(1-\rho_{12}\right)\right)$. VENCOVSKY \& BARRIGA ( 1992$)$ chamam a atenção para o fato de que deve-se notar ser a segunda a parte problemática da interação, pois uma baixa correlação, $\rho_{12}$, deve significar que o material genético superior num ambiente pode não sê-lo em outro. No entanto, a interação pode existir mesmo com alta correlação. Neste caso não teremos dificuldades numa seleção, a despeito de termos $\sigma^{2}$ ta presente, pois neste caso, a interação só diz respeito ao grau de superioridade dos genótipos de um ambiente para outro, não afetando a ordem de classificação dos genótipos.

\section{3 - Caracterização dos Ambientes}

Já mencionou-se anteriormente que os quatro ambientes, quanto aos quadrados médios da produção de grãos, podem ser considerados homogêneos ( Tabela 7 ). Entretanto, analisando-se a Tabela 9 , verifica-se que a interação entre tratamentos ( genótipos ) e ambientes, para o caráter produção de grãos, foi significativa em todas as oportunidades em que o ambiente 2 ( SERTÃOZINHO 84/85) teve participação nas análises.

Reforçando esta observação, verifica-se no Apêndice 1, que as estimativas da variância de interação ( $T \times A$ ) com maior magnitude foram aquelas que envolveram o mencionado ambiente $2(1 \times 2,2 \times 3$, e $2 \times 4$ ), fato este também observado na Tabela 9 , onde pode-se notar a tendência de predominarem valores maiores para os quadrados médios nas ANAVAS conjuntas que envolveram o ambiente 2. O mesmo ocorre nas análises de três ambientes, onde a análise conjunta $1 \times 3 \times 4$ tem 0 mais baixo valor da variância de interação tratamentos $x$ ambientes uma vez que não envolve 0 ambiente 2 . Nas análises conjuntas de experimentos ( Tabela 9 ) pode-se notar que, nos ambientes $2 \times 3$ e $2 \times 4$, o valor 
do quadrado médio da interação supera o valor do quadrado médio de tratamentos. Logo, nesse caso, a estimativa da variância genética seria negativa considerando-se o modelo aleatório, o que seria indesejável. Assim, o ambiente SERTÃOZINHO 84/85 ( 2 ) foi considerado fixo, e portanto, o teste $F$ foi procedido com o QM do erro experimental, e a variância genética também foi calculada através do erro.

$$
\begin{aligned}
& \text { Modelo Misto: } V_{t}=\frac{Q M_{\text {trat. }}-Q_{\text {txa }}}{\text { R.A }} \\
& \text { Modelo Fixo : } V_{t}=\frac{Q M_{\text {trat. }}-Q M_{\text {erro }}}{\text { R.A }}
\end{aligned}
$$

Sendo que:

Modelo Misto: para os Ambientes 1, 3 e 4.

Modelo Fixo: para o Ambiente 2

Assim, estes resultados indicam que o referido ambiente é distoante em relação aos demais, porém não se trata de um ambiente adverso para a cultura da soja, uma vez que apresentou a melhor média e o menor coeficiente de variação para o caráter produção de grãos ( Tabela 7 ).

Outro aspecto, que realça a diferença do ambiente 2 em relação aos demais, pode ser observado no Apêndice 2, onde verifica-se que as correlações referentes ao desempenho dos genótipos nos 4 ambientes varia de $-0,48$, quando analisamos os ambientes SERTÃOZINHO 84/85 X ESALQ 86/87, à +0,70 nos ambientes ESALQ 84/85 X ESALQ 86/87 ( média de $+0,23$ ) para o caráter produção de grãos, correlação esta que se elevaria ao 
patamar de +0,65 ( média ) caso o ambiente 2 não estivesse incluido. Assim, pode-se esperar que, na maior parte dos casos, o desempenho dos genótipos num dos ambientes se repita nos demais, considerando somente os ambientes 1, 3 e 4. Além disso, a correlação do ambiente 2 com os outros três ambientes (Apêndice 2 ) varia de $-0,48$ a $+0,06$, ou seja, a correlação é baixa ou mesmo negativa, donde conclui-se que no ambiente 2 os genótipos assumem um comportamento cujo padrão é totalmente diferente do verificado nos outros ambientes.

Já as correlações relativas ao teor de óleo (\%), expressas também no Apêndice 2, estão de acordo com os valores esperados, isto é, que o teor de óleo não varie muito de um ambiente para outro. As correlações variando de $+0,81$ a +0,93 confirmam portanto, esta expectativa. Novamente convém lembrar que os dados, quanto ao teor de óleo, foram extraídos de SOLDINI ( 1993 ).

Diante desta constatação, classificou-se o ambiente 2 como ambiente discrepante e, conseqüentemente, este deveria ser retirado do grupo dos demais, para que o fator ambiente continuasse sendo considerado como fator aleatório. Convém ressaltar que o ambiente em questão surge como distoante a despeito da comparação dos valores extremos dos quadrados médios dos resíduos das análises individuais não ter detectado anormalidades entre os experimentos, como também já mencionado neste capítulo. Porém com a retirada do ambiente 2 do conjunto de dados analisados, gera-se 0 inconveniente de se perderem informações. Optou-se portanto por mantê-lo nas análises, assumindo o fator ambiente ( para o ambiente 2 ) como fixo, por ser um ambiente distoante.

Resumidamente, podemos concluir dizendo que adotou-se um modelo estatístico misto, onde os ambientes 1, 3 e 4 foram considerados como um fator aleatório, por representarem uma região ecológica ( região de Piracicaba ), como citam VENCOVSKY \& 
BARRIGA ( 1992 ); e os genótipos, representados por 30 linhagens de soja, foram considerados como fator fixo. A adoção do fator ambiente como sendo aleatório ocorreu devido ao fato de que os ambientes em questão representam uma região ecológica homogênea porém restrita, e portanto não permitem inferências para áreas além delas próprias. Por outro lado, 0 ambiente 2 foi considerado como fixo por contrastar demais com os outros.

\section{4 - As Estimativas das Variâncias}

Observa-se na Tabela 10 as estimativas das variâncias genéticas, e a estimativa de seus respectivos desvios, bem como as variâncias ambientais ( variâncias do erro experimental ) e respectivos desvios, em cada um dos ambientes ( ANAVAS individuais ) e suas combinações ( ANAVAS Conjuntas), calculados conforme VENCOVSKY \& BARRIGA ( 1992 , p. 440 ) a partir dos quadrados médios e dos graus de liberdade das fontes de variação.

Lembrando as considerações feitas no capítulo Materiais e Métodos ( ítem 3.3 - Estimativas das Variâncias e Covariâncias Genéticas, p.46 ), verifica-se que as estimativas das variâncias genéticas ( para PG ) obtidas nas análises individuais dos experimentos são estimativas inflacionadas pela interação $T \times A$, que, não podendo ser isolada do fator de variação " tratamentos ", aparece junto ao quadrado médio de tratamentos, superestimando deste modo a estimativa da variância genética. Já aquelas estimativas de variâncias genéticas obtidas a partir das análises de variância conjuntas ( ano 84/85 versus ano 86/87 ) estão livres desta interação conforme explicam VENCOVSKY \& BARRIGA ( 1992 ), sendo denominadas, no presente estudo, de estimativas de variâncias genéticas " limpas ". Confirmando esta predição, observa-se também no presente estudo que as variâncias 
genéticas das análises individuais são consideravelmente maiores do que as variâncias genéticas das análises conjuntas para 0 caráter $P G$, visto que as primeiras certamente apresentam um considerável aporte devido à grande magnitude da interação, imbutida nas mesmas ( Tabela 10 ). Assim, usando-se as variâncias genéticas das análises conjuntas, temse a oportunidade de trabalhar com estimativas mais confiáveis das variâncias genéticas.

O mesmo ocorre para 0 teor de óleo, onde as estimativas das variâncias genéticas dos ambientes 1,2 e 3, apresentadas na Tabela 10 estão inflacionadas pela interação agregada ao valor do quadrado médio de tratamentos. As exceções são as análises conjuntas das combinações $1 \times 3,1 \times 2$ e $2 \times 3$, que permitem, segundo VENCOVSKY \& BARRIGA ( 1992 ), a obtenção de estimativas limpas, uma vez que são estimadas através de dois ambientes independentes.

Quanto ao teor de proteína, não pôde-se obter nenhuma estimativa de $V_{t}$ limpa ( variância genética limpa ) uma vez que este caráter só foi avaliado em um ambiente, qual seja, ESALQ 86/87, e portanto a estimativa que temos a disposição é aquela que inclui a interação, atingindo o valor de 5,94 ( $s=2,35$ ) ( Tabela 10 ) e uma média de $39,62 \%$ de proteina ( Tabela 8 ).

Entretanto, convém ressaltar que a magnitude da estimativa da Ve para teor proteico é praticamente da mesma ordem que à estimativa da $V_{t}$, enquanto que para teor de óleo a média $(0,51)$ das estimativas de. Ve das análises individuais e conjuntas chega a representar somente um terço da magnitude da $V_{t}$ de tais ANAVAS. Isto é, neste estudo, teor proteico é um caráter que possui uma Ve de magnitude semelhante à $V_{t}$, e o teor de óleo tem uma variância genética três vezes superior à Ve. Disto decorre que a seleção para proteína, nos genótipos e nos ambientes citados no presente estudo, será menos eficiente do 
que a seleção para teor de óleo. As relações entre as magnitudes destas variâncias terão implicações sobre o cálculo do coeficiente de determinação genotípico, que será tratado oportunamente.

Quanto à precisão das estimativas das variâncias a literatura não oferece muitos subsídios, além do que este não é o alvo principal deste estudo. Assim sendo, não se pode fazer afirmações seguras, mas sabe-se que às estimativas obtidas por meio de componentes de variância ( variância, herdabilidade, e outros ) estão associados erros relativamente elevados em muitos casos ( GORDON et alii, 1972; VELLO \& VENCOVSKY, $1974)$. O maior erro detectado $(122,61 \%)$, referente à estimativa da variância genética $\left(V_{t}\right)$ no ambiente 3 ( Tabela 10 ), decorre do fato de que o erro associado à estimativa é maior do que a própria estimativa, o que é consequência de um quadrado médio não significativo estatisticamente quando aplicado o Teste F. Fato idêntico acontece com a análise conjunta $2 \times 3$. Para o teor proteico o erro associado ( média ) à estimativa da variância genética foi de $29 \%$, enquanto que para o teor proteico este valor foi de $39,5 \%$. Já o desvio padrão associado à estimativa da variância ambiental para PG variou de $14,9 \%$ a $25,4 \%$, enquanto que para teor de óleo atingiu um valor mínimo de $17,2 \%$ e um máximo de $26 \%$. Para teor proteico o desvio associado foi de $25,3 \%$, podendo-se assim considerar tais estimativas com precisão satisfatória.

\section{5 - Coeficiente de Determinação Genotípico}

O coeficiente de determinação genotípico expressa o grau no qual os fenótipos são determinados pelos genótipos ( FALCONER, 1987 ). Quando os individuos em estudo compreendem uma amostra aleatória de uma população genética ( relacionados 
reprodutivamente ), o coeficiente de determinação genotípico corresponde ao coeficiente de herdabilidade. Em caso contrário, como no presente estudo, utiliza-se o termo coeficiente de determinação genotípico.

Os valores relativamente altos destes coeficientes de determinação genotípicos, indicam a importância das causas genéticas na variação fenotípica do caráter. Estes coeficientes ( Tabela 11 ) superestimam o verdadeiro valor da contribuição genotípica, uma vez que estão inflacionados pelos efeitos das interações genótipos $x$ ambientes nas analises de variância individuais, exceto nas ANAVAS conjuntas, onde as estimativas das variâncias genéticas obtidas são consideradas limpas, como já discutimos anteriormente. Entretanto, a despeito disso, eles oferecem uma idéia relativa sobre as dificuldades ou facilidades existentes no melhoramento dos caracteres em estudo.

Considerando-se o presente trabalho, verifica-se que o coeficiente de determinação genotípico variou de 0,61 a 0,75 ( média $b=0,66$ ) para 0 caráter produção de grãos ( $P G$ ) nos quatro ambientes tomados independentemente, porém associado à um desvio da ordem de $23,0 \%$ a $11,9 \%$ respectivamente ( Tabela 11 ). Neste caso, está sendo desconsiderado o ambiente 3 para o qual não houve significância quanto à fonte de variação tratamentos na Tabela 7, uma vez que apresentou também um erro associado à estimativa do " b " muito elevado ( $103,3 \%$ ). Nas análises conjuntas do mesmo caráter, o coeficiente variou de 0,47 a 0,63 ( média $b=0,57$ ), sendo que neste caso o desvio variou de $40,3 \%$ a $20,9 \%$. Neste caso desconsiderou-se as ANAVAS conjuntas $1 \times 3$ e $2 \times 3$, para as quais também não houve significância na fonte de variação "tratamentos", além de apresentarem erros elevados associados à estimativa do " b " ( 54,2 \% e 65,9 \% ). No entanto, as análises conjuntas representam estimativas mais limpas do coeficiente de determinação genotípico "b", uma vez que são calculadas a partir da estimativa da Variância Genética $\left(V g=V_{t}\right.$ da análise 
de variância ) limpa da influência da interação $T \times A$. Conforme VENCOVSKY \& BARRIGA ( 1992, p. 266 ) a covariância entre as médias ajustadas de dois locais já é de natureza genética, pois não há nada de comum entre estas que seja de natureza ambiental. Citam ainda os autores, que não existe correlação ambiental entre estas médias, pois elas foram obtidas em parcelas totalmente diferentes. Ora, considerando isto, sabemos que se a covariância é calculada para o mesmo caráter em ambientes diferentes, ter-se-á a própria variância, que passa a ser a variância genética.

Voltando-se novamente a considerar as magnitudes dos coeficientes de determinação genotípicos descritos acima, para o caráter PG, verifica-se que estes são confirmados por diversos autores, entre eles: SHARMA et alii ( 1986 ) que obtiveram uma herdabilidade de 31,1\% para PG; OPENSHAW \& HADLEY ( 1981 ) obtiveram herdabilidade variando de $3 \%$ a $58 \%$; MONTEVERDE ( 1984 ) obteve herdabilidades da ordem de $54 \%, 34$ $\%$ e $11 \%$, em três populações.

Considerando agora o caráter teor de óleo, percebe-se que este, no presente estudo, é um caráter menos influenciado pelo ambiente, uma vez que os coeficientes de determinação genotípicos foram de $0,93,0,84$ e 0,85 (média $b=0,88$ ) respectivamente para os ambientes ANHEMBI 84/85, SERTÃOZINHO 84/85 e ESALQ 84/85, sendo que os respectivos desvios foram da ordem de 2,68 \%, 6,85 \% e 6,38 \%. Nas análises conjuntas para teor de óleo obteve-se um " b " médio de 0,89. Estes valores dos coeficientes de determinação genotípicos também são semelhantes aos encontrados por McKENDRY et alii ( 1985 ) que obteve herdabilidades no sentido amplo e restrito parecidas, variando de $58 \%$ a $68 \%$. Já SHARMA et alii ( 1986 ) obtiveram uma herdabilidade menor ( $43,9 \%$ ) para TO. OPENSHAW \& HADLEY ( 1981 ) estimaram a herdabilidade para TO em $51 \%$, no entanto, OPENSHAW \& HADLEY ( 1984 ) chegaram a magnitudes mais próximas às do presente estudo, atingindo 
valores de $93 \%( \pm 0,01)$ em uma das populações estudadas, e $71 \%( \pm 0,03)$ numa segunda população. Também CHEN ( 1987 ) obteve estimativas de herdabilidade maiores do que $80 \%$ para este caráter.

Para o caráter teor de proteína o coeficiente de determinação foi de 0,67 ( Ambiente ESALQ 86/87), com um desvio de 17,30 \%. OPENSHAW \& HADLEY ( 1981 ) estimaram coeficientes de herdabilidade para TP que oscilavam de $57 \%$ a $90 \%$. Ainda OPENSHAW \& HADLEY ( 1984 ) obtiveram estimativas da herdabilidade deste caráter da ordem de $90 \%( \pm 0,02)$ numa das populações estudadas, e $75 \%( \pm 0,03)$ em outra população. CHEN ( 1987 ) também obteve para este caráter estimativa de herdabilidade superior à $80 \%$, enquanto McKENDRY et alii ( 1985 ) obtiveram uma herdabilidade no sentido amplo ( geração F2 ) variando de 76 \% a 83 \%. Porém SHARMA et alii ( 1986 ) alcançaram resultados de magnitude menor $(41,9 \%)$, enquanto o coeficiente de herdabilidade encontrado por SURLAN-MOMIROVIC ( $1987 \mathrm{~b}$ ) foi bem mais elevado $(83,1 \%)$.

Também observa-se que o coeficiente de determinação genotípico ( b ) do teor de proteina é menor $(0,67)$ do que o coeficiente do teor de óleo ( 0,85 a 0,93). Assim, neste estudo, verifica-se que o teor de óleo esta menos sujeito às influências ambientais do que o teor de proteína, portanto, fica claro que uma eventual seleção para proteína, considerando-se os genótipos e ambientes estudados, será menos eficiente do que a seleção para teor de óleo, como já mencionado em ítem anterior.

Quanto ao erro associado ao coeficiente de determinação genotípico ( b ), verifica-se que o mesmo apresentou uma amplitude de $11,9 \%$ a $54,2 \%$ (para PG ), portanto, uma média de $23,71 \%$. É preciso salientar que os desvios dos ambientes $3(103,3 \%), 1 \times 3$ $(54,2 \%)$ e $2 \times 3(65,9 \%)$ em relação ao coeficiente " b ", foram desconsiderados no cálculo 
desta média, uma vez que estes ambientes já não apresentavam significância para tratamentos na análise de variância. Bogyo ${ }^{3}$, citado por GERALDI ( 1977 ), admite, arbitrariamente, um coeficiente de variação de $25 \%$ como valor aceitável para o coeficiente de herdabilidade, ao passo que coeficientes de variação obtidos por outros autores são geralmente mais altos, como cita GERALDI ( 1977 ). No entanto, o desvio do coeficiente " b " constatado para o caráter TO foi de ordem bem inferior, variando de 2,45 \% a um máximo de 6,94 \% (média de $4,78 \%$ ), enquanto que para TP esse desvio foi de $17,28 \%$, portanto, maior do que o primeiro.

Considerando tais resultados, pode-se admitir que, as estimativas das variâncias genéticas, ambientais e os coeficientes " b " foram obtidos com boa precisão, exceção feita ao " b " da produção de grãos, o qual poderiamos considerar apenas razoável ( desvio médio de $23,71 \%$ ), porém não comprometedor.

Conseqüentemente os resultados obtidos neste estudo estão dentro do esperado, isto é, os resultados estão condizentes com os dados da literatura, sendo que a produção de grãos é um caráter mais influenciado pelo ambiente do que os caracteres Teor de Óleo e Teor de Proteína.

\section{6 - Associação entre Caracteres:}

Segundo VENCOVSKY \& BARRIGA ( 1992 ), o estudo da natureza e magnitude das relações existentes entre caracteres é importante visto que no melhoramento

${ }^{3}$ BOGYO, T.P. Coeficients of variation of heritability estimates obtained from variance analyses. Biometrics, Raleigh, 20 (1): 122-29, 1964. 
em geral, a preocupação é aprimorar o material genético, não para caracteres isolados, mas para um conjunto destes, simultaneamente. Ou seja, é sempre útil considerar-se as implicações do melhoramento de uma característica sobre outra.

Discutir-se-á a partir deste momento, três Tabelas (12, 13 e 14 ) referentes às correlações de caracteres dois a dois, cada um dos quais avaliados em anos agrícolas diferentes, e que portanto, como já explicado anteriormente, oferecem uma covariância genética " limpa " e variância genética " limpa " ( para o caráter produção de grãos ), isto é, livre dos efeitos de interação com o ambiente, que superestimam a covariância e variância. Isto permite obter valores mais precisos de correlação genética, a despeito das correlações fenotipicas apresentadas nas mesmas tabelas.

Assim, estimativas das correlações genéticas entre os caracteres teor de óleo ( $84 / 85$ nos três ambientes ) e produção de grãos ( $86 / 87$ ) foram de $0,38,0,13$ e 0,15 respectivamente para os ambientes ANHEMBI, SERTÃOZINHO e ESALQ comparados com 0 ambiente ESALQ 86/87. As correlações fenotipicas, apresentaram respectivamente os seguintes valores: $0,22,0,04$, e 0,07 , portanto, consideravelmente menores que os primeiros. $\mathrm{Na}$ Tabela 12 indica-se ainda os valores médios entre os ambientes 1 e 3, ou seja, foi calculada uma correlação genética a partir de uma análise de variância conjunta dos ambientes 1 com 3 (para TO) e entre os ambientes 1, 3 e 4 ( para PG) obtendo-se o valor de 0,33, e uma correlação fenotípica ( $r_{F}$ ) calculada do mesmo modo, da ordem de 0,38 .

Neste caso, calcularam-se as correlações a partir de covariâncias e variâncias genéticas " limpas " ( para o caráter produção de grãos ). Desconsiderando-se o ambiente problemático, SERTÃOZINHO, obteve-se uma correlação genética média de 0,33 entre o teor de óleo ( $84 / 85$ ) e a produção de grãos ( $86 / 87$ ). Quanto ao grau de associação destes dois 
caracteres, resultados semelhantes foram obtidos por diversos pesquisadores, entre os quais estão MAYOR \& SOTO ( 1985 ) cujos valores de correlação entre produção de grãos e teor de óleo foram de $+0,12$ no verão e $+0,49$ no inverno. No entanto SURLAN-MOMIROVIC ( 1987b ) obteve estimativas negativas para esta correlação ( $-0,50)$, bem como BURTON ( 1987$)$, cujas estimativas variaram de $-0,27$ a $+0,45$. Também XU \& WILCOX ( 1992 ) observaram coeficientes de correlação entre TO e PG variando de $-0,26$ a $+0,27$. Ou seja, verifica-se na literatura, grande variação na magnitude da correlação entre PG e TO, entretanto convém salientar que são predominantes os dados que dão como positiva a relação de associação entre estes dois caracteres, sendo que isto é confirmado pelo fato de que o melhoramento da soja para produção de grãos tem levado, via de regra, historicamente, à aumentos no teor de óleo.

Quanto aos caracteres teor de óleo ( $84 / 85$ ) e teor de proteína ( $86 / 87$ ), as correlações genéticas encontradas ( Tabela 13 ) são de caráter negativo, como era esperado, sendo o valor médio entre os ambiente "1 1 " e " 4 " de $-0,31$. Para os três ambientes de 84/85 em relação ao ambiente de $86 / 87$, as correlações genéticas foram as seguintes: $-0,43$; $-0,28$, e -0,12, respectivamente para ANHEMBI, SERTÃOZINHO e ESALQ. Os valores das correlações fenotípicas para esses casos são : $-0,34,-0,21$ e $-0,09$. A correlação genética média, assim como a fenotípica média, foram calculadas com base numa ANAVA conjunta do teor de óleo dos ambientes 1 e 3 em relação ao teor de proteína do ambiente 4. Neste caso, enfatiza-se que, a correlação genética média $(-0,31)$ foi superior à correlação fenotípica média $(-0,23)$.

Deve-se ainda lembrar que, a variância genética média de ANHEMBI ( 1 ) e ESALQ 84/85 ( 3 ) não corresponde a média aritmética de 1,92 e 1,80 ( Tabela 13 ), e sim corresponde à covariância entre estes dois ambientes para o caráter teor de óleo ( 1,51$)$. Esta 
variância é genética e livre da distorção causada pela interação, uma vez que a covariância está sendo feita de um ambiente para outro. Logo o valor é 1,51.

Confirmando os resultados encontrados no presente estudo quanto à associação entre TO e TP, encontram-se na literatura os dados obtidos por JOHNSON et alii ( 1955 ), um dos primeiros grupos de pesquisadores a preocupar-se com as questões relativas à associação de caracteres e suas consequências no melhoramento da soja, cujos valores da correlação genética entre TO e TP variaram de $-0,69$ a $-0,70$ para uma das populações estudadas, e -0,48 para a outra população. SHANNON et alii ( 1972 ) observaram correlações genéticas altamente significativas e negativas em seis populações $(r=-0,46$ a $r=-0,92)$. Igualmente SHORTER et alii ( 1977 ) obtiveram correlaçōes fenotípicas e genotípicas negativas em dois dos cruzamentos estudados ( $-0,62$ a $-0,96)$ e bastante menores no terceiro ( $-0,24$ a $-0,35$ ). SIMPSON \& WILCOX ( 1983 ) obtiveram uma correlação genética entre TO e TP que variava de -0,15 a -0,96. OPENSHAW \& HADLEY ( 1984 ) trabalharam com duas populações, obtendo da primeira uma correlação fenotípica de $-0,80$, e genotípica de valor igual a $-0,83$, enquanto que na segunda população esta última alcançava o valor algo menor ( $-0,68)$. Entretanto MAYOR \& SOTO ( 1985 ) encontraram correlação de $+0,10$ no verão e $+0,43$ no inverno, sendo que outro estudo dos mesmos pesquisadores revelou também uma correlação positiva $(+0,14)$ entre estes dois caracteres usualmente associados negativamente. Alguns outros estudos também revelam a inversão da associação, como no caso de HUANG \& TONG ( 1990 ), cujos dados revelaram uma correlação de $+0,14$ nos genótipos selvagens e +0,62 nos semi-selvagens. SURLAN-MOMIROVIC ( $1987 \mathrm{~b}$ ) obteve correlação negativa ( $-0,32)$. VASHCHENKO et alii ( 1989$)$ obtiveram também correlações negativas $(-0,26)$ num grupo semi-precoce , e tardio $(-0,72)$, do mesmo modo que XU \& WILCOX (1992) $(r=-0,61$ a $-0,88)$. Portanto, verifica-se que a grande maioria dos estudos 
reportados na literatura mostram que a associação entre teor de óleo e teor de proteína é negativa, apesar do registro de algumas exceções.

As correlações genéticas entre PG ( $84 / 85$ ) e TP ( $86 / 87$ ) foram de $-0,31$ entre ANHEMBI 84/85 e ESALQ 86/87; -0,38 entre SERTÃOZINHO 84/85 e ESALQ 86/87; e $-0,58$ entre ESALQ 84/85 e ESALQ 86/87 (Tabela 14 ). Os coeficientes citados, bem como o coeficiente médio de correlação genética foi de $-0,47$. Tais magnitudes encontram respaldo em dados da literatura. JOHNSON et alii ( 1955 ) foram pioneiros no estudo da relação entre os dois caracteres, tendo obtido uma correlação que variou de $-0,08$ a $-0,64$ em duas populações. Também SHANNON et alii ( 1972 ) estudou três populações obtendo coeficientes de $-0,28$, $-0,55$ e $+0,61$, respectivamente. Nota-se uma grande variação no grau de associação bem como no tipo de associação, o que se confirma também com os dados obtidos por SIMPSON \& WILCOX ( 1983 ) que geraram coeficientes de correlação genética variando de $-0,75$ a +0,54. Já SEBERN \& LAMBERT ( 1984 ) obtiveram coeficientes variando de $-0,23$ a $-0,58$, sendo altamente significativos estatisticamente. MAYOR \& SOTO ( 1985 ) obtiveram coeficientes 0,12 no verão e 0,02 no inverno, enquanto SURLAN-MOMIROVIC ( 1987 ) encontrou -0,52. XU \& WILCOX ( 1992 ) obtiveram $r=-0,21$ a $+0,18$. As esporádicas correlações positivas reportadas pela literatura permitem inferir que eventuais plantas com combinações favoráveis de produção e teor de proteína poderiam ser identificadas, porém fazse necessário frisar que, na maioria dos casos citados na literatura, a associação entre produção de grãos e teor de proteína é negativa. O oposto ocorre quando analisamos os caracteres teor de óleo e produção de grãos, cuja associação é normalmente positiva.

No entanto, verifica-se que a correlação fenotípica média foi de $-0,25$, calculada entre a ANAVA conjunta da produção dos ambientes 1, 3 e 4 versus a ANAVA individual do teor de proteína do ambiente 4. . Do mesmo modo que nas Tabelas 12 e 13, a 
covariância genética entre PG e TP é uma covariância limpa, livre dos efeitos da interação com o ambiente. O mesmo ocorre com a variância genética para PG. Assim, os valores das correlações genéticas ( $r_{G}$ PGXTP ) para os ambientes ANHEMBI, SERTÃOZINHO e ESALQ em relação à ESALQ $86 / 87$ são $-0,31 ;-0,38$ e $-0,58$, enquanto que as correlaçōes fenotípicas ficaram bem abaixo disso, com valores de $-0,18 ;-0,18$ e $-0,27$. MONTEVERDE ( 1984 ) obteve correlações fenotípicas da ordem de $+0,07,-0,05$ e $-0,25$, respectivamente para três populações.

Por fim, examinando-se novamente as correlações genéticas e fenotípicas médias das Tabelas 12, 13 e 14, percebe-se de pronto que na Tabela 12 a correlação genética média $(+0,33)$ é menor do que a correlação fenotípica média $(+0,38)$, o que não ocorre nas Tabelas 13 e 14, onde a relação de grandeza se inverte. Veja-se que no primeiro caso, os caracteres em discussão são TO e PG, os quais são correlacionados positivamente, genética e fenotipicamente. Ressalte-se também que um ambiente propicio à um bom desenvolvimento irá favorecer os dois caracteres. Logo, a correlação fenotípica haveria mesmo de se expressar em valores de ordem superior à correlação genética. No segundo caso entretanto, os caracteres envolvidos são TO e TP ( Tabela 13 ), e PG e TP ( Tabela 14 ), portanto, ambos negativamente correlacionados sob o aspecto genético. Porém, considerando-se que o ambiente estivesse agindo de maneira a favorecer ambos os caracteres envolvidos, tanto TO e TP, como PG e TP, obteria-se uma resultante de menor magnitude do que a correlação genética, uma vez que esta última constitui-se numa força atuando com sentidos opostos, isto é, afastando a magnitude dos dois caracteres, enquanto que o ambiente representa uma força que ,neste caso, atua no mesmo sentido, tendendo a aproximá-los. O resultado é uma correlação fenotípica menor do que a genotípica. 


\section{CONSIDERAÇÕES FINAIS}

Com base nos resultados deste trabalho e alicerçado nos dados da literatura, pode-se arrolar algumas sugestões no tocante ao melhoramento da soja para produção de grãos, teor de proteína e teor de óleo.

Considere-se inicialmente a grande variabilidade, tanto genotípica quanto fenotipica, existente nestes caracteres no gênero Glycine. Quanto à variabilidade fenotípica, o ambiente desempenha um papel fundamental no caráter produção de grãos, além de exercer efeitos significativos sobre teor de óleo e teor de proteína das sementes. Por exemplo, o teor de proteina, segundo a literatura apresentada neste trabalho, apresenta variações substanciais principalmente quanto à latitude e altitude ( HURBURGH et alii, 1990; WATANABE \& NAGASAWA, 1990 ). Estes dois fatores estão diretamente relacionados à disponibilidade de luz e à temperatura, e estes por sua vez, afetam a eficiência fisiológica da planta, originando com isto resultados diferenciados no tocante à produtividade de grãos e também quanto aos teores dos mais diversos constituintes.

Percebeu-se também no presente estudo, uma acentuada interação dos genótipos com os ambientes, o que dificulta o melhoramento para uma área geográfica não homogênea. Esta presença significativa da interação também foi observada em soja por MONTEVERDE ( 1984 ). Devido à presença da interação é importante que a seleção seja procedida com base na avaliação dos genótipos em vários ambientes ( locais e anos ), a fim de 
reduzir os efeitos da interação sobre a seleção. Ou seja, com base na avaliação em vários ambientes, evita-se a seleção de genótipos adaptados à ambientes específicos. Assim, selecionam-se genótipos mais generalistas, e consequentemente, obtem-se um progresso maior com a seleção.

Quanto ao tipo e magnitude da associação entre estes três caracteres e seus reflexos no melhoramento, pode-se assegurar que a maioria dos autores ( vide Apêndice 4 ) cita como sendo positiva a correlação entre produção de grãos e teor de óleo; negativa a correlação entre produção de grãos e teor de proteina; e negativa a correlação entre teor de óleo e teor de proteína das sementes. No entanto, verifica-se que a magnitude e o sentido das correlações podem variar muito de acordo com a população na qual os caracteres são mensurados (BURTON, 1987 ), o que pode ser verificado através do Apêndice 4.

Sem hesitar, pode-se afirmar que a produtividade de grãos é o caráter de maior interesse, visto que pode ser considerado o mais importante. Entretanto, diante das associaçōes descritas acima, facilmente percebe-se que seria muito difícil melhorar os três caracteres simultaneamente. Assim, sugere-se que sejam adotados programas distintos para o melhoramento destes caracteres, sendo que a produção de grãos sempre seria o caráter de maior ênfase. Adotaria-se pois um primeiro programa, no qual o objetivo seria incrementar a produção de grãos e elevar o teor de óleo dos mesmos. Um segundo programa visaria 0 aumento da produção de grãos e o aumento do teor proteico, sendo que tal programa teria plenas condições de alcançar êxito uma vez que a literatura nos assegura que nem em todas as populações a associação entre produção de grãos e teor de proteina é negativa, reportando inclusive várias proveitosas exceções, que permitiriam avanços importantes destes dois caracteres. Estes dois programas visariam o atendimento dos mercados especificos de óleo e farelo. 
Um terceiro programa poderia ser sugerido, no qual o objetivo seria o de melhorar a produção de grãos, mantendo, ou tentando manter num determinado platô, os teores de óleo e proteina. Isto poderia ser exeqüível através do desenvolvimento de um índice de seleção onde seriam considerados não somente os três caracteres, mas também a importância econômica relativa dos constituintes óleo e proteína. 


\section{CONCLUSÕES}

Os resultados obtidos neste trabalho permitiram apontar as seguintes conclusōes, considerando-se os quatro ambientes: 1: ANHEMBI 84/85; 2: SERTÃOZINHO 84/85; 3: ESALQ 84/85, e 4: ESALQ 86/87.

a. $O$ ambiente 2 destacou-se por apresentar a maior média para produção de grãos, porém apresentou uma alta interação com os demais ambientes e consequentemente uma baixa correlação para este caráter, indicando ser um ambiente atípico.

b. Os ambientes 1, 3 e 4 foram homogêneos quanto à produção de grãos, isto é, apresentaram uma alta correlação entre tratamentos e, consequentemente, uma baixa interação.

c. Todos os quatro ambientes exibiram diferenças estatisticas entre os tratamentos para os caracteres produção de grãos ( análise em quatro ambientes ), teor de óleo ( análise em três ambientes ) e teor de proteína ( análise em um ambiente ), com exceção da produção de grãos no ambiente 3.

d. O coeficiente de determinação genotípico ( $b$ ) foi relativamente alto para produção de grãos ( da ordem de $60 \%$ ) nos ambientes 1, 2 e 4 e nas análises combinadas destes, enquanto que para 0 ambiente 3 foi menor. 
e. Para o teor de proteína o coeficiente de determinação genotípico também foi relativamente alto ( $67 \%$ ), enquanto que para o teor de óleo foi ainda maior ( da ordem de $90 \%$ ) nos três ambientes, indicando ser este bem menos influenciado pelo ambiente.

f. Os caracteres "produção de grãos" e "teor de óleo" foram positivamente correlacionados $\left(\vec{r}_{G}=+0,33\right)$, enquanto que produção de grãos e teor de proteína $\left(\bar{r}_{G}=-0,47\right)$, e teor de óleo e teor de proteína $\left(\bar{r}_{G}=-0,31\right)$ foram negativamente correlacionados, indicando que a seleção baseada somente no teor de proteína irá acarretar reduções na produção de grãos e teor de óleo. Em todos os casos, a correlação fenotípica foi ligeiramente inferior em magnitude.

g. As estimativas de correlações genéticas e fenotípicas obtidas nas análises combinadas dos ambientes foram sempre superiores em magnitude às médias das estimativas individuais, e mais consistentes com a literatura, refletindo a importância da obtenção de estimativas de variâncias e covariâncias genéticas isentas de componentes da interação, bem como da redução da contribuição destes componentes nas estimativas de variâncias e covariâncias fenotípicas.

h. Embora a correlação entre o teor de proteína e a produção de grãos seja predominantemente negativa, a magnitude desta depende da população, havendo inclusive casos de correlação positiva, indicando que o melhoramento simultâneo para os dois caracteres é possível. 


\section{REFERÊNCIAS BIBLIOGRÁFICAS:}

ANUÁRIO ESTATÍSTICO DO BRASIL - 1991, Rio de Janeiro, 51 : 515, 1991.

ALMEIDA, F. R. F. Soja é o destaque da safra 1993/94. Conjuntura Econômica , Rio de Janeiro, 47 (11) :48-9, Nov. 1993.

BANZATO, D.A \& KRONKA, S.N. Análise de grupos de experimentos. In: BANZATO, D.A \& KRONKA, S. N. Experimentação agricola. Jaboticabal, FUNEP, 1989 . cap. 8, p.213-36.

BAYS, I.A. Heritability and association of several quantitative characters in segregating populations of soybeans ( Glycine max ( L.) Merrill ). Mississipi, 1975. 91p. (Ph.D Facult of Mississippi State University ).

BHATNAGAR, P.S.; TIWARI, S.P.; SINGH, C. Disrupting the negative association between oil and protein in soybean seeds through mutagenesis. Mutation Breeding Newsletter, Vienna, 39:7, 1992. Apud Plant Breeding Abstracts, Wallingford, 64 ( 2 ): 235, 1994. (Resumo). 
BONETTI, L.P. Distribuição da soja no mundo. In: MIYASAKA, S. \& MEDINA, J.C., ed. A soja no Brasil . Campinas, ITAL, 1981. p 1-6.

BURTON, J.W. Quantitative genetics: results relevant to soybean breeding. In: WILCOX, J.R., ed. Soybeans: improvement, production and uses . 2 ed. Madison, ASA, 1987. p. 211-47 ( Agronomy. A. ser. of Monographs, 16 ).

BRIM, C.A. Quantitative genetics and breeding. In: CALDWELL, B.E., ed. Soybeans: improvement, production, and uses. Madison, ASA, 1973. p 155-86 ( Agronomy. A Ser. of Monographs, 16 ).

BRIM, C.A. \& BURTON, J.W. Recurrent selection in soybeans. II. Selection for increased percent protein in seeds. Crop Science, Madison, 19 (4): 494-8, 1979.

BRUGNAGO NETO, S. Soja - produção mundial pressionará o mercado. Informe Conjuntural, Florianópolis, XII ( 530 ):5, Dezembro, 1994.

CHAUHAN, V.S. \& SINGH, B.B. Genetic analysis of protein and oil content in soybean. Indian Journal of Agricultural Sciences, $53: 8,634-37,1983$. Apud Plant Breeding Abstracts, Wallingford, 54 ( 4-5):405, 1984. (Resumo)

CHEN, H.H. Diallel analysis of the genetic regulation of protein and oil in soyabean. Scientia Agricultura Sinica , $20: 1,32-8,1987$. Apud Plant Breeding Abstracts, Wallingford, 57 (9):888, 1987 (Resumo). 
CHMELEVA, Z.V. \& KORSAKOV, N.I. Characterization of soyabean collection in respect of protein content and quality in the seeds. Trudy po Prikladnoi Botanike, Genetike i Seleltsii , Leningrad, 70 ( 2 ): 77-88, 1981. Apud Plant Breeding Abstracts, Wallingford, 54(12): 942, 1984 . (Resumo)

COLLINS, F.I. \& CARTTER, J.L. Variability in chemical composition of seed from diferent positions of the soybean plant. Agronomy Journal, Madison, 48 : 216-9, 1956.

ESCALANTE, E.E. \& WILCOX, J.R. Variation in seed protein among nodes of normal and high-protein soybean genotypes. Crop Science, Madison, 33 ( 6 ): 1164-6, 1993a.

ESCALANTE, E.E. \& WILCOX, J.R. Variation in seed protein among nodes of determinate and indeterminate soybean near-isolines. Crop Science, Madison, 33 (6): 1166-8, 1993b.

FALCONER, D.S. Introdução à genética quantitativa. Viçosa, UFV, 1987. 275p.

GERALDI, I.O. Estimação de parâmetros genéticos de caracteres do pendão em milho ( Zea mays L.) e perspectivas de melhoramento. Piracicaba, 1977. 103p. (Mestrado - Escola Superior de Agricultura "Luiz de Queiróz" / USP).

GHASSEMI, F.; YAZDI AMADI, B.; GHASEMI, F. Genetic investigation of eight quantitative characters in soyabean, Glycine max L. (Merr.) Iranian Journal of Agricultural Sciences, 17(3-4): 31-43, 1987. Apud Plant Breeding Abstracts, Wallingford, 58 ( 8 ): 773, 1988 ( Resumo).

GOMES, F.P. Curso de estatistica experimental. 13. ed. Piracicaba, Nobel, 1990. 468p. 
GORDON, I.L.; BITH, D.E.; BALAAM, L.N. Variance of heritability ratios estimated from phenotypic variance components. Biometrics, Raleigh, 28: 401-15, 1972.

GUODONG, Z. \& JINLING, W. Periodical variation and geographical distribution of protein and oil content of soybean varieties in Heilongjiang Province of China. Soybean Genetics Newsletter , Ames, $16: 41-2,1989$.

HADLEY, H.H. \& HYMOWITZ, T. Speciation and cytogenetics. In: CALDWELL, B.E., ed. Soybeans: improvement, production, and uses. Madison, ASA, 1973. p. 97-116 (Agronomy. A Ser. of Monographs, 16).

HAN, F.; LING, Y.L.; CHEN, S. Electrophoresis analysis of seed protein of five wild perennial species and two cultivars in Glycine. Oil Crops of China, 4: 17-21, 1991. Apud Plant Genetic Resources Abstracts, Wallingford, 3 ( 1 ): 64, 1994 .(Resumo )

HARTWIG, E.E. \& KILEN, T.C. Yield and composition of soybean seed from parents with different protein, similar yield. Crop Science, Madison, 31 (2): 290-2, 1991.

HOWELL, R.W. \& CALDWELL, B.E. Genetic and other biological characteristics. In: SMITH, A.K.; CIRCLE, S.J. Soybeans: chemistry and technology. Westport, Avi Publishing Company INC., 1978. 470p.

HUANG, J.C. \& TONG, C.L. Analyses on the variation of protein and fat and their correlation in wild soyabean in Fujian. Fujian Agricultural Science and Technology, 1 : 7-8, 1990. Apud Plant Breeding Abstracts, Wallingford, 61 (1): 137, 1991.(Resumo ). 
HURBURGH Jr., C.R.; BRUMM, T.J.; GUINN, J.M.; HARTWIG, R.A. Protein and oil patterns in U.S. and world soybean markets. Journal of the American Oil Chemist's Society, Champaign, 67 (12): 887-1044, 1990.

HUSKEY, L.L.; SNYDER, H.E.; GBUR, E.E. Analyses of single soybean seeds for oil and protein. Journal of the American Oil Chemist's Society, Champaign, 67: 686-88, 1990.

HYMOWITZ, T. On the domestication of soybean. Economic Botany, New York, 24 ( 4 ): 408-21, 1970.

HYMOWITZ, T. \& SINGH, R.J. Taxonomy and speciation. In: WILCOX, J.R., ed. Soybeans: improvement, production, and uses. 2.ed. Madison, ASA, 1987. p.23-48 ( Agronomy. A Ser. of Monographs, 16 ).

ISHIGE, T. Biometrical analysis and estimation of the number of genes for seed protein content of soybean, Glycine max (L. ) Merrill. Japan Agricultural Research Quarterly, Yatabe, 17( 4 ): 230-5, 1984.

JOHNSON, H.W.; ROBINSON, H.F.; COMSTOCK, R.E. Genotypic and phenotypic correlations in soybeans and their implications in selection. Agronomy Journal , Madison, $47(10)$ : 477-83, 1955.

JUNZHENG, Z. \& ZHIHONG, H. Genetic improvement and eco-geographical distribution of composition of soybean varieties released in Heilongjiang Province of China. Soybean Genetics Newsletter, Ames, $18:$ 90-5, 1991. 
KAMIKOGA, M.K. Herança do acamamento e associações com outros caracteres em soja ( Glycine $\max$ ( L.) Merrill ). Piracicaba, 1989. 129p. (Mestrado - Escola Superior de Agricultura "Luiz de Queiroz"/USP ).

KENWORTHY, W.J. Potential genetic contributions of wild relatives to soybean improvement. In: WORLD SOYBEAN RESEARCH CONFERENCE, 4., Buenos Aires, 1989. Proceedings . Buenos Aires, Orientación Gráfica, 1989. p. 883-8

KILEN, T.C. Brachytic stem and narrow leaflet effects on soybean seed composition and yield. Crop Science, Madison, 30 : 1006-8, 1990.

KIM, S.D.; KIM, Y.H.; HONG, E.H.; LEE, H.S. Chemical components of black soybean seeds collected in Korea. Korean Journal of Crop Science, 38 ( 1 ):1-7, 1993. (Resumo).

KOCHEGURA, A.V. Differences in seed quality within the plant. Selektsiya i Semenovodstvo, Krasnodar, 9: 24-5, 1982. Apud Soyabean Abstracts, 8 ( 1 ): 241, 1985. (Resumo).

LAM SANCHEZ, A.; DURIGAN, J.F.; ASSIS, G.M. Respostas de genótipos de soja ( Glycine max (L.) Merrill ) ao retardamento de colheita quanto aos conteúdos de proteína e óleo da semente. Cientifica, São Paulo, 17 ( 1 ): 121-5, 1989.

MAYOR, Z.F. \& BAYÓN, G. Correlaciones y coeficentes de sendero en tres variedades de soya ( Glycine max ), en época de primavera. Ciências de La Agricultura , Habana, 24 : 129-30, 1985. 
MAYOR, Z.F. \& SOTO, J.A. Influencia de diferentes factores en el contenido de proteinas del grano de soya (Glycine max ). Ciencias de La Agricultura , La Habana, 25 : 51-7, 1985.

MAYOR, Z.F. \& SOTO, J.A. Correlaciones e coeficientes de sendero para el porcentaje de aceite en variedades de soya. Ciências de La Agricultura, La Habana, 26 :137-8, 1986.

MAYOR, Z.F.; SOTO, J.A.; PLASENCIA, A. Correlaciones fenotípicas, genéticas y ambientales en variedades de soya. Ciências de La Agricultura, La -Habana, 34-35: 69-76, 1988.

McKENDRY, A.L.; McVETTY, P.B.E.; VOLDENG, H.D. Inheritance of seed protein and seed oil content in early maturing soybean. Canadian Journal of Genetics and Cytology , Ottawa, 27 ( 5 ): 603-7, 1985.

MIYASAKA, S. Generalidades. In: FUNDAÇÃO CARGILL. A soja no Brasil central . 2. ed. Campinas, Fundação Cargill, 1982. p. 3-19.

MOHAMED, A.I. \& RANGAPPA, M. Screening soybean ( grain and vegetable ) genotypes for nutrients and anti-nutritional factors. Plant Foods for Human Nutrition, Dordrecht, 42 (1): 87-96, 1992.

MONTEVERDE, E. Correlaciones fenotipicas y genotipicas entre rendimiento, proteina, aceite y otras caracteristicas en soya ( Glycine max ). Revista de la Facultad de Agronomia , Macaray, 13 ( 1/4): 183-214, 1984. 
OPENSHAW, S.J. \& HADLEY, H.H. Selection to modify sugar content of soybean seeds. Crop Science, Madison, 21 ( 6 ): 805-8, 1981.

OPENSHAW, S.J. \& HADLEY, H.H. Selection indexes to modify protein concentration of soybean seeds. Crop Science, Madison, 24 ( 1 ): 1-4, 1984.

PIMENTEL, A.M. Cruzamentos dialélicos em soja com ênfase em teor de proteína e produção de grãos. Piracicaba, 1991. 150p. ( Mestrado - Escola Superior de Agricultura "Luiz de Queiróz" ( USP ).

PROBST, A.H. \& JUDD, R.W. Origin, U.S. history and development, and world distribution. In: CALDWELL, B.E., ed. Soybeans: improvement, production, and uses. Madison, ASA, 1973. p. 1-12 (Agronomy. A Ser. of Monographs, 16 ).

PROKUDIN, G.V. Study of the chemical composition of the seeds in soyabean mutants and their initial forms. Geneticheskle Osnovy IntroduktsII I SelektsII Rastenll , 85-8, 1987. Apud Plant Breeding Abstracts, Wallingford, 59 ( 5 ): 476, 1989. (Resumo ).

PULCINELLI, C.E. Herança do teor de proteína em soja. Piracicaba, 1992. 67 p. ( Mestrado - Escola Superior de Agricultura " Luiz de Queiroz " / USP ).

RANA, N.D.; KALIA, R.K.; GUPTA, V.P. Correlation among seed yield, seed quality and nutritional traits in soybean. Soybean Genetics Newsletter, Ames, $9: 81-5,1982$. 
REDDY, P.N.; REDDY, K.N.; RAO, S.P. Effect of size on qualitative and quantitative traits in soybean ( Glycine max (L.) Merrill). Seed Science and Technology , Wageningen, 17 (2): 289-95, 1989.

SEBERN, N.A. \& LAMBERT, J.W. Effect of stratification for percent protein in two soybean populations. Crop Science, Madison, 24 ( 2 ): 225-8, 1984.

SHANNON, J.G.; WILCOX, J.R.; PROBST, A.H. Estimated gains from selection for protein and yield in the F4 generation of six soybean populations. Crop Science, Madison, 12 (6): 824-6, 1972.

SHARMA, S.K.; RANA, N.D.; MEHTA, H. Genetic variability, interrelationship and path coefficient analysis in a collection of small seeded soybean. Egyptian Journal of Genetics and Citology, Alexandria, 15 ( 2 ): 273-83, 1986.

SHORTER, R,; BYTH, D.E.; MUNGOMERY, V.E. Estimates of selection parameters associated with protein and oil content of soybean seeds ( Glycine max (L.) Merr. ) Australian Journal of Agricultural Research, East Melbourne, 28 ( 2): 211-22, 1977.

SIMPSON, A.M. \& WILCOX, J.R. Genetic and phenotypic associations of agronomic characteristics in four high protein soybean populations. Crop Science, Madison, 23 (6): 1077-81, 1983.

SMITH, K.J. \& HUYSER, W. World distribution and significance of soybean. In: WILCOX, J.R.. ed. Soybeans: improvement, production, and uses. 2.ed. Madison, ASA, 1987. p. 1-22 (Agronomy. A Ser. of Monographs, 16 ). 
SOLDINI, D.O. Interação genótipos X locais e correlações entre caracteres com ênfase na produtividade de óleo em soja. Piracicaba, 1993. 136 p. (Mestrado - Escola Superior de Agricultura " Luiz de Queiroz "/ USP ).

SONG, Q.J.; GAI, J.Y.; MA, R.H. Studies on the combining ability of protein content and fatty content in soyabean. Acta Agronomica Sinica, Beijing, 17 ( 2 ): 128-134, 1991. Apud Plant Breeding Abstracts, Wallingford, 63 ( 3 ): 339, 1993. (Resumo)

STEEL, R.G.D. \& TORRIE, J.H. Principles and procedures of statistics. New York, McGraw Hill Book Company, 1960. 481p.

SURLAN-MOMIROVIC, G. Genetic and phenotypic correlations among morphological and biochemical traits in different varieties of soyabean Glycine max L. Merrill. Poljoprivedna Znanstvena Smotra, Zagreb, 76/77: 5-17, 1987a. Apud Plant Breeding Abstracts, Wallingford, 58 ( 6 ): 589, 1988 (Resumo ).

SURLAN-MOMIROVIC, G. Heritability and genotypic and phenotypic correlations between biochemical characters of different soyabean varieties. Arhiv za Poljoprivredne Nauke ( Journal for Scientific Agricultural Research ), Beograd, 48 ( 4 ): 413-21, 1987b. Apud Plant Breeding Abstracts, Wallingford, 59 ( 7 ): 691, 1989. (Resumo ).

TAKAGI, Y.; KISHIKAWA, H.; EGASHIRA, M. Variability in oil content, protein content ald oleic acid content of seed from different portions of the soyabean plant. Bulletin Fac. Agr. Saga University, Saga, 53:47-54, 1982. Apud Soybean Abstracts, 6 ( 8 ): 190, 1993. ( Resu- mo) 
VASHCHENKO, A.P.; MUDRIK, N.V.; KHOKHLOVA, N.I. Interrelation of the protein and oil content traits in seeds of soyabeans in the Primor'e. Nauchono Tekhniches kii Byulleten Vsesoyuznogo Ordena Lenina i Ordena Druzhby Norodov Nauchno Issledovatel'skogo Instituta Rastenievodstva Imen N.I. Vavilova , Leningrad, 194: 1315, 1989. Apud Plant Breeding Abstracts, Wallingford, 61( 4 ): 493, 1991. (Resumo)

VELLO, N.A \& VENCOVSKY, R. Variâncias associadas às estimativas de variâncias genéticas e coeficientes de herdabilidade. Relatório Científico do Departamento de Genética. Piracicaba, 8: 238-48, 1974.

VENCOVSKY, R. \& BARRIGA, P. Genética biométrica no fitomelhoramento. Ribeirão Preto, Revista Brasileira de Genética, 1992. 496p.

WATANABE, I. \& NAGASAWA, T. Appearance and chemical composition of soybean seeds in germplasm collection of Japan. I. Frequency distribution of grain size, seed coat colour, hilum colour and content of chemical components, with special reference to collection site. Japanese Journal of Crop Science , Kariwano, 59 ( 4 ): 649-60, 1990. Apud Plant Breeding Abstracts, Wallingford, 61 ( 6 ): 736, $1991 . \quad$ (Res umo)

WENBIN, L. \& JINLING, W. Comparison of inheritance of several agronomic characters between Glycine $\max \times$ Glycine soja, G. $\max \times$ G. gracilis, and G. $\max \times$ G. max. Soybean Genetics Newsletter, Ames, $13: 59-61,1986$.

WENBIN, L. \& JINLING, W. Analysis of diallel crosses between the lines of interspecific hybrids and cultivars in soybean. I. Overcoming small seed trait of wild and semi-wild soybeans. Soybean Genetics Newsletter , Ames, $15: 36-40,1988$. 
WEHRMANN, V.K.; FEHR, W.R.; CIANZIO, S.R.; CAVINS, J.F. Transfer of high seed protein to high-yielding soybean cultivars. Crop Science, Madison, 25 ( 5 ): 927-31, 1987.

WILCOX, J.R. Breeding for seed protein content in soybeans. Journal of the American Oil Chemist's Society, Champaign, 63 ( 4 ): 457, 1986.

WILCOX, J.R. Soybean protein and oil quality. In: CONFERÊNCIA MUNDIAL DE INVESTIGATION EN SOJA, 4., Buenos Aires, 1989. Proceedings. Buenos Aires, PASCALE, A.J. , 1989. p. 29-39.

XU, H. \& WILCOX, J.R. Recurrent selection for maturity and percent seed protein in Glycine max based on $S \varnothing$ plant evaluations. Euphytica, Wageningen, $62: 51-7,1992$.

YU, Y.D. \& GAI, J.Y. Study on genetic variability of protein and oil content in soyabean. Journal of Shandong Agriculture University, 22 ( 3 ): 201-6, 1991 . Apud Plant Breeding Abstracts, Wallingford, 63 ( 3 ): 339, 1993 . (Re sumo) 
TABELAS 
Tabela 6 - Médias de duas repetiçőes de 30 genótipos avaliados em quatro ambientes para os caracteres Produçăo de Grăos ( PG; g/parcela), Teor de Óleo ( TO; \% ) e Teor de Proteina ( TP; \% ), produção de Proteína (PP; Kg/ha).

\begin{tabular}{|c|c|c|c|c|c|c|c|c|c|}
\hline \multirow{3}{*}{$\begin{array}{l}\text { Genótipos } \\
\text { Ax } 5355\end{array}$} & \multicolumn{2}{|c|}{ Ambiente 1} & \multicolumn{2}{|c|}{ Ambiente 2} & \multicolumn{2}{|c|}{ Ambiente 3} & \multicolumn{3}{|c|}{ Ambiente 4} \\
\hline & $P G$ & TO & PG & TO & $P G$ & TO & PG & TP & PP \\
\hline & 584 & 21,40 & 1220 & 19,75 & 1106 & $21, \infty$ & 791 & 44,10 & 348,83 \\
\hline CNS & 585 & 20,40 & 1289 & 20,40 & 677 & 22,80 & 489 & 39,50 & 193,16 \\
\hline SOC 81105 & 1085 & 22,75 & 1418 & 21,45 & 1135 & 21,35 & 784 & 36,70 & 287,73 \\
\hline BR-1 Fosca & 882 & 22,05 & 1118 & 23,20 & 979 & 23,90 & 581 & 36,50 & 212,07 \\
\hline BR-5 & 847 & 23,70 & 1191 & 22,70 & 1059 & 24,20 & 625 & 41,10 & 256,87 \\
\hline PI 322-694 & 437 & 19,50 & 974 & 19,00 & 1169 & 21,40 & 646 & 40,10 & 259,05 \\
\hline FT-2 & 825 & 22,65 & 1438 & 21,40 & 1461 & 22,85 & 807 & 35,00 & 282,45 \\
\hline GO 818106 & 698 & 22,00 & 1138 & 21,00 & 1070 & 21,80 & 907 & 36,80 & 333,78 \\
\hline La49-10-215 & 684 & 19,50 & 1299 & $19, \infty 0$ & 1127 & 21,95 & 681 & 43,05 & 293,17 \\
\hline Biloxi & 860 & 20,70 & 909 & 19,60 & 1108 & 21,90 & 811 & 46,20 & 374,68 \\
\hline SOC 81228 & 797 & 23,56 & 1371 & 20,80 & 1062 & 23,60 & 513 & 37,65 & 193,14 \\
\hline BR 80-6935 & 885 & 22,90 & 1182 & 20,25 & 1024 & 22,55 & 968 & 37,45 & 362,52 \\
\hline IAS-3 Delta & 1019 & 21,55 & 1367 & 20,45 & 1069 & 22,95 & 565 & 39,00 & 220,35 \\
\hline Batavian Yellow & 607 & 20,95 & 1144 & 19,75 & 1155 & 20,60 & 929 & 36,90 & 342,80 \\
\hline FT $79-3408$ & 913 & 23,50 & 1300 & 22,45 & 1451 & 23,80 & 907 & 35,50 & 321,98 \\
\hline Mineira & 1050 & 22,75 & 1171 & 20,60 & 1243 & 24,75 & 1053 & 40,40 & 425,41 \\
\hline Dourados & 961 & 22,20 & 1178 & 19,70 & 1290 & 21,80 & 886 & 40,05 & 354,84 \\
\hline BR-80-14887 & 802 & 18,40 & 1330 & 17,35 & 939 & 19,05 & 508 & 39,40 & 200,15 \\
\hline Sta Rosa Verde & 912 & 23,45 & 1142 & 22,40 & 1165 & 23,65 & 566 & 40,15 & 227,25 \\
\hline Gaúcha & 821 & 19,85 & 1241 & 20,05 & 1028 & 21,35 & 561 & 45,40 & 254,69 \\
\hline Hampton & 696 & 23,60 & 1278 & 23,05 & 1065 & 25,00 & 838 & 42,80 & 358,66 \\
\hline Hardee & 603 & 23,50 & 1282 & 23,60 & 1322 & 24,55 & 524 & 41,15 & 215,63 \\
\hline GO $81-11081$ & 868 & $21, \infty$ & 952 & 21,35 & 1363 & 23,30 & 813 & 36,85 & 299,60 \\
\hline FT 10 (Princesa) & 730 & 20,80 & 1340 & 21,60 & 1408 & 23,50 & 548 & 42,70 & 234,00 \\
\hline IAC-2 & 1028 & 23,40 & 1180 & 21,50 & 1079 & 25,50 & 789 & $40, \infty 0$ & 320,33 \\
\hline $\mid A C-3$ & 867 & 22,65 & 1082 & 21,55 & 1469 & 23,75 & 677 & 37,10 & 251,17 \\
\hline Nova Sta Rosa & 944 & 23,50 & 1201 & 21,40 & 1336 & 23,95 & 677 & 37,20 & 251,84 \\
\hline Såo Luiz & 940 & 21,90 & 1269 & 21,45 & 1470 & 24,15 & 863 & 36,15 & 311,97 \\
\hline Yelnanda & 871 & 20,90 & 1271 & 20,80 & 1226 & 23,40 & 590 & 41,45 & 244,55 \\
\hline IAC-11 & 1192 & 21,95 & 1060 & 21,85 & 1280 & 23,50 & 1382 & 41,65 & 575,60 \\
\hline Davis & 685 & 22,27 & 1324 & 21,84 & 965 & 23,51 & $\ldots \ldots \ldots$ & $\ldots \ldots \ldots$ & $\ldots \ldots \ldots$ \\
\hline Bossier & 756 & 23,13 & 1357 & 22,50 & 1436 & 23,94 & 1115 & 41,55 & $\ldots \ldots .$. \\
\hline IAC 12 & 1078 & 23,11 & 1266 & 22,44 & 1314 & 22,70 & 1198 & 42,40 & $\ldots \ldots \ldots$ \\
\hline IAC 10 & 1065 & 22,50 & 1137 & 22,62 & 1313 & 24,11 & ......... & .......... & ........... \\
\hline IAC 11 & 1043 & 22,88 & 1328 & 22,27 & 1285 & 24,40 & $\ldots \ldots \ldots$ & ......... & …..... \\
\hline$S-573$ & ........ & ......... & $\ldots \ldots .$. & ......... & ......... & ......... & 679 & 43,20 & 293,33 \\
\hline IAC Foscarin 31 & .......... & .......... & ........... & $\ldots \ldots .$. & .......... & .......... & 758 & 39,25 & 297,51 \\
\hline S-574 & ......... & $\ldots \ldots .$. & $\ldots \ldots \ldots$ & ......... & ......... & ......... & 457 & $46, \infty 5$ & 213,19 \\
\hline IAC 8 & 892 & 22,35 & 1267 & 20,90 & 1518 & 23,60 & 1437 & 45,85 & 658,86 \\
\hline Média Geral & 833 & 21,92 & 1211 & 20,98 & 1178 & 22,93 & 743 & 39,62 & 294,23 \\
\hline \multicolumn{10}{|l|}{ Onde: } \\
\hline \multicolumn{3}{|c|}{$\begin{array}{l}\text { Ambiente } 1=\text { Anhembi } 1984 / 85^{\star \star \star} \\
\text { Ambiente } 2=\text { Sertăozinho } 1984 / 85^{\star \star \star \star}\end{array}$} & \multicolumn{4}{|c|}{$\begin{array}{l}\text { Ambiente } 3=\text { ESALQ 1984/85 } \\
\text { Ambiente } 4=\text { ESALQ 1986/87 }\end{array}$} & \multicolumn{3}{|c|}{$\begin{array}{l}\text { Parcela }=4,8 \mathrm{~m}^{2} \text { (área útil) } \\
\text { *** Dados de SOLDINI ( } 1993 \text { ) }\end{array}$} \\
\hline
\end{tabular}


Tabela 7 - Análises de variância individuais com quadrados médios, médias e coeficientes de variação nos quatro ambientes para o caráter Produção de Grãos (PG ).

\begin{tabular}{|c|c|c|c|c|c|}
\hline \multirow[t]{2}{*}{ FV } & \multicolumn{2}{|c|}{ GL } & \multicolumn{3}{|c|}{ QM para Produção de Grãos (g/parcela ) ${ }^{2}$} \\
\hline & & $\begin{array}{c}\text { PG } \\
\text { Ambiente } 1\end{array}$ & $\begin{array}{c}\text { PG } \\
\text { Ambiente } 2\end{array}$ & $\begin{array}{c}\text { PG } \\
\text { Ambiente } 3\end{array}$ & $\begin{array}{c}\text { PG } \\
\text { Ambiente } 4\end{array}$ \\
\hline $\begin{array}{l}\text { Repetiçöes } \\
\text { Tratamentos } \\
\text { Erro exp. }\end{array}$ & $\begin{array}{r}1 \\
29 \\
29\end{array}$ & $\begin{array}{l}3896 \\
57332 \text { ** } \\
21456\end{array}$ & $\begin{array}{c}264 \\
34238 \\
13359\end{array}$ & $\begin{array}{l}170440 \\
66886 \text { ns } \\
49632\end{array}$ & $\begin{array}{c}454864 \\
79126 \\
19750\end{array}$ \\
\hline $\begin{array}{l}\text { Média g/parc } \\
\text { CV (\%) } \\
\text { D.M.S. }\end{array}$ & & $\begin{array}{r}833 \\
17,58 \\
606\end{array}$ & $\begin{array}{r}1211 \\
9,54 \\
478\end{array}$ & $\begin{array}{r}1178 \\
18,91 \\
922\end{array}$ & $\begin{array}{r}743 \\
18,92 \\
582\end{array}$ \\
\hline
\end{tabular}

DMS = Diferença Mínima Significativa ( Teste Tukey à 5\% )

** $=$ Significativo a $1 \%$ de probabilidade

Onde:

Ambiente $1=$ Anhembi 1984/85

Ambiente 2 = Sertãozinho 1984/85

Ambiente 3 = ESALQ 1984/85

Ambiente 4 = ESALQ 1986/87

Parcela $=4,8 \mathrm{~m}^{2}$ (área útil ) 
Tabela 8 - Análises de variância individuais com quadrados médios, médias e coeficientes de variação nos quatro ambientes para o caráter Teor de Óleo ( TO ) e Proteína ( TP ).

\begin{tabular}{|c|c|c|c|c|c|}
\hline \multirow[t]{3}{*}{ FV } & \multirow[t]{3}{*}{ GL } & \multicolumn{4}{|c|}{ QM para Teor de Óleo e Proteína $(\%)^{2}$} \\
\hline & & TO & TO & TO & TP \\
\hline & & Ambiente 1 & Ambiente 2 & Ambiente 3 & Ambiente 4 \\
\hline $\begin{array}{l}\text { Repetiçöes } \\
\text { Tratamentos } \\
\text { Erro exp }\end{array}$ & $\begin{array}{r}1 \\
29 \\
29\end{array}$ & $\begin{array}{l}2,20 \\
4,13 \\
0,29\end{array}$ & $\begin{array}{l}0,37 \\
3,84 \text { ** } \\
0,62\end{array}$ & $\begin{array}{l}1,57 \\
4,25 * * \\
0,64\end{array}$ & $\begin{array}{c}0,24 \\
17,61 \\
5,72\end{array}$ \\
\hline $\begin{array}{l}\text { Média (\%) } \\
\text { CV (\%) } \\
\text { DMS }\end{array}$ & & $\begin{array}{r}21,92 \\
2,45 \\
2,22\end{array}$ & $\begin{array}{r}20,98 \\
3,74 \\
3,25\end{array}$ & $\begin{array}{r}22,93 \\
3,49 \\
3,31\end{array}$ & $\begin{array}{r}39,62 \\
6,04 \\
9,89\end{array}$ \\
\hline
\end{tabular}

DMS = Diferença Mínima Significativa ( Teste Tukey à 5\% )

** $=$ Significativo a $1 \%$ de probabilidade

Onde:

Ambiente 1 = Anhembi 1984/85

Ambiente 2 = Sertãozinho $1984 / 85$

Ambiente 3 = ESALQ 1984/85

Ambiente $4=$ ESALQ 1986/87

Parcela $=4,8 \mathrm{~m}^{2}$ (área útil) 
Tabela 9 - Graus de liberdade e quadrados médios das ANAVAS individuais e conjuntas para os três caracteres nos quatro ambientes.

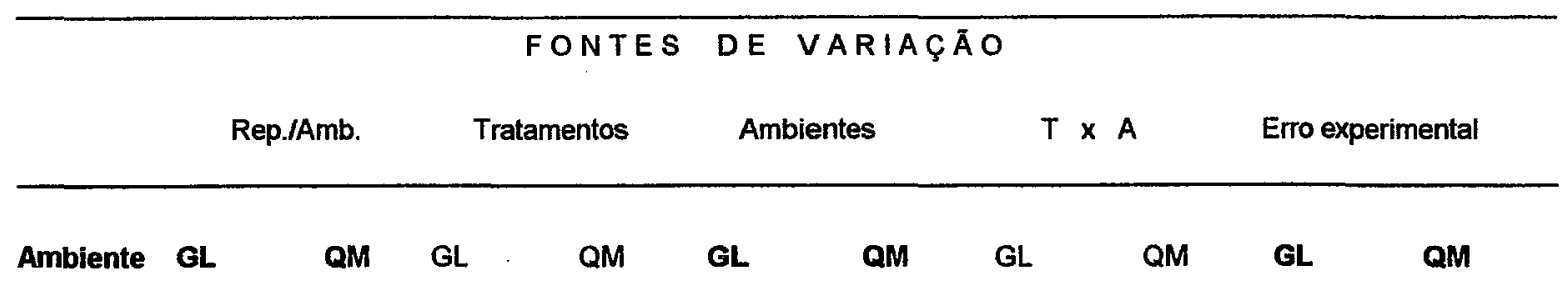

PRODUÇÃO DE GRĀOS

\begin{tabular}{|c|c|c|c|c|c|c|c|c|c|c|}
\hline 1 & 1 & 3896 ns & 29 & $57332^{* *}$ & - & --- & - & -...- & 29 & 21456 \\
\hline 2 & 1 & $264 \mathrm{~ns}$ & 29 & 34238 ** & - & - & - & - & 29 & 13350 \\
\hline 3 & 1 & $170440 \mathrm{~ns}$ & 29 & $66886 \mathrm{~ns}$ & - & - & -- & - & 29 & 49632 \\
\hline 4 & 1 & $454864^{* *}$ & 29 & $79126^{\star *}$ & - & - & - & - & 29 & 19750 \\
\hline $1 \times 2$ & 2 & $2081 \mathrm{~ns}$ & 29 & 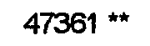 & 1 & 4288032 ** & 29 & $44209^{* *}$ & 58 & 17408 \\
\hline $1 \times 3$ & 2 & 87167 ns & 29 & $77559 \mathrm{~ns}$ & 1 & 3565232 * & 29 & 46659 ns & 58 & 35544 \\
\hline $1 \times 4$ & 2 & $229380^{* *}$ & 29 & 96736 ** & 1 & 245526 ns & 29 & 39722 * & 58 & 20603 \\
\hline $2 \times 3$ & 2 & 85352 ns & 29 & $48655 \mathrm{~ns}$ & 1 & $33333 \mathrm{~ns}$ & 29 & $52469^{*}$ & 58 & 31495 \\
\hline $2 \times 4$ & 2 & $227564^{\star *}$ & 29 & 39811 ** & 1 & 6585704 * & 29 & $73553^{\text {** }}$ & 58 & 16554 \\
\hline $3 \times 4$ & 2 & $312652^{* *}$ & 29 & $95514^{*}$ & 1 & 5681971 * & 29 & $50498 \mathrm{~ns}$ & 58 & 34691 \\
\hline $1 \times 3 \times 4$ & 3 & $200734^{\star \star}$ & 29 & $112091 * *$ & 2 & $3164243^{*}$ & 58 & 45626 * & 87 & 30279 \\
\hline
\end{tabular}

TEOR DE ÓLEO

$\begin{array}{lllllllllll}1 & 1 & 2.20^{*} & 29 & 4.13^{\star *} & - & - & - & - & 29 & 0.29 \\ 2 & 1 & 0.37 \mathrm{~ns} & 29 & 3.84^{\star *} & -- & - & - & - & 29 & 0.62 \\ 3 & 1 & 1.57 \mathrm{~ns} & 29 & 4.25^{* *} & - & - & - & - & 29 & 0.64 \\ 1 \times 2 & 2 & 1.28 \mathrm{~ns} & 29 & 7.06^{\star *} & 1 & 26.32^{*} & 29 & 0.91^{*} & 58 & 0.45 \\ 1 \times 3 & 2 & 1.88^{*} & 29 & 7.21^{* *} & 1 & 30.60^{*} & 29 & 1.17^{* *} & 58 & 0.46 \\ 2 \times 3 & 2 & 0.97 \mathrm{~ns} & 29 & 7.23^{* *} & 1 & 113.69^{* *} & 29 & 0.86 \mathrm{~ns} & 58 & 0.63\end{array}$

TEOR DE PROTEINA

$\begin{array}{llllllllllll}4 & 1 & 0.24 \mathrm{~ns} & 29 & 17.61^{* *} & - & & - & - & - & & \end{array}$

${ }^{*}=$ Significativo a $5 \% ;{ }^{* *}=$ Significativo a $1 \%$; ns = năo significativo

Onde:

Ambiente $1=$ Anhembi $1984 / 85$

Ambiente 2 = Sertăozinho $1984 / 85$

Ambiente $3=E S A L Q 1984 / 85$

Ambiente 4 = ESALQ 1986/87

Parcela $=4,8 \mathrm{~m}^{2}$ (área útil) 
Tabela 10 - Variância Genética $\left(V_{t}\right)$ e Ambiental $\left(V_{e}\right)$, respectivos Desvios e Coeficientes de Variação.

\begin{tabular}{|c|c|c|c|c|c|c|}
\hline Ambiente & $v_{t}$ & $\begin{array}{c}\text { Desvio } \\
\mathrm{V}_{\mathrm{t}}\end{array}$ & CV \% & $\mathrm{Ve}$ & $\begin{array}{c}\text { Desvio } \\
\text { Ve }\end{array}$ & CV \% \\
\hline \multicolumn{7}{|c|}{ PRODUÇÃO DE GRÃOS } \\
\hline 1 & 17937,7 & 7774,4 & 44,3 & 21456,4 & 5449,9 & 25,4 \\
\hline 2 & 10439,7 & 4667,5 & 44,7 & 13358,8 & 3393,1 & 25,4 \\
\hline 3 & 8627,0 & 10577,7 & 122,6 & 49631,9 & 12606,5 & 25,4 \\
\hline 4 & 29688,1 & 10357,4 & 34,9 & 19750,1 & 5016,5 & 25,4 \\
\hline $1 \times 2$ & 7488,3 & 4114,1 & 54,9 & 17407,6 & 3178,2 & 18,3 \\
\hline $1 \times 3$ & 7725,1 & 5747,5 & 74,4 & 35544,2 & 6489,5 & 18,3 \\
\hline $1 \times 4$ & 14253,4 & 6640,4 & 46,6 & 20603,3 & 3761,6 & 18,3 \\
\hline $2 \times 3$ & 4289,8 & 4543,8 & 105,9 & 31495,4 & 5750,3 & 18,3 \\
\hline $2 \times 4$ & 5814,2 & 5310,9 & 91,3 & 16554,5 & 3022,4 & 18,3 \\
\hline $3 \times 4$ & 11253,8 & 6860,6 & 60,9 & 34691,1 & 6333,7 & 18,3 \\
\hline $1 \times 3 \times 4$ & 11077,5 & 4944,1 & 44,6 & 30279,5 & 4539,1 & 14,9 \\
\hline \multicolumn{7}{|c|}{ TEOR DE ÓLEO } \\
\hline 1 & 1,92 & 0,53 & 27,6 & 0,29 & 0,07 & 24,4 \\
\hline 2 & 1,61 & 0,49 & 30,4 & 0,62 & 0,16 & 26,0 \\
\hline 3 & 1,80 & 0,55 & 30,5 & 0,64 & 0,16 & 24,6 \\
\hline $1 \times 2$ & 1,65 & 0,45 & 27,2 & 0,45 & 0,08 & 17,7 \\
\hline $1 \times 3$ & 1,51 & 0,46 & 30,4 & 0,46 & 0,08 & 17,2 \\
\hline $2 \times 3$ & 1,65 & 0,46 & 27,9 & 0,63 & 0,11 & 17,5 \\
\hline \multicolumn{7}{|c|}{ TEOR DE PROTEÍNA } \\
\hline 4 & 5,94 & 2,35 & 39,5 & 5,72 & 1,45 & 25,3 \\
\hline
\end{tabular}

Onde:

Ambiente 1 = Anhembi $1984 / 85$

Ambiente 2 = Sertãozinho 1984/85

Ambiente 3 = ESALQ 1984/85

Ambiente $4=$ ESALQ 1986/87

Parcela $=4,8 \mathrm{~m}^{2}$ (área útil) 
Tabela 11 - Coeficiente de determinação genotípico ( b ), e seu respectivo desvio, em valor absoluto e em porcentagem ( CV).

\begin{tabular}{cccc}
\hline Ambiente & Desvio & Desvio b \\
& $b$ & $b$ & $(\%)$
\end{tabular}

PRODUÇÃO DE GRÃOS

$\begin{array}{lrrr}1 & 0,63 & 0,13 & (21,5) \\ 2 & 0,61 & 0,14 & (23,0) \\ 3 & 0,26 & 0,27 & (103,3) \\ 4 & 0,75 & 0,09 & (11,9) \\ 1 \times 2 & 0,63 & 0,13 & (20,9) \\ 1 \times 3 & 0,39 & 0,22 & (54,2) \\ 1 \times 4 & 0,15 & (25,0) \\ 2 \times 3 & 0,59 & 0,23 & (65,9) \\ 2 \times 4 & 0,35 & 0,15 & (25,6) \\ 3 \times 4 & 0,58 & 0,19 & (40,3) \\ 134 & 0,47 & 0,13 & (21,5)\end{array}$

TEOR DE ÓLEO

$\begin{array}{ll}1 & 0,93 \\ 2 & 0,84 \\ 3 & 0,85 \\ 1 \times 2 & 0,94 \\ 1 \times 3 & 0,84 \\ 2 \times 3 & 0,91\end{array}$

0,02

0,06

0,05

0,02

0,06

0,03

TEOR DE PROTEINA

4

0,67

0,12

$(17,3)$

Onde:

Ambiente $1=$ Anhembi $1984 / 85$

Ambiente 2 = Sertãozinho 1984/85

Ambiente 3 = ESALQ 1984/85

Ambiente $4=$ ESALQ 1986/87

Parcela $=4,8 \mathrm{~m}^{2}$ (área útil) 
Tabela 12 - Covariâncias e correlaçöes genéticas entre ambientes envolvendo Teor de Óleo ( \% ) 84/85 e Produção de Grãos ( $\mathrm{g} /$ parcela ) 86/87.

\begin{tabular}{lccccr}
\hline Ambiente & COVg (TO,PG) & $V g(P G)$ & $V_{\text {(TO) }}$ & $r_{G}$ (TO,PG) & $r_{F}$ (TO,PG) \\
& & & & & \\
& 84 vs 86 & 84 e 86 & 84 & 84 vs 86 & 84 vs 86 \\
\hline & & & & & \\
1. Anhembi & 64,12 & 14253,4 & 1,92 & 0,38 & 0,22 \\
2. Sertãozinho & 12,98 & 5814,1 & 1,61 & 0,13 & 0,04 \\
3. Esalq & 22,42 & 11253,8 & 1,80 & 0,15 & 0,07 \\
\hline Média 1 e 3 & 43,26 & $11077,4^{1}$ & 1,51 & $0,33^{2}$ & $0,38^{2}$
\end{tabular}

1 PG: Média dos Ambientes 1, 3 e 4.

2 TO médio dos ambientes 1,3 X PG média dos ambientes 1,3 e 4.

Onde: $V g=V_{t}$ (da análise de variância )

Tabela 13 - Covariâncias e correlaçöes genéticas entre ambientes envolvendo Teor de Óleo (\%) $84 / 85$ e Teor de Proteina (\%) $86 / 87$.

\begin{tabular}{|c|c|c|c|c|c|}
\hline \multirow[t]{2}{*}{ Ambiente } & $\operatorname{COVg}(\mathrm{TO}, \mathrm{TP})$ & Vg (TO) & $V g(T P)$ & $r_{G}(T O, T P)$ & $r_{F}(T O, T P)$ \\
\hline & 84 vs 86 & 84 & 86 & 84 vs 86 & 84 vs 86 \\
\hline 1. Anhembi & $-1,47$ & 1,92 & 5,94 & $-0,43$ & $-0,34$ \\
\hline 2. Sertãozinho & $-0,88$ & 1,61 & 5,94 & $-0,28$ & $-0,21$ \\
\hline 3. Esalq & $-0,40$ & 1,80 & 5,94 & $-0,12$ & $-0,09$ \\
\hline Média 1 e 3 & $-0,93$ & 1,51 & 5,94 & $-0,31^{\prime}$ & $-0,23^{1}$ \\
\hline
\end{tabular}

1 Óleo Médio ambientes 1,3 X Proteina ambiente 4

Onde: $V g=V_{t}$ (da análise de variância ) 
Tabela 14 - Covariâncias e correlaçöes genéticas entre ambientes envolvendo Produção de Grãos (g/parcela) 84/85 e Teor de Proteina (\%) 86/87.

\begin{tabular}{|c|c|c|c|c|c|}
\hline Ambiente & $\operatorname{COVg}(P G, T P)$ & $\mathrm{Vg}(\mathrm{PG})$ & $V g(T P)$ & $r_{G}(P G, T P)$ & $r_{F}(P G, T P)$ \\
\hline & 84 vs 86 & 84 e 86 & 86 & 84 vs 86 & 84 vs 86 \\
\hline $\begin{array}{l}\text { 1. Anhembi } \\
\text { 2. Sertãozinho } \\
\text { 3. Esalq }\end{array}$ & $\begin{array}{l}-91,93 \\
-71,23 \\
150,46\end{array}$ & $\begin{array}{r}14253,40 \\
5814,10 \\
11253,80\end{array}$ & $\begin{array}{l}5,94 \\
5,94 \\
5,94\end{array}$ & $\begin{array}{l}-0,31 \\
-0,38 \\
-0,58\end{array}$ & $\begin{array}{l}-0,18 \\
-0,18 \\
-0,27\end{array}$ \\
\hline Média 1 e 3 & $-121,20$ & 11077,40 & 5,94 & $-0,47^{1}$ & $-0,25^{1}$ \\
\hline
\end{tabular}

1 PG média dos ambientes 1,3 e $4 \times$ Proteina ambiente 4

Observação: Ambiente 2 considerado como efeito fixo.

Onde: $V g=V_{t}$ (da análise de variância ) 


\section{APÊNDICES}


Apêndice 1. Variâncias da interação Tratamentos x Ambientes nas análises de variância conjuntas.

$1 \times 2$

$1 \times 3$

13400,80

0,22898

$1 \times 4$

5557,30

9559,40

$2 \times 3$

10487,10

$2 \times 4$

28499,50

$3 \times 4$

$1 \times 2 \times 3$

7903,70

$1 \times 3 \times 4$

9815,10

$1 \times 2 \times 4$

7673,48

$2 \times 3 \times 4$

17153,20

$1 \times 2 \times 3 \times 4$

Onde:

Ambiente $1=$ Anhembi 1984/85

Ambiente 2 = Sertãozinho 1984/85

Ambiente 3 = ESALQ 1984/85

Ambiente $4=$ ESALQ 1986/87 
Apêndice 2 - Correlaçöes genéticas entre ambientes para o caráter produção de grãos ( ao nivel de médias de tratamentos ) ( diagonal superior ), e para o caráter teor de óleo ( diagonal inferior ).

TO \PG

Ambientes

\begin{tabular}{l}
---- \\
\hline 0,87 \\
0,81 \\
----
\end{tabular}

\section{0,06}

-..-‥-

0,93
0,62

$-0,10$

-...-.

3

4

-.---

-...--

Onde:

Ambiente 1 = Anhembi 1984/85

Ambiente 2 = Sertãozinho 1984/85

Ambiente 3 = ESALQ 1984/85

Ambiente $4=$ ESALQ 1986/87 
Apêndice 3 - Médias de duas repetiçסes de 30 genótipos avaliados em quatro ambientes para os caracteres Produçăo de Grăos (PG; Kg/ha); Teor de Óleo (TO; \% ); Teor de Proteína (TP; \% ), e produçăo de proteína (PP; Kg/ha).

\begin{tabular}{|c|c|c|c|c|c|c|c|c|c|}
\hline Genótipos & $\begin{array}{l}\text { Amb1 } \\
P G\end{array}$ & $\begin{array}{l}\text { Amb } 1 \\
\text { TO }\end{array}$ & $\begin{array}{l}\text { Amb2 } \\
\text { PG }\end{array}$ & $\begin{array}{l}\text { Amb2 } \\
\text { To }\end{array}$ & $\begin{array}{l}\text { Amb3 } \\
P G\end{array}$ & $\begin{array}{l}\text { Amb3 } \\
\text { To }\end{array}$ & $\begin{array}{l}\text { Amb4 } \\
\text { PG }\end{array}$ & $\begin{array}{l}\text { Amb4 } \\
\text { TP }\end{array}$ & $\begin{array}{l}\text { Amb4 } \\
\text { PP }\end{array}$ \\
\hline$A \times 53-55$ & 1216.7 & 21.40 & 2541.7 & 19.75 & 2304.2 & 21.00 & 1647.9 & 44.10 & 726.7 \\
\hline ens & 1218.7 & 20.40 & 2685.4 & 20.40 & 1410.4 & 22.80 & 1018.7 & 39.50 & 402.4 \\
\hline SOC 81105 & 2260.4 & 22.75 & 2954.2 & 21.45 & 2364.3 & 21.35 & 1633.3 & 36.70 & 599.4 \\
\hline BR-1 Fosca & 1837.5 & 22.05 & 2329.2 & 23.20 & 2039.6 & 23.90 & 1210.4 & 36.50 & 441.8 \\
\hline BR 5 & 1764.6 & 23.70 & 2481.2 & 22.70 & 2206.2 & 24.20 & 1302.1 & 41.10 & 535.2 \\
\hline PI 322-694 & 910.4 & 19.50 & 2029.2 & 19.00 & 2435.4 & 21.40 & 1345.8 & 40.10 & 539.7 \\
\hline FT - 2 & 1718.7 & 22.65 & 2995.8 & 21.40 & 3043.7 & 22.85 & 1681.2 & 35.00 & 588.4 \\
\hline 60818106 & 1454.2 & 22.00 & 2370.8 & 21.00 & 2229.2 & 21.80 & 1889.6 & 36.80 & 695.4 \\
\hline La 49-10-215 & 1425.0 & 19.50 & 2706.2 & 19.00 & 2347.9 & 21.95 & 1418.7 & 43.05 & 610.7 \\
\hline Biloxi & 1791.7 & 20.70 & 1893.7 & 19.60 & 2308.3 & 21.90 & 1689.6 & 46.20 & 780.6 \\
\hline $50 C 81228$ & 1660.4 & 23.50 & 2856.2 & 20.80 & 2212.5 & 23.60 & 1068.7 & 37.65 & 402.4 \\
\hline BR 80-6 935 & 1843.7 & 22.90 & 2462.5 & 20.25 & 2133.3 & 22.55 & 2016.7 & 37.45 & 755.2 \\
\hline IAS-3 DELTA & 2122.9 & 21.55 & 2847.9 & 20.45 & 2227.1 & 22.95 & 1177.1 & 39.00 & 459.1 \\
\hline Batavian Yellow & 1264.6 & 20.95 & 2383.3 & 19.75 & 2406.2 & 20.60 & 1935.4 & 36.90 & 714.2 \\
\hline FT 79-3408 & 1902.1 & 23.50 & 2708.3 & 22.45 & 3022.9 & 23.80 & 1889.6 & 35.50 & 670.8 \\
\hline Mineira & 2187.5 & 22.75 & 2439.6 & 20.60 & 2589.6 & 24.75 & 2193.7 & 40.40 & 886.2 \\
\hline Dourados & 2002.1 & 22.20 & 2454.2 & 19.70 & 2687.5 & 21.80 & 1845.8 & 40.05 & 739.2 \\
\hline BR-80-14887 & 1670.8 & 18.40 & 2770.8 & 17.35 & 1956.2 & 19.05 & 1058.3 & 39.40 & 416.9 \\
\hline Sta. Rosa Verde & 1900.0 & 23.45 & 2379.2 & 22.40 & 2427.1 & 23.65 & 1179.2 & 40.15 & 473.4 \\
\hline Gaúcha & 1710.4 & 19.85 & 2585.4 & 20.05 & 2141.7 & 21.35 & 1168.7 & 45.40 & 530.6 \\
\hline Hampton & 1450.0 & 23.60 & 2662.5 & 23.05 & 2218.7 & 25.00 & 1745.8 & 42.80 & 747.2 \\
\hline Hardee & 1256.2 & 23.50 & 2670.8 & 23.60 & 2754.2 & 24.55 & 1091.7 & 41.15 & 449.2 \\
\hline GO 81-11081 & 1808.3 & 21.65 & 1983.3 & 21.35 & 2839.6 & 23.30 & 1693.7 & 36.85 & 624.1 \\
\hline FT 10 Princesa & 1520.8 & 20.80 & 2791.7 & 21.60 & 2933.3 & 23.50 & 1141.7 & 42.70 & 487.5 \\
\hline IAC - 2 & 2141.7 & 23.40 & 2458.3 & 21.50 & 2247.9 & 25.50 & 1643.7 & 40.60 & 667.3 \\
\hline IAC - 3 & 1806.2 & 22.65 & 2254.2 & 21.55 & 3060.4 & 23.75 & 1410.4 & 37.10 & 523.2 \\
\hline NovaSantaRosa & 1966.7 & 23.50 & 2502.1 & 21.40 & 2783.3 & 23.95 & 1410.4 & 37.20 & 524.7 \\
\hline São Luiz & 1958.3 & 21.90 & 2643.8 & 21.45 & 3062.5 & 24.15 & 1792.9 & 36.15 & 648.1 \\
\hline Yelnanda & 1814.6 & 20.90 & 2647.9 & 20.80 & 2554.2 & 23.40 & 1229.2 & 41.45 & 509.5 \\
\hline IAC - 11 & 2483.3 & 21.95 & 2208.3 & 21.85 & 2666.7 & 23.50 & 2879.2 & 41.65 & 1199.2 \\
\hline Davis & 1427.0 & 22,27 & 2758.0 & 21.84 & 1989.0 & 23,51 & 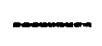 & - & - \\
\hline Bossier & 1575.0 & 23.13 & 2827.0 & 22.50 & 2992.0 & 23.94 & 2322.8 & 41,55 & 965.1 \\
\hline IAC 12 & 2245.8 & 23.11 & 2637.4 & 22.44 & 2737.4 & 22.70 & 2496,9 & 42,20 & 1058,7 \\
\hline IAC 10 & 2218.7 & 22.50 & 2368.7 & 22.62 & 2735.4 & 24.11 & - & - & $\cdots$ \\
\hline S-573 & - & - & - & - & $\longrightarrow$ & - & 1414,6 & 43,20 & 611,1 \\
\hline IAC Foscarin 31 & سمس & - & $\longrightarrow$ & - & $\longrightarrow$ & - & 1579,1 & 39,25 & 619,8 \\
\hline S-574 & $\longrightarrow$ & - & $\longrightarrow$ & - & - & - & 952,1 & 46,65 & 444,1 \\
\hline IAC-8 & 1858.3 & 22.35 & 2639.5 & 20.90 & 3162.4 & 23.60 & 2993,7 & 45,85 & 1372,6 \\
\hline Média Geral & 1735.6 & 21.92 & 2523.3 & 20.98 & 2453.8 & 22.93 & 1547.1 & 39.62 & 611,61 \\
\hline D.M.s. & 1262.9 & 2.22 & 996.53 & 3.25 & 1920.8 & 3.31 & & & \\
\hline
\end{tabular}

DMS = Diferença Minima Significativa (Tukey à 5\%). Dados dos Ambientes 1, 2 e 3 obtidos de SOLDINI ( 1993 ). 